\title{
De morcegos e caveiras a cruzes e livros: a representação da morte nos cemitérios cariocas do século XIX lestudo de identidade e mobilidade sociais)
}

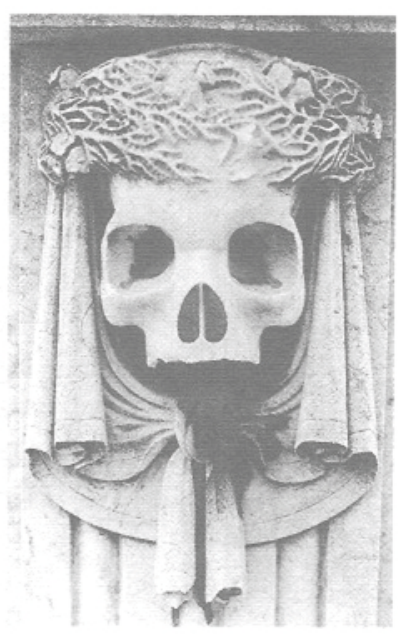

Tania Andrade Lima

Universidade Estácio de Sá

Rio de Janeiro

Introdução

No âmbito de um projeto que vem investigando, do ponto de vista arqueológico, a emergência de um modo de vida burguês no Rio de Janeiro do século XIX, antecedendo a instalação da burguesia propriamente dita no país (Queirós, 1978), foram pesquisados os espaços funerários implantados nessa cidade a partir de meados do século passado!.

Considerando que os espaços destinados aos mortos em uma sociedade refletem especularmente o mundo dos vivos, sendo ambos regidos pela mesma lógica de organização, os cemitérios foram entendidos como um lugar de reprodução simbólica do universo social, e, nessa condição, como um campo privilegiado para a análise do processo de implantação e consolidação dos valores burgueses na sociedade carioca do século passado. Por essa razão, ao lado de contextos domésticos e produtivos, urbanos e rurais, os espaços funerários foram também incorporados como objeto de investigação ao projeto em desenvolvimento.

Por sua vez, vistos enquanto sítios arqueológicos, os cemitérios constituem um domínio excepcional para a observação e análise, a partir da cultura material, de fenômenos de dinâmica cultural e mudança social. Uma vez
1. Entende-se aqui por modo de vida burguês as formas de comportamento decorrentes da ideologia de privatizacào que se consolidou na Europa ao longo do século XIX, paralelamente aos avanços da industrialização, valorizando o individualismo, as fronteiras entre o público e o privado. o universo familiar e a ritualizaçào da vida cotidiana, a acumulaçào de capital (tanto real quanto simbólico), os critérios de "respeitabilidade", a fetichizaçào do consumo e a ascensào social. 
erigidas, as sepulturas (e todo o aparato que as acompanha) permanecem, na sua quase totalidade, em suas primitivas posições, sem que ocorram alterações significativas no contexto original. Isto propicia uma configuração ímpar para a investigação arqueológica, pelas excelentes possibilidades que oferece, em termos de controle dos dados.

Os jazigos constituem artefatos datáveis com precisão, já que nas lápides tumulares ficam em geral impressas as datas de nascimento e falecimento dos indivíduos que aí foram enterrados. Essas datas, salvo em casos de traslados, como ocorre com os ossários, por exemplo, ou em casos de reformas posteriores, coincidem em geral com a época do sepultamento. Outros elementos gráficos e iconográficos apostos às sepulturas (nome do morto, ascendência e/ou descendência familiar, profissão, títulos, termos utilizados em dedicatórias, memoriais, louvações, etc., bem como a própria estrutura desses escritos; adornos, esculpidos nas lajes ou sobrepostos a elas; suas variações através do tempo e sua distribuição espacial) fornecem um campo vasto e fecundo para a pesquisa.

O universo funerário vem sendo consideravelmente estudado no âmbito das Ciências Sociais, em especial pela Antropologia, bem como no da História Social. Trabalhos como os de Tenenti (1952), Gorer (1965), Vovelle (1970, 1974, 1978, 1983, 1987, 1993), Ariès (1977, 1989, 1990) e Urbain (1978) tornaram-se clássicos da literatura especializada, que vem incorporando um número crescente de produções (Curl, 1972, 1980; Stannard, 1977; Farrell, 1980; Ragon, 1981; Humphreys \& King, 1981; Penny, 1981; Taylor, 1980 e 1983; Gnoli \& Vernant, 1982; Houlbrooke, 1989; Huntington, 1992, entre muitos outros).

Seminários e simpósios internacionais sobre o tema estão se tornando freqüentes (Death, ritual and bereavement, organizado pela Social History Society/Londres, 1987; Una Arquitectura para la muerte, № Encuentro Internacional sobre los Cementerios Contemporaneos, Sevilha, 19911, assim como exposições em museus: The at of death: visual culture in the English death ritual, mostra organizada pelo Victoria and Albert Museum, em 1992 (ver Llewllyn, 1992).

Estudos de cultura material vêm privilegiando particularmente pesquisas em cemitérios históricos, envolvendo ou não escavações, e estão se multiplicando as monografias sobre o assunto, em especial nos Estados Unidos, Canadá e Inglaterra (Anderson, 1993; Bender, 1988; Brock, 1991; Brooks, 1989; Brown, 1992 a e b; Clark, 1987; Coates, 1987; Combs, 1986; Crowell, 1981; Corrucini, 1982; Costello, 1987; Deetz, 1977; Deetz \& Dethlefsen, 1978; Dethlefsen, 1981; Frascari, 1981; Gittings, 1988; Hall, 1986; Hannon, 1983; Jeane, 1989; Jordan, 1980; Kjolbye-Biddle, 1976; Lanphear, 1990; Little et al., 1992; McGuire, 1988; Milbauer, 1989; Osborne, 1974; Owsley et al., 1987; Parrington, 1987; Patterson, 1986; Pearson, 1982; Pocins, 1986; Richardson, 1993; Ridlen, 1983; Rodwell, 1989; Sexton, 1991; Slater, 1987; Stone, 1991; Stone \& Russel, 1986; Trask, 1978; Trask \& McNabb, 1986; Watters, 1987; Wurst, 1991, entre outros). No Brasil, o investimento no universo da morte ainda é
consideravelmente tímido, não obstante a excelência de contribuições como as 
de Valladares (1972), Martins, org. (1983), e Reis (1991). Seminários, como A morte e os mortos na sociedade brasileira, realizados na Universidade de São Paulo; estudos monográficos (Loureiro, 1977; Meihy \& Levine, 1987; Campos, 1987 e 1988, entre outros), teses de doutoramento, quer defendidas no exterior (Rodrigues, 1983), no país (Borges, 19911, ou ainda em andamento, a par de dissertações de mestrado (Guedes, 1986), atestam a crescente vitalidade das pesquisas no campo funerário.

A arqueologia tem aí um importante campo de atuação e os trabalhos desenvolvidos em outros países vêm demonstrando as possibilidades que ele oferece para a comprensão de sistemas sócio-culturais extintos. Pelo seu trato direto com a cultura material, a disciplina qualifica-se notavelmente para esse tipo de investigação, sendo capaz de somar novos conhecimentos aos já produzidos a partir dos registros documentais.

Esta pesquisa, considerando a ruptura do império escravista, na década de 80 , e a emergência de uma república progressivamente capitalista, voltou-se para a verificação de prováveis mudanças no imaginário coletivo sobre a morte, nos cemitérios do Rio de Janeiro, provocadas pelo rompimento da ordem escravocrata. Conforme assinalou Carvalho (1990:101, "a manipulação do imaginário social é particularmente importante em momentos de mudança política e social, em momentos de redefinição de identidades coletivas".

Assim sendo, quer como resultado de tensões internas, operando em um plano inconsciente, quer como produto de ações política e ideologicamente determinadas e portanto conscientes, assumiu-se a priori que a reordenação econômica, política, social e ideológica do sistema, ao final do século, implicou um fenômeno de mudança nas representações da morte. A pesquisa foi conduzida no sentido de se investigar não apenas a natureza dessa mudança, mas sobretudo os mecanismos subjacentes que a determinaram.

\section{A implantação de cemitérios no Rio de Janeiro}

A sucessão de surtos epidêmicos, responsáveis por milhares de mortes, determinou, no âmbito da ideologia de sanitarização que espraiou no século passado, uma série de transformações nas políticas sanitárias e nos hábitos de higiene, pública e privada. Entre outros possíveis focos, cadáveres passaram a ser considerados como perigosos transmissores de doenças, evitando-se o contato direto com eles. Os sepultamentos ad sanctos, feitos até então em terrenos adjacentes às igrejas, começaram a ser combatidos como prováveis fontes de infecções e epidemias, estabelecendo-se com força crescente uma relação de causa e efeito entre cadáveres e proliferação de doenças.

Este movimento no sentido de isolar os vivos dos mortos se inscreve no contexto mais amplo da ideologia de controle que, estendendo progressivamente seus dispositivos ao longo dos séculos XVII e XVIII, se intensificou no século XIX, multiplicando-se, como assinala Foucault (1983:184), por todo o corpo social, formando o que se poderia chamar de sociedade disciplinar. 
Ao lado de outros aparelhos disciplinares, como prisões, conventos, manicômios, estabelecimentos de ensino, quartéis, fortalezas, hospitais, que têm no isolamento e na meticulosa organização e repartição do espaço, no princípio do quadriculamento individualizante, como diz Foucault, os fundamentos para melhor observar, controlar e dominar, podem ser também incluídos os cemitérios.

Se aqueles espaços passam a ser rigorosamente definidos, delimitados (cercas, grades, muros, muralhas, portões, fossos, etc.) e repartidos em unidades cada vez menores, para "satisfazer a necessidade de vigiar, de romper as comunicações perigosas" (op. cit.:132) entre os vivos, trata-se agora de impedir a todo custo qualquer forma de comunicação perigosa com os mortos, ou seja, o contato direto, a proximidade física (Foucault, 1986:90). Ao lado dos loucos, doentes e condenados, os mortos são também excluídos, banidos do espaço urbano para áreas periféricas, igualmente enquadrados e, por extensão, controlados.

O espaço funerário é assim cercado, bem delimitado, murado, gradeado las normas definem até a altura dos muros e das grades, sempre bem superiores à estatura média de um indivíduo, de forma a desestimular a sua transposição). É cuidadosamente repartido, quadriculado (aléias, quadras, etc.), geometricamente alinhado, ordenado, de modo a permitir a observação, a vigilância, o controle. A circulação é bem definida e visível. Em cada sepultura há números, nomes e datas que individualizam os mortos, permitindo a sua imediata classificação e localização, tanto no espaço quanto na escala social. Esses dados são registrados em livros sujeitos a toda sorte de inspeções, ocorrendo severas punições em casos de irregularidades.

O cemitério torna-se uma cidade fechada, ou uma instituição total (adaptando-se aqui o conceito, tal como proposto por Goffman, 1974:15-19), sujeita a regras rigorosas de funcionamento. Um rígido horário de abertura/fechamento regula a entrada (dia)/saída (noite) e, portanto, o contato entre vivos/mortos. Este só é permitido à luz do sol, onde reina a "ordem", a limpeza, a higiene (os vivos), já que ao cair das trevas (domínio dos mortos, da imundicie e da "desordem", onde proliferam animais asquerosos) perde-se a visibilidade, e com ela as possibilidades de controle (objetivo/subjetivo). É aí que se introduz o medo, o "grande medo da morte", de que nos fala Ariès (1990:440), como o medo dos loucos, dos infectados, dos marginais, de todos aqueles que estão além das fronteiras, dos limites, das regras.

Em meados do século XIX, o Rio de Janeiro era uma cidade exposta a toda sorte de contágios e assolada por uma sucessão de epidemias de cólera, febre amarela, varíola, em meio à mais absoluta falta de higiene, com todos os tipos de dejetos (inclusive cadáveres) lançados diretamente nas praias e nas ruas, sem esgotos sanitários e permanentemente bafejada por "miasmas pútridos". A criação de cemitérios extramuros foi se tornando um imperativo cada vez mais forte, sobretudo nas áreas urbanas, reforçado pelo problema de superlotação dos espaços funerários adjacentes às igrejas. Os surtos epidêmicos que vitimaram grande parte da população carioca, entre 1838 e 1855, contribuiram para mobilizar ainda mais fortemente o poder público para as questões relacionadas à higiene e saúde. Finalmente, em 5 de setembro de 
1850, o decreto $n^{\circ} 583$, assinado pelo Visconde de Mont'Alegre, determinou o estabelecimento de cemitérios públicos nos subúrbios do Rio de Janeiro, com o governo reservando-se o direito de permitir a criação de cemitérios particulares, nas condições que julgasse convenientes.

A Santa Casa da Misericórdia, fundada em 1.582 por José de Anchieta, com a finalidade de prestar assistência médica aos tripulantes de navios atacados pela peste, à época, tomou a si a tarefa de sepultátos, naquela ocasião, em um terreno ao lado do seu tosco hospital. Desde então, a instituição passou a se dedicar à missão de prestar atendimento médico à população em geral, particularmente aos desfavorecidos: pobres, desamparados, marginais de toda sorte, além de vítimas de epidemias, combates, etc., encarregando-se ainda do seu sepultamento. A estes somavam-se protestantes, judeus, muçulmanos, negros, índios e condenados, para quem era vedado o sepultamento ad sanctos, restando apenas a assistência prestada pela Santa Casa. Algumas irmandades religiosas e ordens terceiras, que inumavam os segmentos mais altos da sociedade nos terrenos adjacentes às igrejas, ocupavam-se, em alguns casos, do enterro de escravos, porém era bastante comum seus corpos serem apenas jogados à beira de caminhos e de praias.

Em meados do século XIX, a situação do Hospital Geral da Prata de Santa Luzia, pertencente à Santa Casa, tornara-se insustentável com o cemitério ao seu lado. Os médicos protestavam violentamente contra a proximidade dos cadáveres, tanto de mendigos quanto de irmãos da Misericórdia, em número crescente, comprometendo a salubridade não só do hospital, como também da própria cidade. Urgia disciplinar ambos os espaços, eliminando a promiscuidade em que se encontravam e instalando as necessárias estratégias de controle.

Em 1838, assumiu a Provedoria da Santa Casa José Clemente Pereira que, ocupando altos cargos no governo, acumulava então considerável poder político. Como provedor, defendeu ferreamente os interesses da instituição, vindo a ganhar mais tarde a concessão dos serviços públicos funerários por 50 anos (decreto imperial no 843, de 18 de outubro de 1851) e implantando um monopólio que se mantém até os nossos dias, no Rio de Janeiro, graças às sucessivas renovações do privilégio.

Em 1839, em virtude do estado de "calamidade pública", segundo suas próprias palavras, em que se encontrava a Santa Casa e, por extensão, a cidade, conseguiu as devidas aprovações e fez inaugurar o seu primeiro cemitério público extramuros, o Campo Santo da Misericórdia, situado na Ponta do Calafate, no Caju, lá sepultando uma escrava e cerca de 300 vítimas da epidemia de cólera. Em 1840, mandou fechar para sempre os jazigos e catacumbas do hospital, ampliando, com a aquisição de novos terrenos, o primitivo núcleo do Campo Santo, transformado, em 1851, no Cemitério de São Francisco Xavier, também conhecido como Cemitério do Caju, através do decreto imperial no 842, de 16 de outubro. Este mesmo instrumento determinou a instalação de uma nova necrópole no Brequó (atual Zona Sul, Botafogo), só inaugurada em 1852: o Cemitério São João Batista (Vasconcellos, 1878).

A par dos cemitérios e do hospital, a Santa Casa administrava ainda - Hospício D. Pedro II, a Casa dos Expostos, o Recolhimento das Órfãs e 
Desvalidas, a Enfermaria, assumindo a seu encargo, portanto, além dos mortos, os loucos, alienados, tuberculosos, variolosos, enfermos de toda natureza, órfãos, mendigos, escravos, ou seja, todos os segmentos potencialmente perigosos, que precisavam ser disciplinados, ordenados, controlados. Acumulou à essa época um considerável poder, ao administrar essa diversidade de instituições, assegurando à sociedade que a sustentou o controle que se fazia necessário para a sua organização.

Por outro lado, as irmandades religiosas que estavam igualmente com as igrejas abarrotadas de cadáveres, temendo inclusive a perda das esmolas dos enterros para os seus cofres, começaram a pressionar fortemente a opinião e o poder públicos contra os privilégios acumulados pela Santa Casa, no processo de secularização dos cemitérios.

Desejosas de obter concessão para abertura de cemitérios particulares, religiosos, expressavam seu repúdio em manifestos aos jornais, como o da Ordem do Carmo, publicado no Jornal do Comércio, em 1852, onde foram utilizadas expressões como "repugnância (...) das diversas Ordens Terceiras por não quererem ficar ungidas à Santa Casa". Pretendiam "ficar fora do domínio, inspeção e chaves da Santa Casa da Misericórdia, empresária dos enterramentos e pompas fúnebres", recusando-se a "enterrar seus irmãos, muitos dos quais são indivíduos importantes na sociedade brasileira (...), entre os escravos e os mendigos e padecentes"

A primeira irmandade a conseguir a aprovação do Governo Imperial foi a Venerável Ordem Terceira dos Mínimos de São Francisco de Paula que, em 1849, instalou o primeiro cemitério particular extramuros da cidade, no então Catumbi Grande. Em 1857, e somente após o falecimento do Provedor José Clemente, a Santa Casa da Misericórdia desmembrou parte de seus terrenos no Caju para a instalação de mais dois cemitérios particulares: o da Venerável Ordem Terceira de Nossa Senhora do Monte do Carmo e o da Venerável Ordem Terceira de São Francisco da Penitência.

Foram desta forma colocados à disposição da população carioca, em meados do século passado, tanto cemitérios religiosos (particulares), quanto seculares (públicos). Os primeiros, elitistas, destinados exclusivamente aos membros das irmandades, em grande parte representantes das classes mais abastadas, cuidavam para que tosse mantido o seu perfil religioso. Conforme determinação do artigo 6o do regulamento do Cemitério São Francisco de Paula, aprovado quando da sua fundação, "o plano e prospecto (dos monumentos) devem ser em modo que não apareçam símbolos ou alusões profanas, em desarmonia com o tipo religioso de tais monumentos". Mais ainda, empenhavam-se no apuro estético dos seus espaços funerários, visando com isto atrair para seus quadros a nata do império, para desta forma assegurar à Ordem maior prestígio e poder.

Já os últimos, secularizados, em princípio abertos a indivíduos de qualquer credo ou raça, eram francamente liberais, exigindo apenas, em seus estatutos, que as incrições nas lápides não ofendessem nem a moral, nem as leis. O seu traçado banal, somado a essa liberdade de expressão, atestam 0 descompromisso com a estética e a qualidade artística, deixadas ao arbítrio de cada um. 
Em 1851, no espírito desse movimento de higienização e controle que tomou conta da sociedade em meados do século, foi finalmente criada a Junta Central de Higiene Pública. Destinada a fiscalizar o exercício da Medicina e a inspecionar as condições sanitárias de locais passiveis de comprometerem a saúde pública lentre eles os cemitérios, além de hospitais, prisões, estabelecimentos de ensino, etc.), inaugurou uma nova etapa na organização da saúde pública no Brasil (Machado, 1978:246).

Os cemitérios analisados

Foram selecionados para estudo os cinco principais cemitérios da cidade, inaugurados em meados do século passado, todos situados atualmente na zona urbana do Rio de Janeiro. Dois são seculares, administrados pela Santa Casa da Misericórdia (Cemitério São João Batista, em Botafogo; Cemitério de São Francisco Xavier, no Caju) e três pertencem à ordens religiosas (Cemitério da Ordem Terceira dos Mínimos de São Francisco de Paula, no Catumbi; Cemitério da Ordem de Nossa Senhora do Carmo e Cemitério da Ordem de São Francisco da Penitência, ambos no Caju).

Apenas dois foram trabalhados sistematicamente: o Cemitério da Venerável Ordem Terceira dos Mínimos de São Francisco de Paula, conhecido como Cemitério do Catumbi, selecionado como modelo de cemitério religioso; e o Cemitério de São João Batista, como modelo de cemitério secular. Os demais foram avaliados à luz dos dados aí levantados, atuando como confirmadores dos resultados e interpretações neles obtidos. Não foi incluído neste estudo o Cemitério dos Ingleses, na Gamboa, na verdade o primeiro espaço funerário extramuros implantado na cidade, em 1810, por especial concessão do príncipe regente. Destinado à época ao sepultamento de protestantes ingleses, abrigou estrangeiros em geral, de diferentes nacionalidades e credos religiosos, não-católicos: alemães, suiços, dinamarqueses, franceses, etc. Com signos e alegorias próprios, seu estudó escaparia aos objetivos desta investigação.

O Cemitério da Venerável Ordem Terceira dos Mínimos de São Francisco de Paula ou Cemitério do Catumbi.

Em meados do século XIX, com a superlotação do espaço adjacente à Igreja de São Francisco de Paula, destinado aos mortos, e com a reordenação das questões relativas à higiene e saúde públicas anteriormente mencionadas, a administração da Ordem Terceira decidiu partir, mais exatamente em 1845, segundo Vieira Fazenda (1921:352), para a implantação de um cemitério extramuros. Iniciativa pioneira entre as ordens religiosas, considerando que até então só havia o cemitério secular do Campo Santo da Misericórdia, mantido pela Santa Casa, a Irmandade obteve, em 1849, a aprovação do governo imperial para a sua instalação.

Nesse mesmo ano já havia sido negociada para esta finalidade uma chácara, situada à Rua Catumbi Grande, e elaborada a planta, de acordo com as disposições da Imperial Academia de Medicina. Em 1850 foi inaugurado o 
cemitério, com o traslado de vários despojos de irmãos da Ordem que lotavam as catacumbas da lgreja e ainda o sepultamento de cerca de 3.000 vítimas da epidemia de febre amarela, não pertencentes à congregação, a pedido do governo imperial, tendo em vista que era a única que então possuía "campo santo extramuros para seus mortos" (Duprat, 1897). Na planta original podiam ser distinguidos três níveis, de acordo com a topografia acidentada do terreno:

- o da entrada, ao nível da rua; plano, porém sujeito a inundações por ocasião de chuvas fortes.

- uma vertente, elevando-se gradativamente até o sopé dos morros.

- terrenos variados, compreendendo uma várzea irrigada pelas águas de uma fonte natural, alguns montículos e um pequeno vale.

O primeiro, baixo, alagadiço, requerendo aterros e plantio de arvoredos, foi destinado à colocação dos ossários, por se tratar de sepultamentos secundários. Estando já consumado o processo de decomposição, não ofereceriam maiores riscos para a disseminação de bactérias e proliferação de doenças. Colocados em geral em urnas, sobre pedestais elevados, os ossos ficavam a salvo das inundações, adequando-se portanto a sua função à topografia e condições de drenagem do terreno.

Esses ossários ficavam elegantemente dispostos ao longo da alameda central, que cortava toda a parte baixa, encontrando em seu final um eixo transversal, situado entre o primeiro e o segundo nível, em um plano ligeiramente elevado. Este patamar foi selecionado para aí ser implantado o eixo monumental, reservado à colocação dos mausoléus, de tal forma que da entrada se avistava a alameda de ossários e, ao fundo, no alto e em destaque, os grandes monumentos fúnebres. Trata-se de um traçado urbanístico de excelente qualidade, porém na documentação consultada da Ordem não foi possível obter referências quanto ao seu autor.

O segundo nível, inclinado, foi considerado ideal para a colocação dos túmulos, por se tratar de área extensa e bem drenada, além de arejada. À época foi muito discutida a direção dos ventos no local, considerando-se a preocupação dominante com miasmas e exalações. Sua topografia, comparada então com a do Père Lachaise, em Paris, foi considerada excelente para o cemitério.

O terceiro, que pela irregularidade do terreno exigiria beneficiamentos dispendiosos e obras de grande vulto, foi reservado para futuras ampliações, o que mais tarde efetivamente veio a ocorrer.

O Cemitério de São Francisco de Paula foi inquestionavelmente o mais importante do império, tendo sido aí sepultada grande parte da nobreza (marqueses, duques, condes, viscondes, barões em profusão), conselheiros, comendadores, altas patentes militares e os segmentos mais abastados da sociedade à época.

\section{Cemitério São João Batista}

Fundado através do já referido decreto imperial no 842, de 16 de outubro de 1851, o Cemitério São João Batista funcionou provisoriamente em terrenos do Hospício D. Pedro II, em virtude de discordâncias entre o Provedor 
da Misericórdia e o Ministério dos Negócios do Império, quanto ao local mais adequado para a sua instalação.

Superado o impasse e aprovada a proposta da Santa Casa, o cemitério foi inaugurado oficialmente em 4 de dezembro de 1852, nos terrenos de uma chácara adquirida para esta finalidade, em Botafogo, após a realização de obras de aterro e drenagem. Em 1857, foi consideravelmente ampliado com a compra de novos terrenos, totalizando uma ampla área de formato trapezoidal, que se estende pela vertente do Morro de São João.

Com um traçado urbanístico convencional, a área foi dividida em quadras regulares, centradas por um cruzeiro, distribuídas em uma parte plana, ao nível da rua, e em dois lances de terra aplanada, no início da encosta do morro. Sua sepultura mais antiga data de 1858, embora os ossários abriguem despojos de anos anteriores, trasladados das catacumbas das igrejas.

Os ossários do século XIX, em quantidade muito superior à do Cemitério de São Francisco de Paula, foram dispostos ao longo da alameda central, defronte à entrada, e no contorno das quadras, em carreira única, dupla ou tripla, conforme o caso.

Os poucos mausoléus da época foram colocados à direita da entrada, de costas para a rua, em local de baixa visibilidade para o visitante à chegada, sem qualquer imponência. Outros poucos, mais próximos da virada do século, foram implantados na parte alta do terreno, à esquerda, o que os torna mais visíveis, porém sem grande impacto visual, nem de longe alcançando a magnitude da ala monumental do Catumbi.

Os túmulos, à semelhança daquele cemitério, foram distribuídos nos patamares da encosta, preenchendo a porção interna das quadras. A implantação dessas primeiras sepulturas em planos inclinados parece ter sido determinada pelas boas possibilidades de escoamento de águas pluviais, evitando-se que jazigos contendo sepultamentos primários, em processo de decomposição, ficassem alagados, aumentando os riscos de contaminação.

Para este cemitério convergiram as preferências das classes dominantes do período republicano, o que foi relegando progressivamente o Całumbi a uma condição secundária. Se lá foram sepultados os segmentos mais expressivos do império, no São João Batista encontra-se a nata da república: presidentes, políticos de projeção, chefes militares, a alta burguesia etc.

Metodologia de trabalho

Para fins da investigação proposta, ou seja, a constatação de uma possivel mudança na representação da morte na transição do império escravista para a república progressivamente capitalista, cada cemitério foi entendido como um sítio arqueológico, sendo os jazigos considerados como artefatos e, nessa condição, reunindo uma série de atributos. Dentre estes, foram destacadas, privilegiadas $e$ isoladas para análise, tendo em vista os fins propostos, não apenas a forma e a função (sempre estreitamente associadas), mas sobretudo as representações iconográficas. 
A pesquisa de campo

Na abordagem de cada espaço funerário pesquisado impôs-se inicialmente um reconhecimento do terreno, em termos da sua delimitação e topografia, a análise da sua implantação nesse espaço físico e do seu traçado urbanístico.

Considerando a feição atual aparentemente caótica dos cemitérios, que coloca lado a lado sepulturas do século XIX e da década em curso, tornouse fundamental entender a lógica que rege a sua ocupação. Para tanto, foi necessário suprimir imaginariamente do espaço funerário os jazigos do século $X X$, de modo a se "visualizar", tanto quanto possível, apenas os do século passado. Este procedimento permitiu obter rapidamente um perfil da época em questão, de tal forma que, ao ingressar em cemitérios ainda não estudados, o observador percebe, em poucos minutos, através de uma rápida avaliação visual, a sua disposição original no século XIX.

Nos dois cemitérios selecionados como modelos, para fins analíticos, procedeu-se em primeiro lugar a uma classificação dos diferentes tipos de jazigos (ou sepulturas) existentes. Esses dois termos são aqui utilizados de modo indiferenciado, significando o local onde foram inumados um ou mais indivíduos, independentemente das condições da inumação e do tipo de edificação erigido sobre ela. Assim sendo, foram reconhecidas três categorias de jazigos ou sepulturas: túmulos, ossários e mausoléus.

- por túmulo entende-se o jazigo onde foram realizados um ou mais sepultamentos primários, ou seja, onde foram dispostos os corpos articulados de um ou mais indivíduos, em posição distendida, normalmente em caixões. Do ponto de vista da forma, essas sepulturas são alongadas, de modo a comportar um corpo deitado.

- por ossário entende-se o jazigo onde foram realizados um ou mais sepultamentos secundários, ou seja, onde foram dispostos os ossos desarticulados de um ou mais indivíduos, após o processo da sua decomposição, normalmente em urnas. Do ponto de vista da forma, essas sepulturas são estreitas e altas, não comportando o corpo humano em posição distendida.

- por mausoléu entende-se uma terceira categoria, híbrida, que comporta tanto sepultamentos primários quanto secundários, em caixões e em urnas, de vários indivíduos, pertencentes a uma mesma família, grupo, organização ou entidade civil ou religiosa. Do ponto de vista da forma, trata-se de uma edificação de grande porte, de caráter monumental, suntuosa. Duas sub-categorias foram reconhecidas entre os mausoléus: as capelas, caso em que essas edificações apresentam uma arquitetura eminentemente religiosa, cristã , reproduzindo uma pequena igreja, e os monumentos, onde inexiste este tipo de vinculação.

Uma vez classificados e definidos os diferentes tipos de jázigos, procedeu-se a um minucioso levantamento gráfico e iconográfico das sepulturas, no âmbito de cada uma das categorias acima referidas. Por se tratar de um universo bastante amplo, envolvendo milhares de unidades funerárias, foi necessário sistematizar a coleta de dados, de modo a agilizar a tarefa de descrição e registro. 
Dois tipos de signos foram reconhecidos: os verbais (epigrafia tumular) e os não-verbais (elementos escultóricos e arquitetônicos). Para cada um deles foi concebida uma sigla alfa-numérica, o que permitiu sintetizar em apenas algumas letras um grande número de signos, obtendo-se assim um máximo de informação, com um esforço tanto quanto possivel minimizado.

O levantamento, limitado ao período compreendido entre o ano da inauguração do cemitério estudado e a virada do século (1903), foi feito jazigo a jazigo, seguindo-se a numeração atribuída a cada um deles pela administração do local, e desta forma avaliando-se a ocupação progressiva do espaço. Atenção especial foi dada às datas impressas nas lápides, registradas juntamente com os signos verbais e não verbais.

Diversas sepulturas não apresentaram qualquer referência cronológica, o que criou dificuldades para sua datação. Esta omissão exigiu, em laboratório; a elaboração de uma estratégia destinada a impedir a perda dos dados iconográficos aí existentes, fundamentais para se evitar a distorção da amostra. Já as sepulturas que sofreram alterações posteriores decorrentes de reformas, claramente perceptíveis, foram desprezadas no levantamento.

As três categorias de sepulturas reconhecidas foram plotadas em uma planta esquematizada do local, o que permitiu visualizar sua distribuição no espaço funerário, bem como as possíveis relações espaciais entre elas.

Os signos verbais, embora levantados, não foram trabalhados para os fins desta pesquisa e apenas os não verbais foram objeto da presente investigação, tendo sido classificados como signos antropomorfos, zoomortos, fitomorfos, signos ligados ao fogo, de nobreza ou distinção social e representações de objetos. Comportando variações e sub-variações, foram assim sintetizados e codificados:

\section{1 - Signos Antropomorfos}

I - Figura de anjo

1 - Figura de criança

III - Figura feminina

IV - Figura masculina

$V$ - Crânio
A - Em pé

B - Sentada

C - Ajoelhada

D - Em vôo

E - Face

$F$ - Büsto

G-Cena

$\mathrm{H}$ - Militar

I - Isolado

J - c/ tíbias cruzadas

$\mathrm{K}-\mathrm{C} /$ panejamento

$\mathrm{L}-\mathrm{c} / \mathrm{criança} \mathrm{ao} \mathrm{colo}$ $a-c /$ tocha para cima

b- c/ tocha para baixo

$c-c /$ coroa de flores

d - c/ mãos cruzadas sobre peito

e - c/ livro

$f-c /$ cruz

$\mathrm{g}-\mathrm{c} /$ cálice

$h-c /$ trombeta

i. - c/ fita

j - c/ instrumento agrícola

$k-c /$ serpente

l - c/ bastão alado e serpente

$m-c /$ âncora

$\mathrm{n}$ - orando

o- refletindo

$p$ - cariátides

$q$ - associado à urna

$r-c /$ foice

$\mathrm{s}-\mathrm{c} /$ pergaminho

$\dagger-c /$ cornucópia de frutos 
$u-c /$ estrela na cabeça

$v-c /$ coluna

$x$ - sobre almofada

$z-c /$ pomba

2 - Signos Zoomorfos

$\begin{array}{lll}\text { I - Coruja } & \text { A - Isolado } & \text { a - uma volta } \\ \text { II - Morcego } & \text { B - Suporte } & \text { b- duas voltas } \\ \text { III - Serpente } & \text { C - Asa } & \text { C - emaranhada } \\ \text { IV - Pata de leão } & \text { D - Engolindo o rabo } & \\ \text { V - Abelha } & \text { E - Em alça } & \\ \text { VI - Pombo } & \text { F - Em bastão alado } & \\ \text { VII - Águia } & \text { G - Em figura antropomorfa } \\ & \text { H - Em tocha } & \end{array}$

3 - Signos Fitomorfos
I - Flor
A - Isolado
a - com fita
II - Folha
B - Ramalhete
III - Fruto
C - Coroa
IV - Em moldura
D - Cornucópia

4 - Signos ligados ao fogo

II - Lamparina
II - Tocha
III - Tocheiro
IV - Chama

A - Isolado

B - Para cima

C - Para baixo

D - Horizontal

E - Saindo de urna
a - isolado
b - cruzadas entre si
c - cruzada por foice
d - cruzada por cruz
e - c/ coroa, flor e folha
$f-c /$ fita
$g-c /$ serpente
h - c/ pata de leão

5 - Signos de Nobreza ou Distinção Social

I - Brasão
II - Coroa
III - Maçônico
IV - Título/Comenda
V - Arma

6 - Objetos
I - Urna
II - Ampulheta
A - Isolado
B - Forma de vaso
$a-c /$ fita
C - Forma quadrangular
III - Cruz
D Forma piramidal
$b-c /$ flor
IV - Crucifixo
E - Alado
c - c/ panejamento
$V$ - Livro
$F$ - Trespassado por foice
d.c/ chama
e - asa de corvia
VI - Globo 


\begin{tabular}{|c|c|c|}
\hline $\begin{array}{l}\text { VII - Panejamento } \\
\text { VIII - Pergaminho } \\
\text { IX - Trombeta } \\
X \text { - Cálice } \\
X I \text { - Âncora } \\
\text { XII - Foice } \\
\text { XIII - Bastão } \\
\text { XIV - Elmo } \\
\text { XV - Coração } \\
\text { XVI - Porta-retrato } \\
\text { XVII - Cesto }\end{array}$ & $\begin{array}{l}\text { G - Simples } \\
H \text { - Decorada } \\
\text { I - c/ inscrição } \\
J \text { - Imitando galhos } \\
K \text { - de Malta } \\
L \text { - Lobada } \\
M \text { - Cruzadas } \\
N \text { - Em figura de anjo } \\
O \text { - Em figura feminina }\end{array}$ & $\begin{array}{l}\text { g- asa de outros } \\
\text { - monte de pedras } \\
\text { - - estilizada } \\
\text { - c/ serpente } \\
\text { k-cruzadas entre si } \\
\text { l-c/ anjos } \\
\text { m-c/ pombos } \\
\text { - c/pergaminho/livro } \\
\text { o- inciso na lápide }\end{array}$ \\
\hline
\end{tabular}

As representações iconográficas levantadas no campo, enquanto categorias tipológicas, devidamente codificadas através das siglas alfa-numéricas, foram introduzidas em planilhas eletrônicas, quantificadas, processadas estatisticamente e analisadas à luz de um raciocínio seriacional, na medida em que este procedimento permitiu verificar o seu comportamento diacrônico.

Nas planilhas foi possivel constatar que o expressivo número de jazigos sem referências cronológicas seria capaz de alterar o perfil iconográfico do cemitério, no caso de serem simplesmente ignorados. A estratégia desenvolvida para contornar esta dificuldade consistiv, em primeiro lugar, na observação das datas apostas não apenas às sepulturas mais próximas, mas também ao longo da aléia em que estão situados. Na grande maioria dos casos, o conjunto dessas datas está dentro de um intervalo cronológico pequeno, em função da ocupação progressiva das aléias, o que torna esses jazigos relativamente contemporâneos.

A etapa seguinte consistiu no cálculo de uma data média para cada sepultura sem referência cronológica, a partir das sepulturas vizinhas, utilizando-se o conjunto de datas da aléia para a confirmação da estimativa. Considerou-se mais seguro sustentar as estimativas nos limites de uma década, ou seja, bem amplos, julgando-se temerário trabalhar com intervalos menores. Como resultado, os gráficos de freqüência dos signos apresentam as ocorrências por décadas e não por ano, como seria mais desejável.

As freqüências obtidas foram devidamente interpretadas, analisando-se a sua relação com mudança social e cultural e entendendo-se - aumento e a diminuição da popularidade de cada categoria como resultante de uma complexa conjunção de fatores ideológicos, políticos, econômicos e sociais.

Resultados obtidos

Foi levantado e analisado um total de 2.520 sepulturas, situadas cronologicamente entre 1850 e a entrada do século XX (1903), sendo 679 do Cemitério do Catumbi e 1.841 do Cemitério São João Batista. 
O gráfico $n^{\circ} 1$ apresenta a distribuição da freqüência dos jazigos por décadas, em cada um desses cemitérios, ao longo do século XIX. O Catumbi, um cemitério particular de ordem religiosa, teve evidentemente uma ocupação mais restrita, menos densa, porém uniforme. Esta uniformidade se manteve até os anos 70 e parece corresponder a um número relativamente constante de membros adquirindo jazigos perpétuos. Nas décadas de 80 e 90, no entanto, com o incremento da população urbana no Rio de Janeiro, para o qual contribuiram consideravelmente o colapso da cafeicultura na região do Vale do Paraíba fluminense e a melhoria das condições de saneamento na cidade (Lobo, 1978:469-70), devem ter sido ampliados os quadros da ordem. $O$ número de sepulturas aumentou ligeiramente, porém manteve a regularidade. A mesma tendência foi constatada nos três primeiros anos do século XX.

O São João Batista, enquanto cemitério público, secular, administrado pela Santa Casa, apresentou maior expressão numérica por se tratar de espaço funerário aberto indistintamente a todos, que acompanhou, de modo natural, a expansão demográfica da cidade. A pouca aceitação durante o império fica evidente diante do pequeno número de jazigos perpétuos com ornamentos nas décadas iniciais. Sua ocupação aumentou progressivamente à medida que a monarquia foi se desgastando, até atingir um crescimento exponencial nas décadas finais e nos primeiros anos do século $X X$, quando ele finalmente se estabeleceu como o cemitério das classes dominantes republicanas.

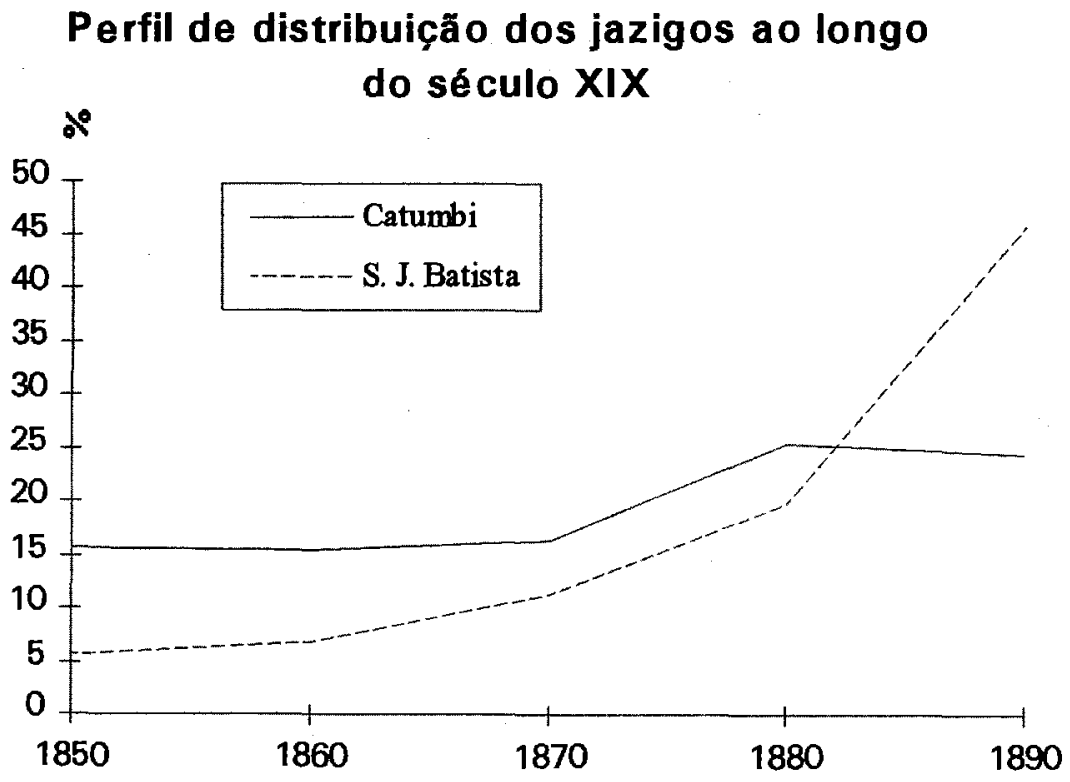


Em ambos os cemitérios, mausoléus e ossários são as categorias de jazigos mais elaboradas artisticamente e nelas foi aposta a maior diversidade de signos, o que é compatível com a sua natureza. Os túmulos, de modo geral, apresentam decoração mais discreta, embora aí também tenham sido executadas muitas composições pomposas, monumentais.

Através do tratamento quantitativo dos dados nas planilhas eletrônicas foi possivel constatar os tipos de maior ocorrência nas duas amostras. Os signos que apresentam a freqüência mais expressiva nos dois cemitérios são os objetos, já que aí estão incluídas cruzes e urnas. As primeiras constituem indiscutivelmente o signo de maior popularidade: o Catumbi apresenta 417 túmulos com cruzes, no período analisado, e o São João Batista, 1206. Se quantificadas isoladamente, esse número aumenta, já que um mesmo túmulo pode apresentar mais que uma cruz.

Estão presentes desde a inauguração dos dois espaços funerários, representadas sob as mais diversas formas: simples, lobadas, de Malta, formadas por galhos cruzados, fincadas em montículos de pedras, acompanhadas por pequenos livros ou pergaminhos. Podem apresentar folhagens em trepadeiras, decoração floral, formando coroas ou ramalhetes, mais raramente inscrições, ou não ter qualquer tipo de decoração. Ocorrem em grande número apenas incisas na lápide. Somente no início do século XX aparecem sob a forma de crucifixo, ou seja, com a imagem aposta do Cristo crucificado. São muito mais freqüentes nos túmulos, aparecendo menos nos mausoléus e ossários.

As urnas ocupam o segundo lugar em popularidade. Colocadas em geral nos ossários, contêm sepultamentos secundários, desarticulados, e com freqüência estão associadas a signos ligados ao fogo. Foram quantificados 235 jazigos com urnas no Catumbi e 106 no São João Batista. Em forma de vasos, em geral com tampa, possuem outros formatos bastante diversificados: piramidais, quadrangulares, etc. Em grande parte dos casos estão encimadas por chamas ou parcialmente encobertas por panejamentos que caem displicentemente sobre elas.

Os objetos mais expressivos que se seguem a ambos são tochas, seguidas por ampulhetas, âncoras, foices e globos. Mais tardiamente, no início do século, surgem corações e porta-retratos. Esses objetos são de baixa dominância visual no espaço funerário e em geral compõem campos decorativos secundários. Podem aparecer combinados a signos fitomorfos (coroas e ramalhetes de flores e folhas, cornucópia de frutos), zoomorfos lampulhetas com asas de morcegos, corujas, etc.; urnas com suportes em patas de leão; bastões e foices com serpentesl, enlaçados por fitas, parcialmente encobertos por panejamentos, entre outros.

Em segundo lugar aparecem os signos antropomorfos, em geral de grande dominância visual nas sepulturas. O São João Batista possui 485 jazigos com representações humanas, no intervalo cronológico analisado, e o Catumbi, 211. Os que aparecem sob forma de anjos, ou seja, portando asas, são os mais freqüentes, seguindo-se as representações femininas. Crianças ocupam a terceira posição, enquanto as masculinas têm pouca expressão numérica, limitando-se a umas poucas unidades. 
Os zoomorfos têm nas serpentes que engolem o próprio rabo o signo de maior popularidade desta categoria. Os demais, como morcegos, corujas e patas de leão, aparecem associados a outras formas, quer emprestando suas asas às amputhetas ou servindo de suporte para urnas. Em poucos casos foram colocados isoladamente, com dominância visual.

A análise do comportamento desses signos através do tempo permitiu reconhecer três padrões dominantes na representação da morte, que podem ser assim sistematizados:

- Padrão Inaugural, que domina os espaços funerários entre 1850 e 1888.

- Padrão de Transição, que se instala por um curto período, entre 1889 e 1902.

- Padrão de Consolidação, implantado entre 1903 e 1930.

Esses padrōes, reconhecidos através dos procedimentos quantitativos descritos e aplicados apenas aos dois cemitérios acima referidos, foram confirmados através de avaliação visual nos demais. O último, por exceder 0 recorte cronológico proposto, foi apenas caracterizado, não tendo sido trabalhado estatisticamente.

Os signos utilizados e o estilo adotado para essas representações foram analisados no âmbito do cenário econômico, político e ideológico no qual se movia a sociedade que os produziu ou adotou, numa tentativa de entender os mecanismos responsáveis por essas mudanças.

Padrão inaugural: $1850-1888$

Tem início com a efetiva ocupação dos cemitérios no Rio de Janeiro e se estende até a ruptura do modo de produção escravista, com a conseqüente transição para o capitalismo emergente. As classes dominantes da sociedade (aristocracia rural, alta burocracia civil e militar, grandes comerciantes, etc.) investem consideravelmente na morte nesse período. Inúmeros sepultamentos feitos antes em igrejas são transferidos para os novos espaços funerários e colocados em pomposos ossários, nas suas principais aléias (fotos 3 a 7). São erigidos ou diretamente importados da Europa (particularmente de Portugal) inúmeros mausoléus, de caráter monumental, ocupando eixos transversais e confirmando diferenciações de status social (fotos 1 e 2 ). Esse investimento é maior nas décadas iniciais, declinando à medida que se deteriora a monarquia escravista e o principal sustentáculo da sua economia, a empresa cafeicultora fluminense. Também no início desse período é feito um considerável investimento no espaço urbano, com inúmeros projetos para a construção de diversos prédios públicos, instalação de iluminação a gás, implantação de linhas de bondes, etc., numa tentativa de transformar a cidade "barroca", de feição portuguesa, em uma moderna capital.

As sepulturas desse momento, que em grande parte apresentam apuro artesanal e qualidade artística, expressam claramente os valores desses segmentos dominantes. Ao importarem mimeticamente o modo de vida assumido pela burguesia florescente da Europa ocidental, transplantam para os cemitérios do Rio de janeiro os modelos vigentes nos espaços funerários europeus. 
As representações da morte no império escravista são escatológicas, macabras, mórbidas. Signos que remetem à consumação dos tempos, como caveiras com tíbias cruzadas; orubouros, a serpente alquímica que engole o próprio rabo; fachos e tochas acesas, porém voltadas para baixo; ampulhetas aladas, foices, machados, globos alados, além de morcegos, corvjas e plantas narcóticas, entre outros, são os leitmotiv da arte tumular nesta fase (pranchas 1 a 7). As representações da figura humana são chapadas, sem exuberância de formas, sem sensualidade. Os corpos são esbeltos, elegantes, classicamente trajados. As suas expressões denotam emoções contidas, controladas, e as atitudes são de reflexão. Não há desespero, não há tristeza, só melancolia (fotos 3 e 4 ). O branco domina a totalidade do espaço funerário.

Essa sociedade, que transplantava a ideologia do ocidente europeu e importava em doses maciças a maioria dos seus bens de consumo, inclusive túmulos e mausoléus inteiros, adotou em meados do século, nos seus espaços funerários, o modelo do classicismo romântico (cf. Giedion, 1922) em vigor na Europa, entre 1800 e 1840.

movimento neo-classicista, essencialmente burguês, surgiu como uma reação ao artificialismo, à frivolidade, à sensualidade, ao brilhantismo e riqueza cromática do rococó, valorizando a simplicidade, a contenção, a severidade, a objetividade e a brancura dos monumentos clássicos. Diferindo substancialmente do antigo classicismo das monarquias absolutistas do século $\mathrm{XVII}$, que interpretavam o mundo greco-romano através da sua própria ótica e valores morais, este novo classicismo surgiu compromissado com os ideais da burguesia em processo de afirmação e consolidação.

Enquanto movimento, desdobrou-se em duas vertentes, ambas claramente representadas neste primeiro momento identificado nos cemitérios cariocas: o classicismo arqueológico e o neo-medievalismo romântico, que se mesclaram e interpenetraram na arte tumular dos espaços funerários analisados, criando expressões híbridas.

O classicismo arqueológico, ao redescobrir a antiguidade clássica a partir das grandes descobertas arqueológicas do século XVIII (Herculano, 1737; Pompéia, 1748), que despertaram a paixão pelo antiquariato e pela procura de obras clássicas, estimulando uma verdadeira febre de escavações, elegeu como seu grande modelo o mundo grego, romano, etrusco e egípcio. É essa vertente que impõe aos cemitérios o mármore branco, os templos, edículas e colunas greco-romanas, os obeliscos e pirâmides egípcias, as urnas em forma de ânforas, as tochas e fachos.

Pearson (1982), ao disculir o simbolismo da comunicação ritual, que não se refere necessariamente às verdadeiras relações de poder, mas a uma expressão idealizada dessas relações, assinala que as reinterprelações em miniatura dos gigantescos monumentos do passado da humanidade podem ser entendidas como associações com o esplendor dessas civilizações, para assim obter uma legitimação implícita da ordem social corrente, em termos daqueles valores.

Já o neo-medievalismo romântico, ao se rebelar contra os exageros do classicismo arqueológico, propôs uma revivescência do estilo gótico, entendendo-o como uma representação autóctone das culturas nórdicas. A 
exaltação nostálgica da Idade Média, expressada nesse neo-gótico, manifestou-se dominantemente na arquitetura religiosa (igrejas) e funerária (cemitérios). Esta vertente não apenas introduziu seus próprios motivos na arte tumular (morcegos, corujas), mas também incorporou elementos dos movimentos anteriores ao surgimento da burguesia (caveiras, foices, ampulhetas, serpentes), só que transformando-os à sua feição.

Traduzidos e retrabalhados, esses signos foram reintegrados ao imaginário classicista romântico da morte, em sua própria perspectiva. Ao contrário do barroco, que tanto enfatizou o contraste entre a vida e a morte, expondo a decomposição da carne, a ação dos vermes, a podridão, a degenerescência, o neo-medievalismo romântico fugiu, com medo, desse confronto, representando a morte apenas fantasmagoricamente, à distância. Essa vertente nunca aparece em sua forma pura nos cemitérios do Rio de Janeiro, mas sempre mesclada a elementos do classicismo arqueológico. Suas principais manifestações estão nos mausoléus, dos quais muitos reproduzem capelas góticas miniaturizadas, inclusive com criptas.

Neste primeiro momento ocorrem ainda, paralelamente, em pequena escala, algumas expressōes neo-renascentistas e neo-barrocas, também como resultantes desse movimento de valorização dos estilos antigos, que configura o historicismo na Europa, por volta de 1840.

Nessa nostalgia pelo passado, a classe burguesa fugiu à sua própria realidade, abrigando-se na fantasia e no sonho. Valorizando o inconsciente, a introspecção, os conflitos internos, a loucura, o fantástico e exaltando o poder criador da imaginação, produziu seus signos com base no sentimento e na emotividade. Conforme assinala Hauser (1972:834), "o romântico mergulhou impetuosamente no seu duplo, em tudo o que é obscuro e ambíguo, caótico e beatífico, demoníaco e dionisíaco, e buscou nisso um refúgio contra a realidade que era incapaz de dominar por meios racionais".

Elementos noturnos (as corujas, os morcegos), espectrais, fantasmagóricos (a cor branca), sinistros (caveiras, ossadas, foices), terríficos (serpentes), soníferos (papoulas), inexoráveis (ampulheta alada) compõem o repertório romântico neste primeiro momento dos cemitérios cariocas, "num verdadeiro culto do misterioso e do tenebroso, do fantástico e do grotesco, do horrível e do fantasmagórico, do diabólico e do macabro, do patológico e do perverso" (Hauser, op. cit.:835).

imaginário do classicismo romântico reafirma assim, através dos signos produzidos, o antigo mito da Morte/Sono, referido por Urbain (1978). Thanatos e Hypnos são ambos filhos da Noite, reino das trevas, que é povoado, entre outros, por morcegos, corujas, serpentes, signos metonímicos. Nos domínios subterrâneos, obscuros e tenebrosos, os mortos dormem o Grande Sono, o Sono Eterno, metaforizado pelas papoulas. Os túmulos são concebidos como leitos, onde os corpos são dispostos distendidos, no interior da terra, com olhos fechados, em atitude de repouso, como quem dorme ("Aqui jaz ..." "Aqui repousa..."). O cemitério (do gr. koimêtêrion = lugar onde se dorme; koimáo = dormirl é um espaço disciplinado, silencioso, onde se fala baixo, de modo a que não se perturbe o sono dos mortos.

Assimilando esses modelos com pelo menos vinte anos de atraso em relação à Europa, os cemitérios do Rio de Janeiro foram impregnados por essa 
estética do classicismo romântico, entre 1850 e 1888 . Esta defasagem fica claramente perceptível diante da adoção de padrões que na Europa, ao tempo em que aqui foram implantados, já eram considerados demodés, provincianos.

Em um período de expansão econômica, não obstante eventuais pulsações recessivas determinadas por conjunturas de mercado, as classes dominantes, com capital em disponibilidade, investiram maciçamente na morte e, através dela, em sua própria imagem. Seus epitáfios expressam os seus anseios de diferenciação e prestígio, suas atitudes de exibição e auto-promoção, e a magnificência de seus túmulos dá a medida das suas aspirações à ascensão social.

Mais pronunciada nas décadas iniciais, essa feição vai se atenuando paulatinamente, à medida que declina o sistema escravista, cedendo espaço para o signo da cruz, que invade os cemitérios com força crescente.

O gráfico 2 mostra a dominância dos signos escatológicos no Catumbi - o cemitério das elites imperiais - entre 1850 e 1860, presentes em cerca de $65 \%$ dos jazigos. Já no São João Batista, cemitério público onde se enterravam todas as camadas da sociedade e que não desfrutou da mesma preferência, os signos escatológicos estão presentes em cerca de $20 \%$ das sepulturas da década, conforme demonstra o gráfico 3, um percentual que possivelmente corresponde aos segmentos com poder aquisitivo suficiente para adquiri-los, posto que estão situados nas aléias mais nobres e de maior visibilidade no cemitério. A tendência, em ambos os espaços funerários, é de declínio acentuado desses signos em direção ao final do século.

Padrão de transição: 1889 - 1902

"1888 (...). 10 de janeiro. Fomos ao cemitério (São João Batista) (...). Não é feio o nosso jazigo; podia ser um pouco mais simples - a inscrição e uma cruz - mas o que está é bem teito".

Conselheiro Ayres, em Memorial de Ayres (Machado de Assis, 1944b: 13).

Período que corresponde à emergência da ordem capitalista republicana, compreendido entre a queda do império e o final do governo Campos Salles, em 1902. Bastante tumultuado, marcado por fortes crises políticas, econômicas, financeiras e sociais, foi decisivo para a constituição e consolidação do novo regime (Cardoso, 1975:37).

Caracteriza-se por uma progressiva ascensão da burguesia e, paradoxalmente, por um notável empobrecimento da arquitetura tumular. As construções monumentais, os mausoléus, diminuem consideravelmente nesse período. As representações escatológicas da morte, paulatinamente substituídas pelo signo da cruz, em múltiplas variações, praticamente desaparecem. A popularidade das cruzes aumenta de modo notável. Com o advento da república, uma dessas variações assume a dominância sobre as demais, constituindo um novo leitmotiv e disseminando-se com força crescente nos túmulos dessa época: uma cruz singela, em geral imitando galhos, fincada em 
um montículo de pedras (prancha 8), ao pé do qual muitas vezes é colocado um pequeno livro aberto ou um pergaminho parcialmente desenrolado (fotos 11 e 12).

Os gráficos 4 e 5 mostram o crescimento progressivo do leitmotiv da cruz sobre pedras ao longo da segunda metade do século XIX. Pouco expressivo entre 1850 e 1870 , espraia-se por cerca de $25 \%$ dos jazigos em ambos os cemitérios, entre 1870 e 1890, para finalmente predominar em cerca de $60 \%$ das sepulturas do São João Batista, o cemitério dos republicanos, na última década do século. No Catumbi, não obstante tratar-se de cemitério religioso, ocupou cerca de $30 \%$ dos jazigos nesse mesmo intervalo de tempo. Os três primeiros anos do século XX registram uma tendência de alta desse signo nos dois espaços funerários.

Os gráficos 6 e 7 mostram, em contraposição, a retração dos signos escatológicos e a expansão da cruz sobre pedras ao longo da segunda metade do século, caracterizando o processo de substituição de uma categoria de signos pela outra.

Os gráficos 8 e 9 apresentam as freqüências comparadas do signo da cruz, com suas múltiplas variaçōes agrupadas, detalhando apenas a cruz sobre pedras, e dos signos escatológicos.

Todas essas cruzes, que não carregam em si o sentido religioso do suplício de Cristo, cuja imagem jamais the é aposta nesse momento, parecem meramente retomar uma antiga conotação, com raizes na Idade Média ou talvez muito antes: a de simples marcos de referência, sinalizando apenas a presença de um morto. A variante destacada corresponde ao modelo de túmulo mais simples e pobre, que evoca dois galhos de árvore cruzados e fincados sobre um montículo de terra (ou pedra, no caso), à beira de qualquer caminho, marcando a presença da sepultura anônima de uma pessoa modesta, desconhecida (foto 9). Representação geometrizada e metafórica do corpo humano, desvinculada do sentido que the atribui o catolicismo, não obstante impregnada de religiosidade, a cruz parece ser utilizada simplesmente como o signo da morte.

A produção funerária deste período é massificada, de modo geral sem qualidade artística, com poucas exceções, e os antigos signos, quando aparecem, repetem velhas fórmulas já desgastadas, com expressões surradas, sugerindo o trabalho de artesãos marmoristas pouco criativos, que não foram capazes ou não tiveram motivação suficiente para renovar seu repertório.

Um signo antropomorfo, por exemplo, apresenta uma notável persistência temporal: trata-se de um anjo/criança ajoelhado sobre uma almofada em atitude de oração, designado nos álbuns dos marmoristas à época como "anjo espreme-limão", em virtude da posição das suas mãos (fotos 17, 181. Presente desde a inauguração dos cemitérios, sustenta uma relativa estabilidade por várias décadas, em cerca de $5 \%$ a $10 \%$ dos túmulos levantados, mantém-se com ligeira retração na década final e adentra consideravelmente o século XX. Os gráficos 10 e 11 , que expõem a regularidade da distribuição dos signos antropomorfos em geral por todo o período analisado, detalham a sua freqüência. Há casos de sepulturas que chegam a apresentar três ou até mesmo quatro desses anjos apostos a uma 
mesma lápide (fotos 19 e 20). De início sem asas, à medida que o signo vai se vulgarizando, os marmoristas acrescentam-nas, como novidade máxima em oferta. Este anjo perdura por cerca de 70 a 80 anos nos espaços funerários da cidade, atestando a desmotivação e o desinteresse dos ateliês pela criação de novos modelos.

Os que compram esse tipo de produto, nesse momento, aparentemente se satisfazem com ele, o que revela um surpreendente desinteresse no tratamento dispensado aos mortos. As sepulturas são banais, convencionais, em sua esmagadora maioria, e o igualitarismo decorrente dessa massificação quase nivela os mortos entre si (foto 10). Aristocratas, militares de qualquer patente, pequenos burgueses, recebem indistintamente em seus túmulos signos semelhantes, sem a pompa e a magnificência do período anterior, acrescidos apenas de um ou outro símbolo (brasão, coroa, comenda, armas ou menção, no epitáfio, de sua condição profissional e social) que promove a diferenciação entre eles. Em casos extremos, apenas o nome, o título nobiliárquico e as datas de nascimento e morte são impressas nas lápides, sem qualquer ornamento (fotos 13 a 16). O branco se mantém como a cor absoluta do espaço funerário. A sociedade pouco investe na morte nesse período.

Na citação acima, Machado de Assis expressa, através do comentário feito pelo Conselheiro Ayres, em 1888, sobre o seu jazigo de família, a estética funerária que se anuncia entre os estamentos mais elevados da sociedade: a opção pela simplicidade, pelo signo da cruz, acrescido apenas da inscrição, em oposição ao que existia antes.

O leitmotiv da arquitetura tumular desse momento de transição parece conter, em um mesmo e único signo, alguns dos princípios fundamentais pregados pelo movimento positivista, em plena efervescência nesse período. $O$ fraternalismo, a crença na unidade fundamental da espécie humana, a solidariedade social e a irmanação das classes /a cruz que iguala indistintamente os mortos), a admiração e o fervor pela natureza expressos na concepção do "bosque sagrado", imprescindivel ao culło positivista (os galhos), - cientismo, o gosto pela leitura e pelo estudo, o progresso através da educação (o livro aberto, o pergaminho/diploma) sugerem a impregnação, também do espaço funerário, pelo estado de espírito positivista que tomou conta da sociedade ao final do século.

A doutrina, que valorizava particularmente o estilo alegórico de monumentos, sobretudo os escultóricos, tinha especial apreço por túmulos e cemitérios, entendendo que esses espaços "prolongavam a ação moralizadora da família, para além da existência objetiva dos seres que dela fazem parte" (Ariès, 1982:590).

O pensamento comtiano pretendeu, em sua etapa inicial, varrer o subjetivismo, a fantasia e o sobrenatural romântico, colocando em seu lugar a precisão, a verdade, a objetividade, tendo a natureza la realidade, o mundo exterior) como o grande modelo. $O$ desenvolvimento científico e os avanços tecnológicos exigiam um novo compromisso, agora com o concreto, o exato, o real.

Posteriormente desvirtuado e transformado em Religião da Humanidade, mesmo assim impregnou fortemente a sociedade com esses 
princípios, adentrando os primeiros anos do século XX. Conforme ressaltou Bosi (1992:280), ao discorrer sobre a perduração do positivismo, "esquemas mentais não cessam abruptamente de funcionar, resistindo enquanto servirem como veículos úteis para racionalizar interesses e vontades". Definidos por Carvalho (op. cit.) como os mais articulados manipuladores de símbolos do novo regime, os positivistas parecem ter contribuido substancialmente para a transformação da representação da morte ao final do século XIX. Não se trata, aqui, da difusão da doutrina em si, que apenas as elites letradas foram capazes de absorver, mas da infiltração sutil dos seus ideais, disseminados através de uma eficiente propaganda subliminar, por meio de imagens, símbolos, alegorias, ritos e mitos, que conseguiu atingir a praticamente todos os segmentos da população, até mesmo os mais baixos, não letrados.

Esse esvaziamento do culto romântico da morte sugere claramente ser fruto da penetração desses novos valores racionais. Entretanto, o aparente desinteresse pelo espaço funerário nesse curto intervalo de tempo, longe de ser produto de novos esquemas mentais, parece resultante do pesado clima antimonarquista dos primeiros anos da república, provocado pelo movimento jacobino, e do dramático episódio do Encilhamento. Estes parecem ter sido os principais fatores que contribuíram para dar aos cemitérios cariocas a surpreendente feição que eles assumem nesse momento de transição: empobrecida, banal, nivelada.

Por ser o tratamento dispensado à morte um dos domínios onde as sociedades se mostram mais conservadoras e um dos que mais persistem na longa duração, este fenômeno de desapreço pelas sepulturas, em um intervalo de tempo tão restrito, é surpreendente. Pela sua transitoriedade, sugere ter sido mais propriamente resultante de pressões externas, conseqüência desta conjunção de fatores no conturbado processo de consolidação da república em seus primeiros anos, que a expressão de uma nova mentalidade.

O temor de uma possível restauração monárquica, onipresente a partir da implantação do regime republicano em 1889, exacerbou-se no governo Floriano Peixoto, instalado em novembro de 1891, com a renúncia de Deodoro. A impressionante resistência do presidente à Revolta da Armada, em 1893, fez surgir o jacobinismo, um violento movimento de defesa dos ideais republicanos, fortemente nacionalista e radical, que emergiu de forma relativamente espontânea entre as camadas médias urbanas, com a conivência do governo e sob a proteção da espada do Marechal de Ferro.

De caráter militar positivista, patriótico, intolerante, defendendo um estado forte, autoritário, ditatorial, sob a forma de uma república federativa e presidencialista, com a soberania nacional acima de tudo, este movimento, estudado em maior profundidade por Queiroz (1986), foi responsável por um periodo de intensas agitações. Em meio a um clima de permanente sedição, os jacobinos espalharam terror através de ações armadas contra possíveis monarquistas, proclamando-se "as sentinelas vigilantes da República".

Social, cultural e ideologicamente heterogêneos, esses segmentos médios urbanos incluíam desde militares de baixa e média patentes, pequenos proprietários, professores, funcionários de repartições públicas, estudantes, guarda-livros, pequenos comerciantes, artesãos, ferroviários e telegrafistas, até 
profissionais liberais, como advogados, médicos, engenheiros e farmacêuticos, assim como jornalistas e parlamentares; bem distantes, portanto, não só do operariado mas também dos grupos dominantes (Queiroz, 1989).

Esses segmentos, até então passivos, que se limitaram a assistir "bestificados" ao golpe de 15 de novembro, na famosa expressão de Aristides Lobo, transformaram-se em grupos politicamente ativos, unindo-se em defesa de melhores oportunidades para os seus setores, francamente desfavorecidos pelo regime monárquico e conferindo ao movimento intensa participação popular (Carvatho, 1987).

Perseguindo implacavelmente os portugueses (que controlavam o comércio, seus empregos, e os prédios de aluguell, a quem atribuíam simpatias monarquistas, e entendendo que os fins justificavam a violência dos meios, promoviam toda sorte de agressões físicas e verbais, quer em desordens de rua, quer através da imprensa.

Os estratos mais baixos corriam atrás dos portugueses, que constituíam cerca de $20 \%$ da população, aos gritos de "mata galegos!"; promoviam linchamentos e assassinatos, assaltavam suas lojas, incendiavam seus armazéns, empastelavam jornais, enquanto os mais intelectualizados escreviam artigos em linguagem virulenta, incitando à desordem, em periódicos como "O Jacobino" e "A Bomba", mais tarde transformado em "O Nacional". Discursos exacerbados eram proferidos no Parlamento, nos clubes jacobinos, em comícios e nos meetings, com intensa participação das "comissões de agitação pública", que invariavelmente terminavam em pancadarias (Queiroz, 1986:81). Entusiasmados pelas atitudes duras e pela pronta e enérgia reação do chefe do governo aos desafios e ameaças ao regime, deram-the considerável sustentação popular.

A ditadura florianista, por seu lado, decretando e prolongando o estado de sítio, rompendo relações com Portugal, recrutando tropas, criando milícias armadas, os chamados "batalhões patrióticos", coibindo a crítica, encarcerando os opositores ao regime, "execulando ou deixando executar seus inimigos, sem que ficasse vestígio, como se o Brasil, no século dezenove, tivesse retrogradado ao estado de Roma no reinado dos Bórgias" (Nabuco, 1949b: 271), semeou um clima generalizado de terror, particularmente intenso no Rio de Janeiro.

Ainda segundo Joaquim Nabuco (1949a: 252), "o regime da Casa de Correção imposto a homens de caráter ilibado, ao que a sociedade do Rio de Janeiro possuía de melhor, o modo porque se davam as buscas, o silêncio que se impunha a respeito das prisões, a incerteza do destino que aguardava os presos, a sua incomunicabilidade durante a encarceração, o susto em que viviam até mesmo de serem sufocados à noite pela cal (...), esse conjunto de medidas, próprias para inspirar terror e manter a cidade imóvel, constituía uma verdadeira e flagrante tirania".

A sucessão de Floriano por Prudente de Moraes, em 1895, contrária aos interesses dos adeptos da ditadura, aumentou a tensão social, partindo os jacobinos para confrontos abertos com o governo civil, acusado de fraco e tolerante para com os monarquistas. Prudente de Moraes, ao desmilitarizar o país, reatar relações com Portugal, anistiar os rebeldes federalistas e os revoltosos 
da Armada, potencializou a ira dos fanáticos, que entenderam essas medidas como tentativas de restauração da monarquia, e, em 1897, ao promoverem um atentado contra a sua vida, acabaram vitimando seu ministro da guerra.

O impaclo fortemente negativo deste episódio sobre a opinião pública apagou o furor jacobinista e extinguiu de pronto o movimento, ao qual Queiroz (op. cit.) atribui uma delimitação cronológica bastante precisa: entre 1893 e 1897, ou seja, entre a Revolta da Armada e o atentado. Não obstante classificado por Nabuco (op. cit.: 263) como "uma moda de época, um pastiche histórico", o jacobinismo manteve-se por mais algum tempo, persistindo ainda consideravelmente no imaginário popular, conforme detectado por Cardoso (1989).

Totalmente equivocados ao avaliar a Revolta da Armada como um movimento de adesão à monarquia, na verdade resultante da rivalidade entre exército e marinha (Hahner, 1975:61), e ao atribuir a portugueses e monarquistas os entraves aos seus interesses, os jacobinos não foram capazes de perceber, em sua ótica limitada, que eram os cafeicultores paulistas, já dominantes no cenário político e econômico, os seus verdadeiro antagonistas. (Queiroz, 1989:237).

Este clima de suspeição, de insegurança generalizada, de restrições severas às liberdades individuais civís atemorizava a população, que, apavorada, temia ser confundida com monarquistas. Impunha-se a prudência, a discrição, a sobriedade, o recolhimento. A eliminação de sinais aparentes de identificação com os adeptos do antigo regime era uma questão de sobrevivência, que parece ter se estendido também aos espaços funerários.

Esta foi, sem dúvida, uma das razões pelas quais o cemitério da monarquia por excelência, o velho Catumbi, entrou em declínio, saiu de moda, repudiado pelas novas elites da república que elegeram o São João Batista como seu espaço funerário, a par do deslocamento do eixo elegante da zona norte (Catumbi e arredores: Rio Comprido, Mata Porcos, Andaraí, São Cristóvão) para a zona sul (Botafogo e adjacências: Flamengo, Catete, Laranjeiras, Cosme Velhol, em busca de locais mais frescos, arejados e aprazíveis.

Por outro lado, a total separação entre Igreja e Estado promovida pelo regime republicano, e inscrita na Constituição de 1891, foi outro fator que contribuiu consideravelmente para esta transferência. Fortemente positivista, a primeira Constituição da república promoveu a laicificação do Estado em vários de seus artigos, determinando, entre outras medidas, a secularização dos cemitérios. Ao submeter a administração dos espaços funerários, inclusive os religiosos, às autoridades municipais, retirou da lgreja o controle sobre a empresa funerária, enfraquecendo bastante a sua participação nesse processo.

Por sua vez, o dramático episódio do Encilhamento, movimento de desenfreada especulação bolsista, decorrente da política financeira implantada pelos governos militares, caracterizado pela expansão desmedida de créditos e pela emissão em larga escala de papel moeda, fez triplicar o meio circulante, determinando uma forte depreciação cambial. Estas medidas, altamente inflacionárias, provocaram uma falsa euforia industrial, estimulando a 
negociação de papéis e ações das novas empresas abertas com o surto. Grandes fortunas apareceram do dia para a noite. Havia dinheiro, muito dinheiro, mas não para ser investido na morte, que não multiplicava o capital real, mas sim na bolsa, que fazia milionários aos borbotões.

É o mesmo Machado de Assis que, em Esaú e Jacob (1944a:275), assim descreve o episódio: "Quem não viu aquilo não viu nada. Cascatas de idéias, de invenções, de concessões rolavam todos os dias, sonoras e vistosas para se fazerem contos de réis, centenas de contos, milhares, milhares de milhares, milhares de milhares de milhares de contos de réis. Todos os papéis, aliás ações, saiam frescos e eternos do prelo. Eram estradas de ferro, bancos, fábricas, minas, estaleiros, navegação, edificação, exportação, importação, ensaques, empréstimos, todas as uniões, todas as regiões, tudo o que esses nomes comportam e mais o que esqueceram. (...) Nasciam as ações a preço alto, mais numerosas que as antigas crias da escravidão, e com dividendos infinitos. Pessoas do tempo, querendo exagerar a riqueza, dizem que o dinheiro brotava do chão, mas não é verdade. Quando muito, caía do céu".

Esta política de desvalorização da moeda, entretanto, realimentava a inflação e pôs em dificuldades as empresas que, sem condições de fazer frente a seus compromissos, foram sendo progressivamente levadas à falência. As grandes fortunas, surgidas meteoricamente, desapareceram com a mesma velocidade. "Patrimônios seculares" foram destruídos em pouco tempo. A depressão econômica que se seguiu ao Encilhamento teve como conseqüência direta um fenômeno de empobrecimento coletivo que atingiu indistintamente a todos os segmentos da sociedade. O dinheiro desapareceu de circulação e o poder aquisitivo diminuiu consideravelmente, trazendo uma indisponibilidade financeira generalizada ao final e na virada do século.

Com isso, a sociedade perdeu suas referências, suas identidades até então bem marcadas, os mais ricos empobrecendo e os não tão ricos enriquecendo subitamente, o dinheiro mudando rapidamente de mãos, as camadas médias reivindicando agressivamente novas posições, em meio a um clima de "democratização" compulsória, imposto politicamente através da coerção, da censura, da pressão. Os papéis sociais confundiram-se, "igualando" momentaneamente segmentos antes bem diferenciados. Ao "perder a cara" no espaço urbano, essa sociedade "igualou-se" da mesma forma no espaço funerário, sem saber mais quem era quem.

O leitmotiv da cruz, em especial a fincada em um monte de pedras, que aparentemente nivelava os mortos entre si, em nome de uma suposta igualdade da espécie humana, na verdade encobria o seu contrário. É a imagem invertida de uma sociedade onde as desigualdades se acentuavam cada vez mais, sobretudo com o fortalecimento e as possibilidades de ascensão dos novos segmentos médios, que emergiam com o rompimento do império escravista e a intensificação das práticas capitalistas.

Esse notável fenômeno de dissimulação que tomou conta dos cemitérios do Rio de Janeiro na virada do século pode ser mais claramente entendido à luz do que colocam Shanks \& Tilley (1987: 142), para quem um estilo de representação é antes de tudo uma produção social, de natureza eminentemente ideológica, na medida em que é uma expressão de idéias, 
crenças e valores, sendo ativamente manipulado para inverter, encobrir, dissimular e deturpar práticas sociais. Não pode por isso ser tomado, segundo eles, como um simples espelhamento de estratégias e práticas sociais, mas sim como um mediador, que serve para reorientar essas estratégias.

Assim sendo, por um curto período de tempo, a sociedade carioca viveu singularmente, tanto no espaço funerário quanto no espaço urbano, onde tampouco foi feito qualquer investimento significativo, um momento de indefinição. Ao cabo desse intervalo, a burguesia em ascensão reordenou-se, gestando o que viria a ser a sua reentrada triunfal na primeira década do século $X X$, a partir de 1903, marcada pelo que designamos como "padrão de consolidação".

Padrão de consolidação: 1903 - 1930

Período que se inicia com uma reativação econômica e retomada do crescimento, saindo o país da conjuntura recessiva em que se encontrava na transição do século. Com as finanças e o crédito externo parcialmente recuperados pelo governo Campos Salles, Rodrigues Alves assume em 1903, inaugurando uma etapa de grandes investimentos, tanto no espaço urbano quanto no funerário. À semelhança daquele, este passa nesse momento por uma notável transformação, aí instalando-se uma nova linguagem plástica. A burguesia, agora com disponibilidade de capital, volta a investir maciçamente na morte. Com um formidável aparato, erige mausoléus monumentais, introduzindo novos materiais na arquitetura tumular, entre eles metais nobres, como o bronze (foto 32).

A morte agora é um grande espetáculo e o cemitério passa a ser um lugar privilegiado para demonstrações de força e poder sem precedentes. Os segmentos dominantes exibem-se despudoradamente, expondo todo o seu prestígio e imprimindo com vigor a sua marca. Opulência, ostentação, luxo, grandiloqüência são as palavras de ordem nesse momento. Triunfo, a palavra-chave. Artistas renomados são contratados para a produção de obras então consideradas notáveis, importando da Europa concepções novas de arte tumular. Alguns, como Rodolfo Bernardelli, introduzem elementos de vanguarda na escultura funerária. Mausoléus e túmulos continuam a ser importados, sobretudo da ltália e da França.

As camadas médias, entretanto, sem grandes alternativas em função do seu poder de compra limitado, continuam comprando velhos modelos que os marmoristas repetem mecanicamente à exaustão, como o "anjo espreme-limão". A produção artística passa a ser uma exclusividade apenas dos segmentos abastados, capazes de financiar as assinaturas dos grandes escultores da moda em seus túmulos; aos demais, cabe a reprodução em série, saindo de cena os velhos mestres artesãos, artistas anônimos que conferiram aos cemitérios, em sua etapa inicial, a qualidade artística que apresentam.

O erotismo, até então mantido fora dos seus limites, penetra progressivamente no espaço funerário. As estátuas, que em todo o século XIX ostentavam corpos esbeltos, elegantes, quase assexuados e classicamente trajados, explodem agora em sensualidade. As vestes femininas, até então 
pudorosas, tornam-se diáfanas, deixando entrever coxas e nádegas curvilineas, carnudas. Os panejamentos, antes contidos, caem agora displicentemente, deixando ombros e seios à mostra. Suas expressões, que antes denotavam reflexão e melancolia, passam a manifestar emoções intensas, como tristeza e desespero, e não raro um estado de êxtase, que tanto pode ser místico quanto sexual, confundindo o espectador (fotos 21 a 24).

Os anjos assumem uma atitude de triunfalismo, evocando a Ressurreição. Gloriosos, apontam vitoriosamente para o alto, estrela à testa, braços e asas erguidas, empunhando trombetas (fotos 29 e 30), em evidente contraponto com os anjos do século anterior, de asas baixas, braços pendidos, atitudes de meditação. É a Belle Époque, em todo o seu esplendor, que traz para o espaço funerário o Art Nouveau, com o seu intenso decorativismo, a representação realista, o retratismo, as formas curvilíneas, iá anteriormente destacados por Valladares (1972), em sua monumental obra sobre os cemitérios brasileiros. O erotismo, a emoção e a movimentação tomam conta dos cemitérios nas primeiras décadas do século.

Ao visitar o cemitério São João Batista, no início de 1888, e olhar à sua volta o espaço funerário construído até então, o Conselheiro Ayres comenta: "A impressão que me dava o total do cemitério é a que me deram sempre outros; tudo ali estava parado. Os gestos das figuras, anjos e outras, eram diversos, mas imóveis" (Machado de Assis, op. cit.: 13). Esta "imobilidade", característica da estrutura social do império escravocrata, desapareceu junto com a antiga ordem. Uma notável mobilidade foi incorporada à estatuária fúnebre, a partir dos primeiros anos do século XX, a mesma mobilidade que a república capitalista conferiu às camadas intermediárias antes sem perspectivas, imprensadas entre os segmentos polares da sociedade escravista.

Imagens religiosas, cristãs, até então ausentes, começam afinal a penetrar no espaço funerário, embora timidamente. (Nossa Senhora, em diferentes manifestações; Jesus Cristo, em diversas representações; São Pedro, São José, Santo Antônio, São Sebastião, Santa Tereza, etc.). As cruzes paulatinamente transformam-se em crucifixos, ao longo do período. Igualmente são introduzidos nesse momento retratos e estátuas que reproduzem realisticamente as feições, em vida, das pessoas falecidas, marcando as suas individualidades. Essas características se mantêm ao longo de toda a Primeira República.

Considerações finais

Ao se iniciar a segunda metade do século XIX, a sociedade do Rio de Janeiro, vivendo o momento de expansão da economia cafeeira sob o regime escravista, estava bipolarmente organizada. Tendo como principais forças sociais uma classe dominante constituída por segmentos de grande poder político e econômico e uma classe subalterna composta pelos negros e mestiços, pressionando camadas intermediárias ainda pouco expressivas, em processo de consolidação, caracterizava-se pela baixa mobilidade dos seus estratos.

Nessa sociedade, em que poder e lucro foram obtidos através da violência e opressão explícitas, num regime de tirania e perversão, a morte foi 
escancarada nos espaços funerários, exibida aberta e frontalmente, sem sutilezas. Essencialmente escatológica, essa sociedade exerceu sem escrúpulos seus aspectos mais sombrios.

Com a substituição desse regime por uma república progressivamente capitalista, bafejada por princípios "democráticos", onde os segmentos livres intermediários foram ganhando pouco a pouco maior força, acelerou-se a mobilidade social. A antiga estrutura do império escravista ganhou nuances, abrindo perspectivas de ascensão para as camadas médias.

Na passagem de um regime a outro, a transição foi vivida de forma bastante tumultuada. A estrutura social até então fortemente verticalizada, bem marcada, foi profundamente abalada pela ruptura da ordem vigente. Não apenas os antigos segmentos dominantes do império foram deslocados do poder, varridos pelas novas forças republicanas e pelos novos compromissos econômicos (industrialização e trabalho livre na lavoura do café), mas também a febre especulativa que tomou conta do Rio de Janeiro, notadamente entre 1889 e 1892, somada ao democratismo compulsório imposto pelos jacobinos durante a ditadura florianista, entre 1893 e 1897, sob inspiração positivista, mudaram a face da sociedade. Os papéis sociais foram estilhaçados, instaurando-se um momento de grande indefinição e perturbação. A perda súbita de poder políico e de dinheiro, que passou a mudar de mãos com uma rapidez vertiginosa, com grandes fortunas aparecendo e desaparecendo em questão de dias ou mesmo de horas, desorganizou momentaneamente um universo até então alinhado com nitidez.

Este fenômeno de perda de identidade e de crescimento de mobilidade social transparece de modo cristalino no espaço funerário carioca. As cruzes fincadas em montículos de pedra, compondo túmulos iguais, nivelados, banais, ordenados, parecem na verdade corresponder a um momento de profunda desordem e desigualdade, em uma sociedade que buscava reordenar sua própria imagem, já que não conseguia mais se reconhecer, em meio a um vórtice de mudanças que a transformaram consideravelmente. Não obstante, conseguiu reunir, a curto prazo, as condições necessárias para a sua reorganização, à entrada do século XX.

Consolidada a república, poder e lucro continuaram a ser obtidos igualmente através da exploração e da opressão, só que agora dissimuladas, sob a capa de um regime que, por princípio, deveria dar oportunidade a todos. A violência social assumiu formas mais veladas, mais sofisticadas le por isso mesmo talvez ainda mais brutais), de modo a não atentar ostensivamente contra a moralidade hipócrita das novas classes emergentes. A morte, nas suas representações, foi se tornando cada vez menos explícita, à medida que se deteriorava o regime e a ideologia que o sustentava, cada vez mais sutil, até ser praticamente abolida, substituída por uma explosão de vida, de movimento, de erotismo, nunca dantes vista, substituindo-se o pudor em relação ao sexo pelo pudor em relação à morte.

Este aparente paradoxo, a dominância de Eros no espaço de Thanatos, a representação da Vida no espaço da Morte, parece na verdade ter sido a expressão da coerência de uma sociedade que não suportou mais o confronto direto com sua face sombria. A exploração, a violência, a opressão, 
a morte, enfim, embora onipresentes, passaram a ser encobertas, disfarçadas e mascaradas pelos seus contrários. Incapaz de assumi-las, como o fez a escatológica sociedade escravista, matizou-se em novos segmentos, numa tentativa de aproximar seus extremos, de atenuar suas diferenças perversas.

Disposta agora a mostrar sua face luminosa, baniu definitivamente dos seus espaços funerários caveiras, morcegos e serpentes, colocando em seu lugar o triunfo e a sensualidade de uma classe vitoriosa, que antes de tudo desejava orgulhar-se de si mesma. Tirou das suas vistas a morte, permanente denúncia da sua própria finitude e da fugacidade das suas conquistas. Varreu para debaixo do tapete a sua escória, escondeu suas vergonhas, escamoteou e dissimulou a exploração e a opressão, de modo a conseguir conviver com elas, sustentando assim sua imagem esplendorosa e seu desejo de perpetuidade.

Agradecimentos

Aos Profs. Drs. Ulpiano Toledo Bezerra de Meneses e José Sebastião Witter, sucessivamente diretores do Museu Paulista da Universidade de São Paulo, pela excelente acolhida a esta pesquisa, parte de um programa de pósdoutorado em História Social desenvolvido na instituição, sob os auspícios do CNPq.

Ao Prof. Dr. Andreas Hauser, historiador de arte em Zürich, Suiça, pelos generosos ensinamentos; por tudo o que pude ver, através dos seus olhos, dos cemitérios europeus, e sobretudo por ter tornado transparente, na arte tumular, o que para mim antes era opaco.

Aos Profs. Drs. Nicolau Sevcenko, Fernando Antonio Novais e José Carlos Sebe Bom Meihy, do Departamento de História da Universidade de São Paulo, pela boa vontade que tiveram em ler o projeto original e pelas oportunas críticas e sugestões que me fizeram. sugestões.

Ao Prof. Roberto Aguinaga, igualmente pelas valiosas críticas e

Aos arqueólogos Marta Pereira Reis da Fonseca (Cemitério São João Batistal, Ana Cristina de Souza, Antonio Henrique Damásio Martins (†), Andrea Fenzl, Yonara de Oliveira Carrilho e Luis Claudio Pereira Symanski (Cemitério do Catumbil, pela inestimável colaboração no levantamento dos dados de campo.

À desenhista Maria Lilia Gomide da Silva, pela disponibilidade, gentileza e desprendimento na confecção das pranchas.

\section{In Memoriam}

Ao meu bisavô, Marechal Frederico Solon Sampaio Ribeiro, um dos líderes do movimento republicano, cuja sepultura no Cemitério da Soledade, em Belém do Pará, inspirou esta pesquisa. E ao arqueólogo Antonio Henrique Damásio Martins, meu aluno e professor, pelas grandes lições de vida e de morte que me deu. 


\section{BIBLIOGRAFIA CITADA}

ANDERSON, Timothy G. Czech-catholic cemeteries in east-central Texas: material culture and ethnicity in seven rural communities. Material culture, v.25, n.3, p.1-18, 1993.

ARIÈS, Philippe História da morte no Ocidente da Idade Média aos nossos dias. Rio de Janeiro: Francisco Alves, 1977.

. O bomem diante da morte. 2.ed. Rio de Janeiro: Francisco Alves, 1989. v.1

O homem diante da morte. 2.ed. Rio de Janeiro: Francisco Alves, 1990. v.2

ASSIS, Machado de. Esaú e Jacob. Rio de Janeiro, W. M. Jackson, $1944 a$.

Memorial de Ayres. Rio de Janeiro: W. M. Jackson, 1944b.

BENDER, Thomas. The "rural" cemetery movement: urban travail and the appeal of nature. In:

ST. GEORGE, Robert B., ed., Material life in America 1600-1860. Boston: Northeastern University Press, 1988. p. 505-19.

BORGES, Maria Elizia. Arte tumular: a produção dos marmoristas de Ribeirão Preto no período da Primeira República. São Paulo, 1991. Tese (Doutoramento) - Escola de Comunicações e Arte, Universidade de São Paulo.

BOSI, Alfredo. Dialética da colonização. 2.ed., São Paulo: Companhia das Letras, 1992.

BROCK, James; SCHWARTZ, Steven J. A little slice of heaven: investigations at Rincon Cemetery, Prado Basin, California. Historical archaeology, n.25, p.78-90, 1991.

BROOKS, Chris, ed. Mortal remains: the history and present state of the victorian and edwardian cemetery. London: Victorian Society, 1989.

BROWN, Ian W. The New England Cemetery as a cultural landscape. In: LUBAR, Steven I.; KINGERY, W. David, eds. History from things: essays on material culture. Washington: Smithsonian Institution, 1992a.

. The Lamson-Carved Gravestone of Watertown, Massachusetts. In: YENTSCH, Anne E.; BEAUDRY, Mary C., eds. The art and mistery of bistorical archaeology: essays in honor of James Deetz. Boca Raton: CRC Press, p.165-91, $1992 \mathrm{~b}$.

CAMPOS, Adalgisa Arantes. Consideraçôes sobre a pompa fúnebre na Capitania das Minas: o século XVII. Revista do Departamento de História da UFMG, n.4, p.3-24, 1987.

Notas sobre os rituais de morte na sociedade escravista. Revista do Departamento de História da UFMG, n.6, p.109-22, 1988.

CARDOSO, Fernando Henrique. Dos governos militares a Prudente-Campos Sales. In: FAUSTO, Boris, dir., O Brasil republicano: estrutura de poder e economia (1889-1930). São Paulo: Difel, 1975. p.15-50. 
CARDOSO, Maria Helena Cabral de Almeida. A herança arcaica do Jacobinismo. In: CONGRESSO NACIONAL DE HISTÓRIA DA PROPAGANDA, PROCLAMAÇÃO E CONSOLIDAÇÃO DA REPÚBLICA. Rio de Janeiro: IHGB, 1989. Anais.

CARVALHO, José Murilo. Os bestializados: o Rio de Janeiro e a república que não foi. São Paulo: Companhia das Letras, 1987.

_. A formação das almas: o imaginário da República no Brasil. São Paulo, Companhia das Letras, 1990.

CLARK, Lynn Gravestones. Reflectors of ethnicity or class? In: SPENCER-WOOD, S. M., ed., Consumer choice in bistorical arcbaeology. New York: Plenum Press, 1987. p. 383-95.

COATES, Colin M. Monuments and memories: the evolution of British Columbian Cemeteries 1850 - 1950. Bulletin d'Histoire de la culture matérielle, n.25, p.11-19, 1987.

COMBS, Diana Williams. Early gravestone ant in Georgia and South Carolina. Athens/London: University of Georgia Press, 1986.

CORRUCINI, Robert $S$. et al. Osteology of a slave burial population from Barbados, West Indies. American joumal of Physical Anthropology, n.59, p.443-59, 1982.

COSTELLO, Julia G.; WALKER, Phillip L. Burials from the Santa Barbara Presidio Chapel. Historical archaeology, v.21, n.1, p.3-17, 1987.

CROWELL, Elizabeth. Philadelphia gravestones: 1740-1820. Northeast Historical archaeology, n.10, p.23-9, 1981.

CURL, James Stevens. The Victorian celebration of death. London: Newton Abbot.

A celebration of death: an introduction to some of the buildings, monuments and settings of funerary architecture in the Western European tradition. London: Constable, 1972.

DEETZ, James. In small things forgotten: the archaeology of early American life. New York: Anchor Books, 1977.

DEETZ, James; DETHLEFSEN, Edwin N. Death's head, cherub, urn and willow. In: SCHUYLER, Robert L., ed., Historical archaeology: a guide to substantive and theoretical contributions. New York: Baywood, 1978. p.83-9.

DETHLEFSEN, Edwin S. The cemetery and culture change: archaeological focus and ethnographic perspective. In: GOULD, Richard; SCHIFFER, Michael B., eds. Modern material culture: the Archaeology of Us. New York: Academic Press, 1981. p.137-159.

DUPRAT, Visconde de. Relatório da Venerável Ordem Terceira dos Mínimos de São Francisco de Paula da cidade do Rio de Janeiro. Seguido da Notícia Histórica da V.O.T. dos Minimos de São Francisco de Paula do Rio de Janeiro. Rio de Janeiro, 1897.

FARRELL, James J. Inventing the American way of death: 1830-1920. Philadelphia: Temple University Press, 1980.

FOUCAULT, Michel. Vigiar e punir. 2.ed. Petrópolis: Vozes, 1983. . Microfisica do poder. 6.ed. Rio de Janeiro: Graal, 1986. 
FRASCARI, Marco. The iconic relationship between cemetery and town. In: STEINER, W., ed. Image and code. University of Michigan, Michigan Studies in the Humanities, n.2, p.147-16, 1981.

GIEDION, Sigfried. Spatbarocker und Romantiscber Klassizismus. München, 1922.

GITTINGS, Clare. Death, burial and the individual in early modern England. London: Routledge, 1988.

GNOLI, G.; VERNANT, J. P., dir. La mort, les morts dans les sociétés anciennes. Cambridge: University Press/Paris: Eds. de la Maison des Sciences de l'Homme, 1982.

GOFFMAN, Erving. Manicômios, prisões e conventos. São Paulo: Perspectiva, 1974. (Coleção Debates).

GORER, G. Death, grief and mourning in contemporary Britain. New York: Doubleday, 1965.

GUEDES, Sandra P. L. de Camargo. Atitudes perante a morte em São Paulo (séculos XVII a $X I X)$. São Paulo, 1986. Dissertação (Mestrado) - Faculdade de Filosofia, Letras e Ciências Humanas, Universidade de São Paulo.

HAHNER, June E. Relações entre civis e militares no Brasil: 1889-1898. São Paulo: Pioneira, 1975.

Jacobinos versus Galegos: urban radicals versus Portuguese immigrants in Rio de Janeiro in the 1880's. Journal of Interamerican studies and world affairs, v.18, n.2, p.125-54, 1976.

HALL, Roger; BOWDEN, Bruce. Beautifying the boneyard: the changing image of the cemetery in 19th. century Ontario. Bulletin d'Histoire de la culture matérielle, n.23, p.13$24,1986$.

HANNON, Thomas J. The cemetery: a field of artifacts. In: WARD, Albert E., ed. Fongotten places and things: archaeological perspectives on American History. Contributions to Anthropological Studies n.6, Center for Anthropological Studies, Albuquerque. 1983.

HAUSER, Arnold. História Social da literatura e da arte. 2.ed. São Paulo: Mestre Jou, 1972. v.2.

HOULBROOKE, Ralph, ed. Death, ritual and bereavement. London: Routledge/Social History Society, 1989.

HUMPHREYS, S. C.; KING, Helen, eds. Mortality and immortality: the anthropology and archaeology of death. New York: Academic Press, 1981.

HUNTINGTON, Richard; METCALF, Peter. Celebrations of deatb: the anthropology of mortuary ritual. 2.ed. Cambridge: Cambridge University Press, 1992.

JEANE, D. Gregory. The Upland South Folk Cemetery Complex: some suggestions of origin. In: MEYER, Richard E., ed. Cemeteries \& gravemarkers: voices of American culture. Ann Arbor: UMI Research Press, 1989.

JORDAN, Terry. The roses so red and the Lilies so fair: Southern Folk Cemeteries in Texas. Southwestern bistorical quarterly, v.8, n.3, p.227-58, 1980. 
KJOLBYE-BIDDLE, B. A cathedral cemetery: problems in excavation and interpretation. World archaeology, n.7, p.87-108, 1976.

LANPHEAR, Kim M. Frequency and distribution of enamel hypoplasias in a historical skeletal sample. American joumal of Physical Anthropology, n.81, p.35-43, 1990.

LITTLE, Barbara J.; LANPHEAR, Kim M.; OWSLEY, Douglas W. Mortuary display and status in a nineteenth-century Anglo-American cemetery in Manassas, Virginia. American Antiquity, v.57, n.3, p.397-418, 1992.

LLEWLLYN, Nigel. The art of death: visual culture in the English death ritual, 1500-1800. London: Victoria and Albert Museum, 1992.

LOBO, Eulalia Maria Lahmeyer. História do Rio de Janeiro: do capital comercial ao capital industrial e financeiro. Rio de Janeiro: IBMEC, 1978, v.2

LOUREIRO, Maria Amélia Salgado. Origem bistórica dos cemitérios. São Paulo: Secretaria de Serviços e Obras, 1977.

MACHADO, Roberto et al. Danação da norma: Medicina social e constituição da psiquiatria no Brasil, Rio de Janeiro: Graal, 1978. (Saber e Sociedade, 3).

MARTINS, José de Souza, org. A morte e os mortos na sociedade brasileira. São Paulo: Hucitec, 1983.

MCGUIRE, Randall. Dialogues with the dead: ideology and the cemetery. In: LEONE, M. P; POTTER JR.,P. B., eds., The recovery of meaning: Historical archaeology in the Eastern United States. Washington: Smithsonian Institution, 1988. p.435-80.

MEIHY, José Carlos Sebe Bom; LEVINE, Robert. Até o encontro na eternidade. Cadernos de pesquisa, n.1, (Guaratinguetá: Museu Rodrigues Alves), 1987.

MILBAUER, John. Southern folk traits in the cemeteries of Northeastern Oklahoma. Southern folklore, v.46, n.2, p.175-85, 1989.

NABUCO, Joaquim. A intervenção estrangeira durante a revolta de 1893. In: Obras completas de Joaquim Nabuco. São Paulo: Inst. Progresso Editorial, 1949a. v.2, p.145-262.

O Marechal Floriano e a Revolta. In: Obras Completas de Joaquim Nabuco. São Paulo: Inst. Progresso Editorial, 1949b. v.2, p.263-75.

OSBORNE, Brian S. The cemeteries of Midland District of Upper Canada: a note on mortality in a frontier society. Pioneer America, v.6, n.1, p.46-55, 1974.

OWSLEY, Douglas W. et al. Demography and pathology of an urban slave population from New Orleans. American joumal of Physical Antbropology, n.74, p.185-97, 1987.

PARRINGTON, Michael. Cemetery archaeology in the urban environment: a case study from Philadelphia. In: STASKI, E., ed. Living in the cities: current research in urban Archaeology, p.56-64, 1987. (Society of Historical archaeology, Special Publication Series, 5). 
PATTERSON, Nancy Lou. Open secrets: fifteen masonic and orange lodge gravemarkers in Waterloo and Wellington Counties, Ontario. Bulletin d'Histoire de la Culture Matérielle, n.23, p.42-47, 1986.

PEARSON, Michael Parker. Mortuary practices, society and ideology: an ethnoarchaeological study. In: HODDER, Ian, ed. Simbolic and structural Archaeology. Cambridge: Cambridge University Press, 1982. p.99-113.

PENNY, Nicholas. Mourning. London: Victoria and Albert/Crown, 1981.

POCINS, Gerald. The transformation of the traditional Newfoundland Cemetery: institutionalizing the secular dead. Bulletin d'Histoire de la culture matérielle, n.23, p.25-34, 1986.

QUEIRÓS, Maria Isaura Pereira de. Cultura, sociedade nural, sociedade urbana no Brasil. Rio de Janeiro: Livros Técnicos e Científicos/São Paulo: Edusp, 1978.

QUEIROZ, Sueli Robles Reis de. Os radicais da República: Jacobinismo, ideologia e ações. 1893-1897. São Paulo: Brasiliense, 1986.

O Jacobinismo na Primeira República: reforma ou revolução? In: CONGRESSO NACIONAL DE HISTÓRIA DA PROPAGANDA, PROCLAMAÇÃO E CONSOLIDAÇÃO DA REPÚBLICA. Rio de Janeiro: IHGB, 1989. Anais. v.2, p. 227-38. 1989

RAGON, Michel. L'espace de la mort: essai sur l'architecture, la décoration et l'urbanisme funéraire. Paris: Albin Michel, 1981.

REIS, João José. A morte é uma festa: ritos fúnebres e revolta popular no Brasil do século XIX. São Paulo: Companhia das Letras, 1991.

RICHARDSON, Bill. Quaker burial grounds: plainness texts from community and family in Dutchess County, New York. Material culture, v.25, n.1, p.37-48, 1993.

RIDLEN, Susanne S. Funerary. Art in the 1890's: a reflection of culture. Pioneer American society transactions, n.6, p.27-35, 1983.

RODRIGUES, José Carlos. O Tabu da morte. Rio de Janeiro: Achiamé, 1983.

RODWELL, Warwick. The Archaeology of religious places: churches and cemeteries in Britain. Philadelphia: University of Pennsylvania Press, 1989.

SEXTON, Rocky. Don't let the rain fall on my face: French Louisiana graveshouses in an anthropo-geographical context. Material culture, v.23, n.3, p.31-46, 1991.

SHANKS, Michael; TILLEY, Christopher. Re-constructing Archaeology: theory and practice. Cambridge: Cambridge University Press, 1987.

SLATER, James A. The colonial burying grounds of Eastern Connecticut and the men who made them. Connecticut: Archon Books,1987.

STANNARD, David E. The puritan way of deatb: a study in religion, culture and social change. Oxford: Oxford University Press, 1977. 
STONE, Gaynell. Material evidence of ideological and ethnic choice in Long Island gravestones 1670-1800. Material culture, v.23, n.3, p.1-29, 1991.

STONE, Patricia; RUSSEL, Lynn. Observations on figures, human and divine, on 19th. century Ontario gravestones. Bulletin d'Histoire de la culture matérielle, n.24, 1986.

TAYLOR, Lou. Mouming etiquette: hints to persons in mourning, including the best social usage as to cards, costume, period of mourning, appropriate jewelry, etc. New York: Fowler Brothers, 1980.

Mourning dress: a costume and Social History. London: George Allen \& Unwin, 1983.

TENENTI, Alberto. La vie et la mort à travers l'art du XVe siècle. Paris: Colin, 1952.

TRASK, Deborah. Life bow short, eternity bow long: gravestone carving and carvers in Nova Scotia. Halifax: Nova Scotia Museum. 1978.

TRASK, Deborah; MC NABB, Debra. Carved in stone: material evidence in the graveyards of Kings County, Nova Scotia. Bulletin d'Histoire de la culture matêrielle, n.23, p.35-42, 1986

URBAIN, Jean Didier. La Société de Conservation: étude sémiologique des cimetières d'Occident. Paris: Payot, 1978.

VALLADARES, Clarival do Prado. Arte e sociedade nos cemitérios brasileiros. Rio de Janeiro: Conselho Federal de Cultura, 1972. 2v.

VASCONCELLOS, Zacharias de Goes. Legislação sobre a empresa funeräria e os cemitérios da cidade do Rio de Janeiro. Rio de Janeiro: Typ. da Escola de Serafim José Alves, 1878.

VIEIRA FAZENDA, J. Antiqualhas e memórias do Rio de Janeiro. Revista do IHGB. t.86, v.140, 1921.

VOVELLE, Michel. Vision de la mort et de l'au-delà en Provence, d'après les autels des âmes du Purgatoire. Paris: Colin, 1970.

Mourir autrefois. Paris: Gallimard/Julliard, 1974.

Piété baroque et déchristianisation: les attitudes devant la mort en Provence au XVIIIème siècle. Paris: Seuil, 1978.

La mort et l'Occident. Paris: Gallimard, 1983.

Ideologias e mentalidades. São Paulo: Brasiliense, 1987.

L'beure du grand passage: chronique de la mort. Paris: Gallimard, 1993.

WATTERS, David R. Excavations at the Hamey Site Slave Cemetery, Montserrat, West Indies. Annals of Carnegie Museum, n.56, p.289-318, 1987.

WURST, Lou Ann. "Employees must be of moral and temperate habits": rural and urban elite ideologies. In: MCGUIRER, H.; PAYNTER, R. The arcbaeology of inequality. Oxford/Cambridge: Blackwell, 1991. p.125-49. 
Signos escatológicos

Cemitério do Catumbi

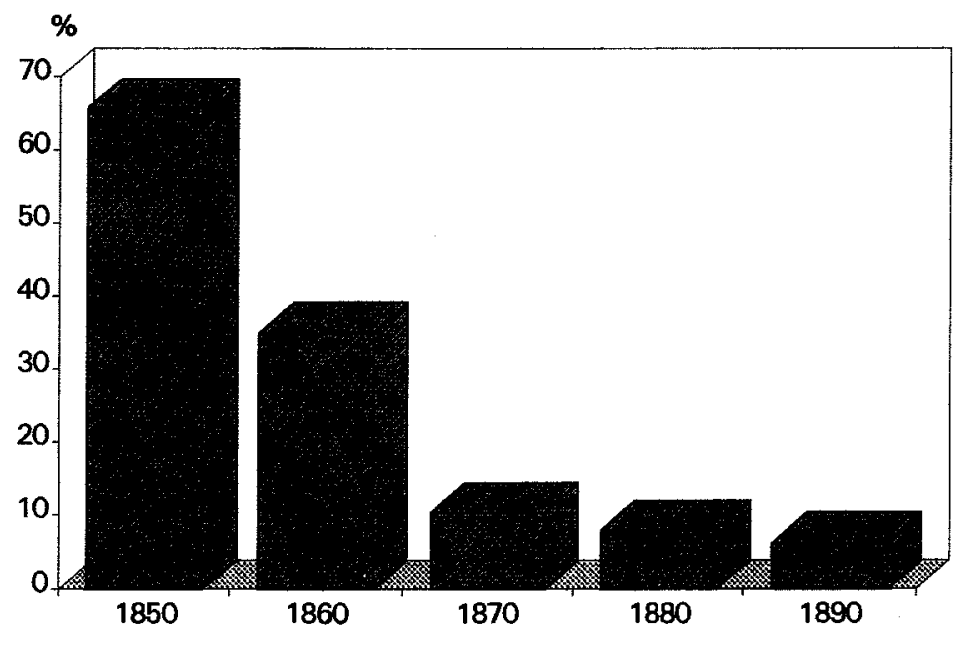

gráfico 2

Signos escatológicos

Cemitério São João Batista

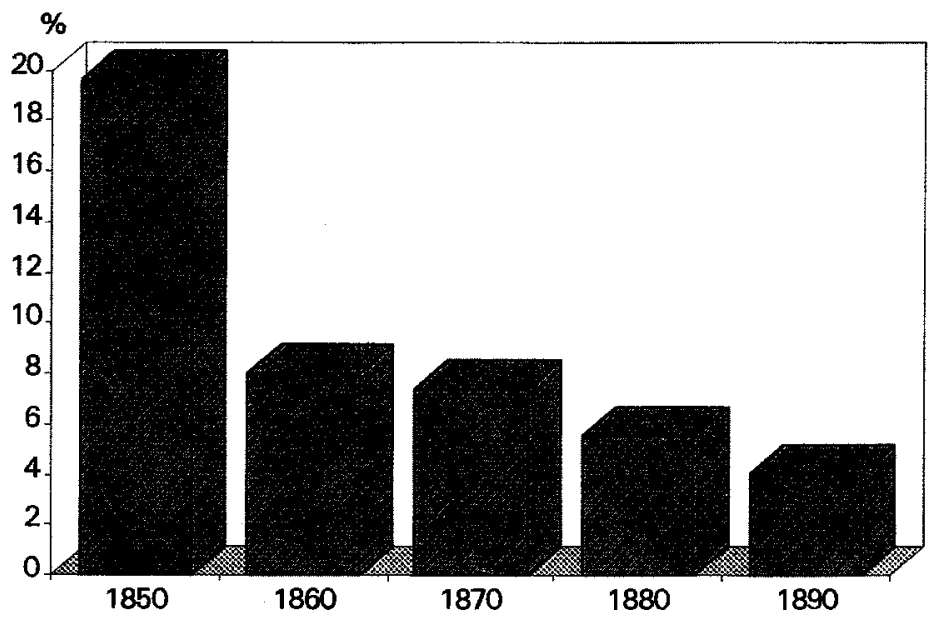


Signo "cruz sobre pedras"

Cemitério do Catumbi

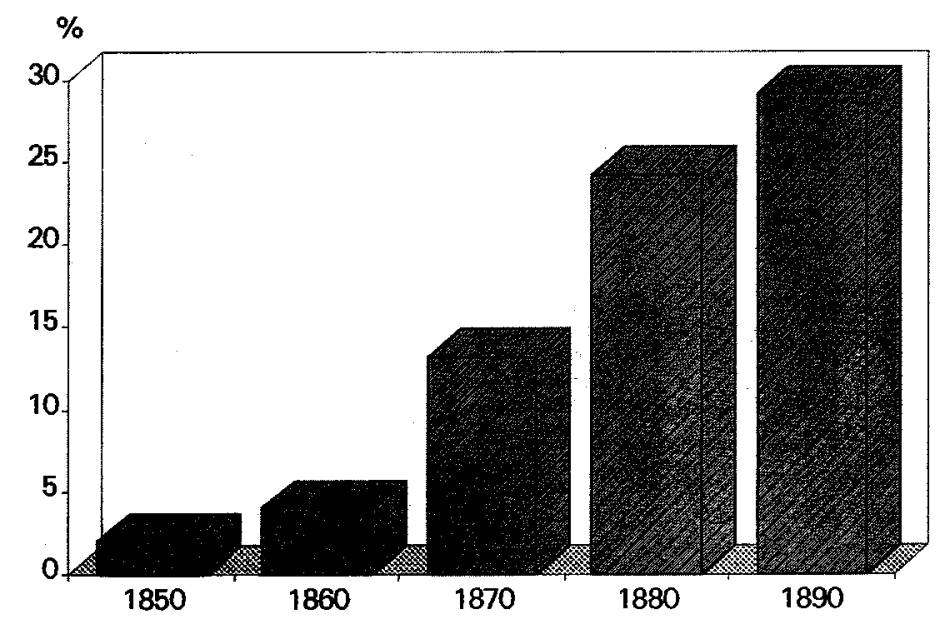

gráfico 4

Signo "cruz sobre pedras"

Cemitério São João Batista

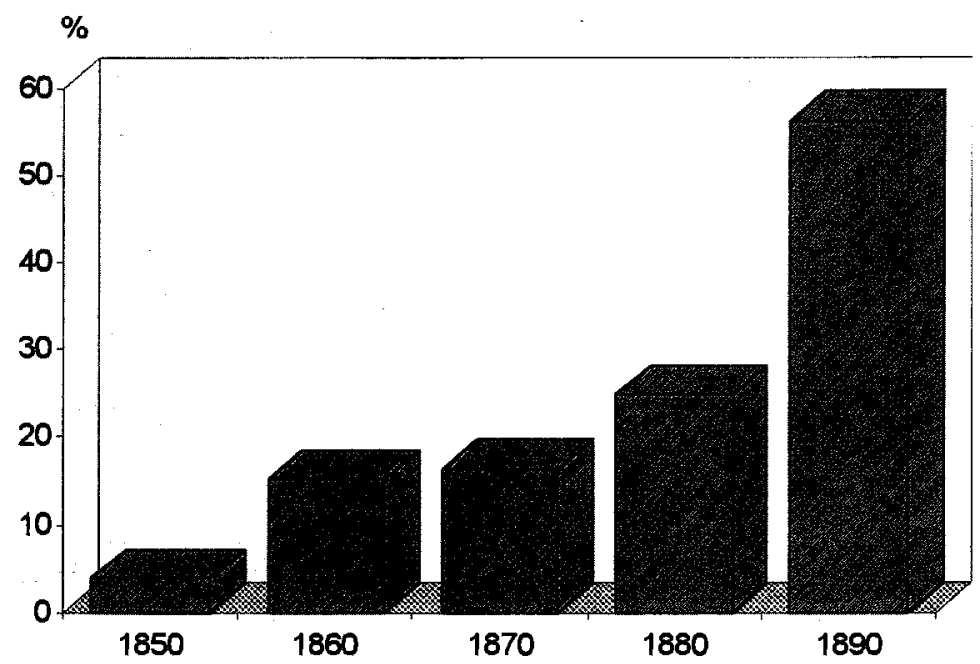

gráfico 5 


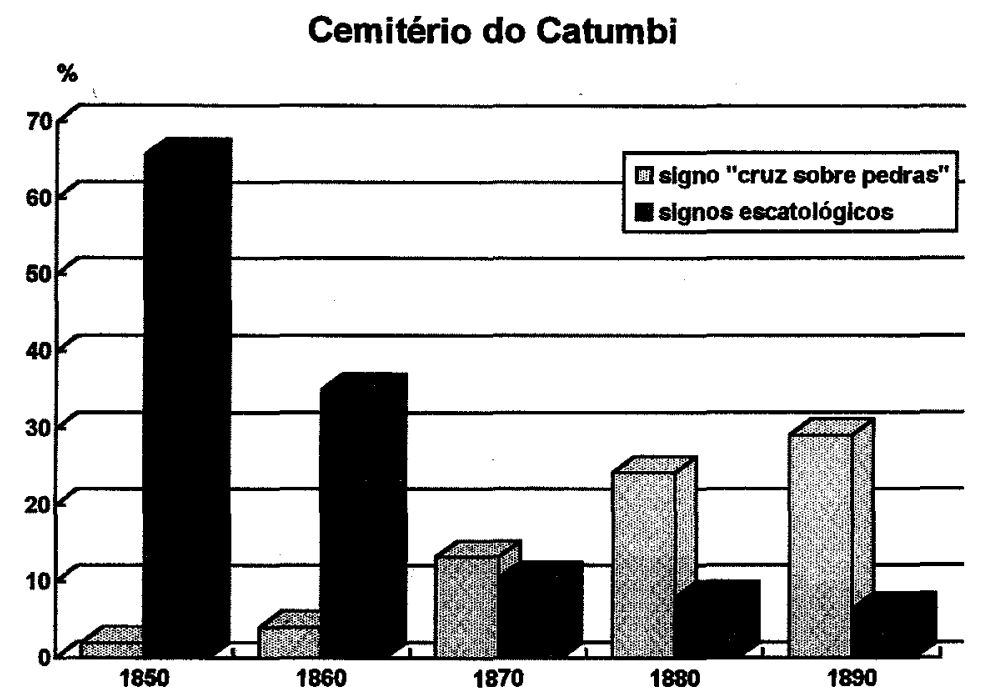

gráfico 6

\section{Cemitério São João Batista}

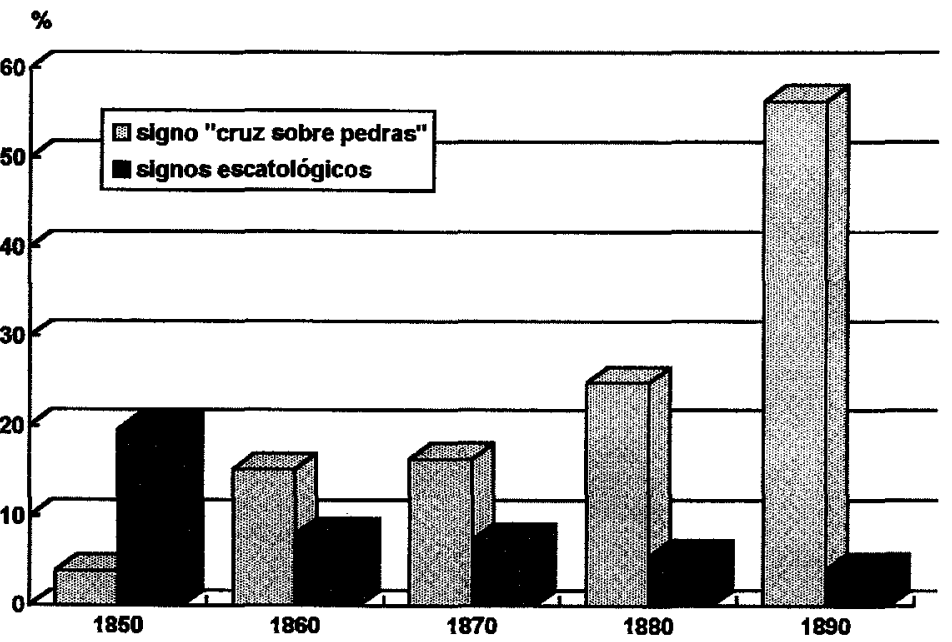




\section{Freqüências Comparadas Cemitério do Catumbi}
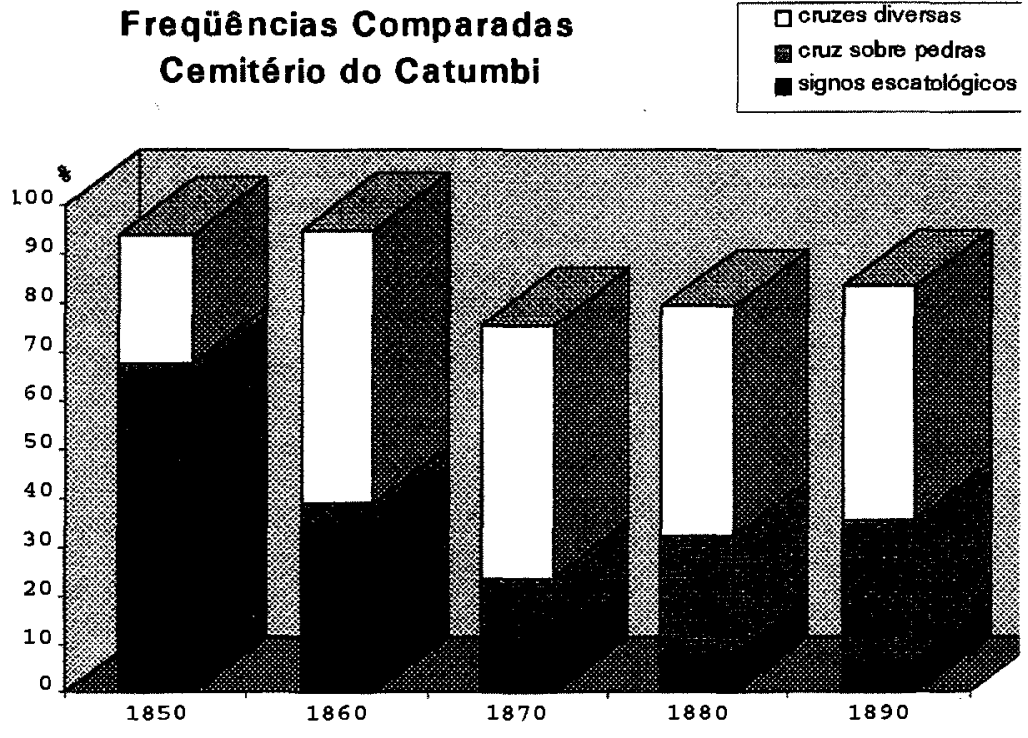

gráfico 8
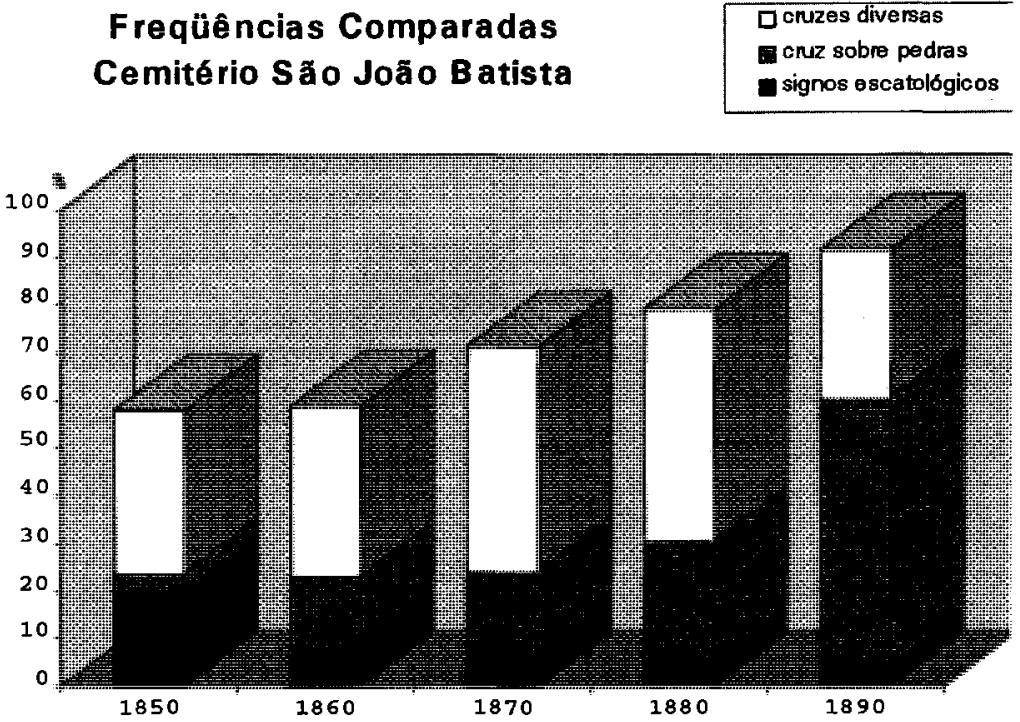

gráfico9 


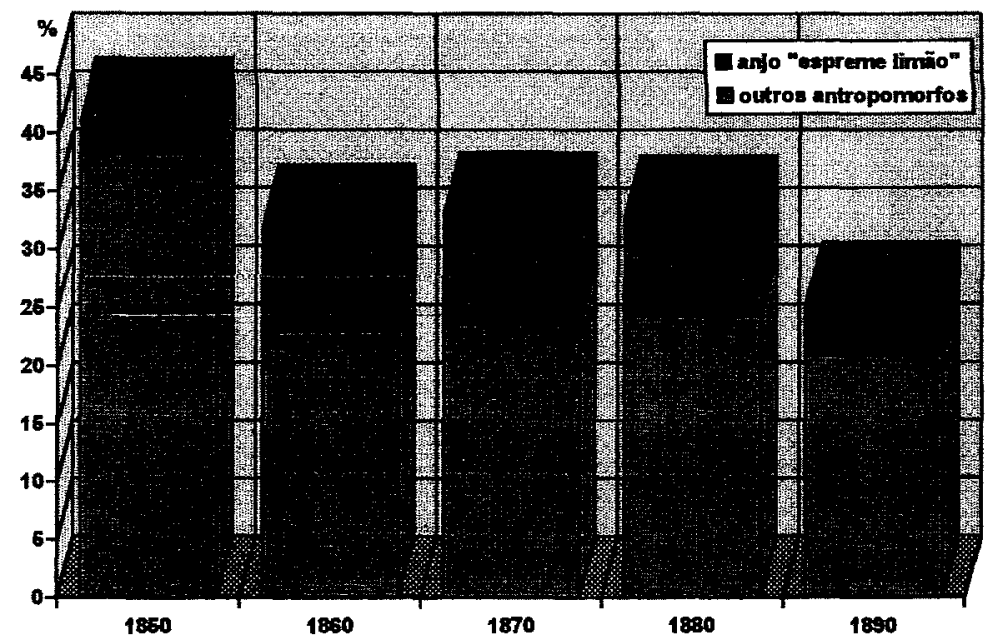

gráfico 10

Signos Antropomorfos

Cemitério São Joảo Batista

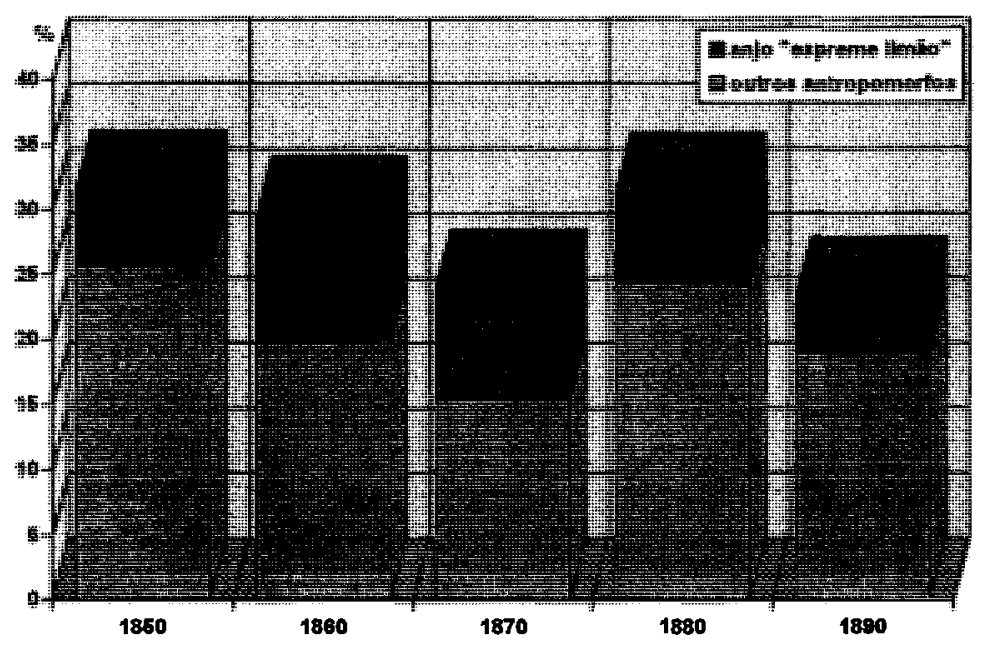

$126 \quad$ gráfico 11 

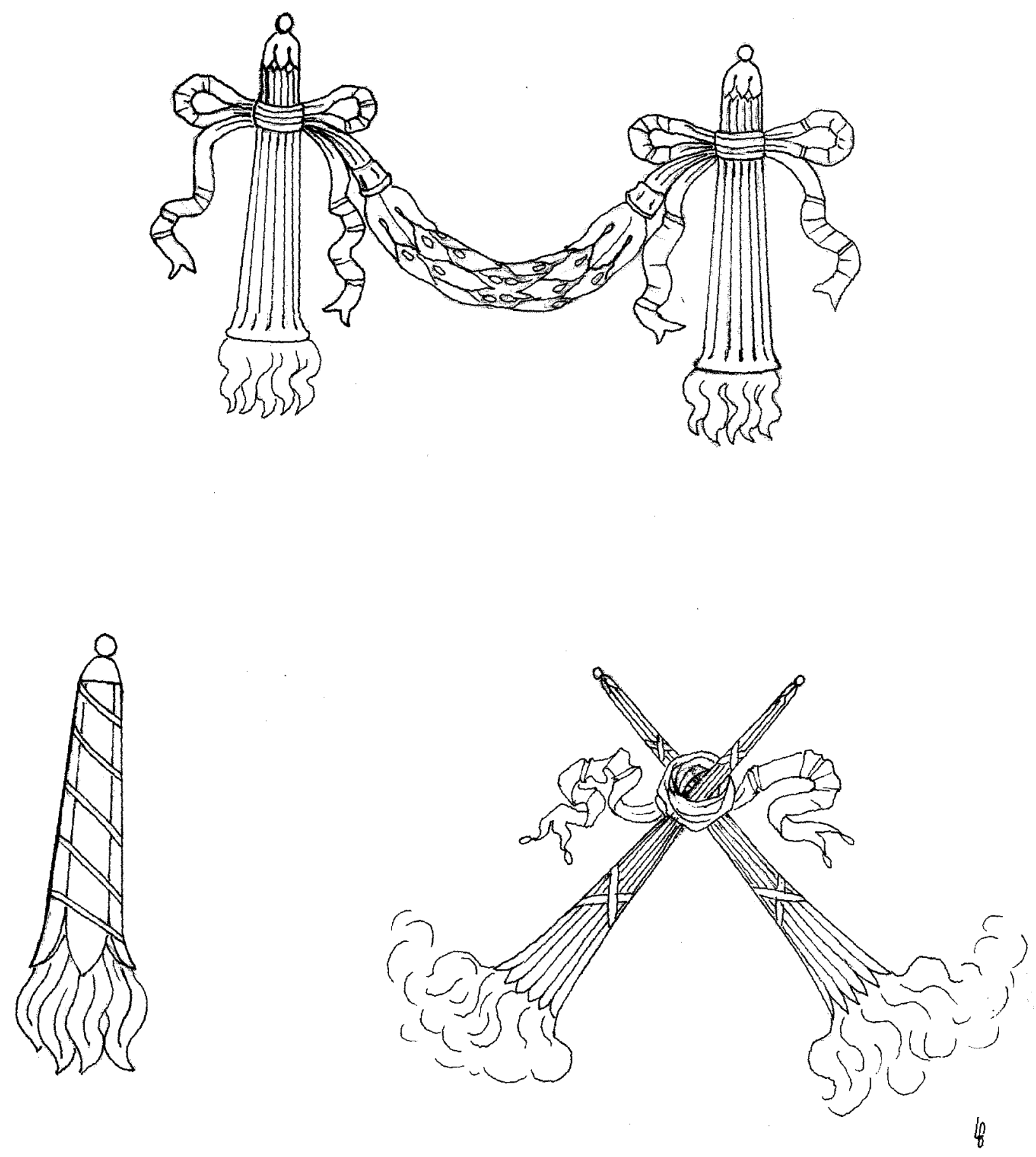

Prancha 1: Signos escatológicos

Tochas voltadas para baixo - Cemitério do Catumbi

Desenhos: Maria Lilia Gomide da Silva 

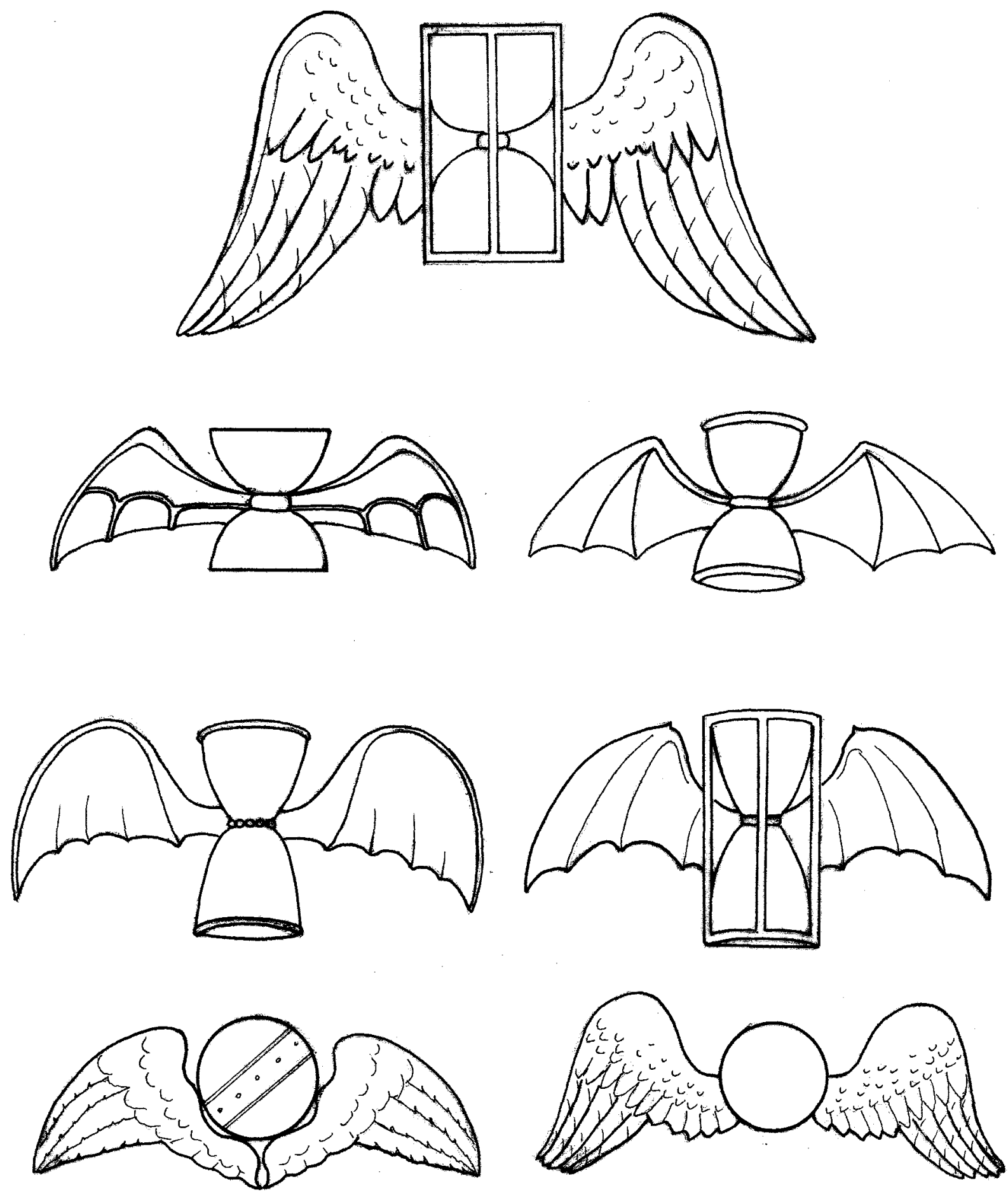

Prancha 2: Signos escatológicos

128

Ampulhetas e globos alados - Cemitério do Catumbi Desenhos: Maria Lilia Gomide da Silva 

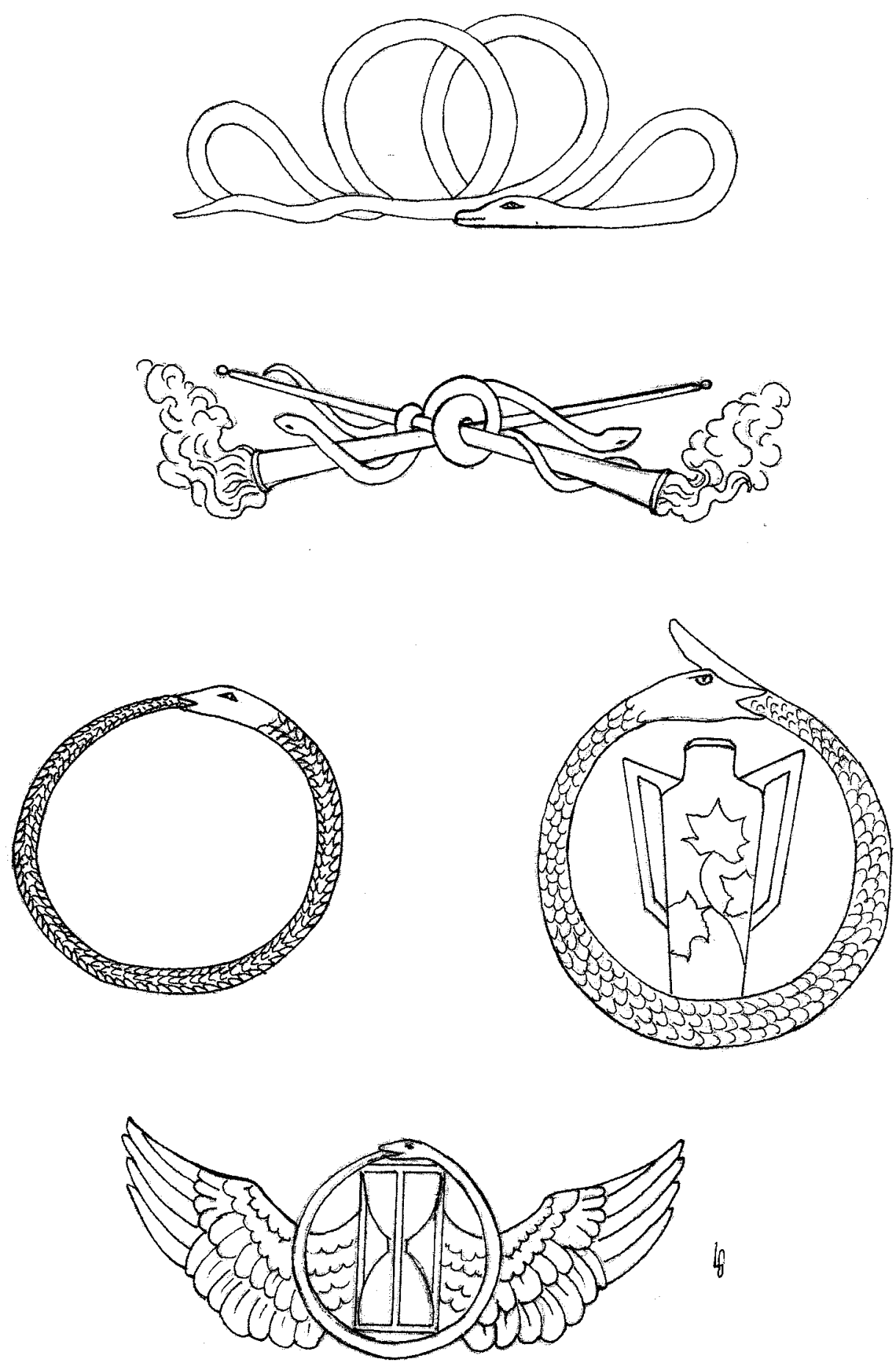

Prancha 3: Signos escatológicos

Serpentes - Cemitério do Catumbi

Desenhos: Maria Lilia Gomide da Silva 

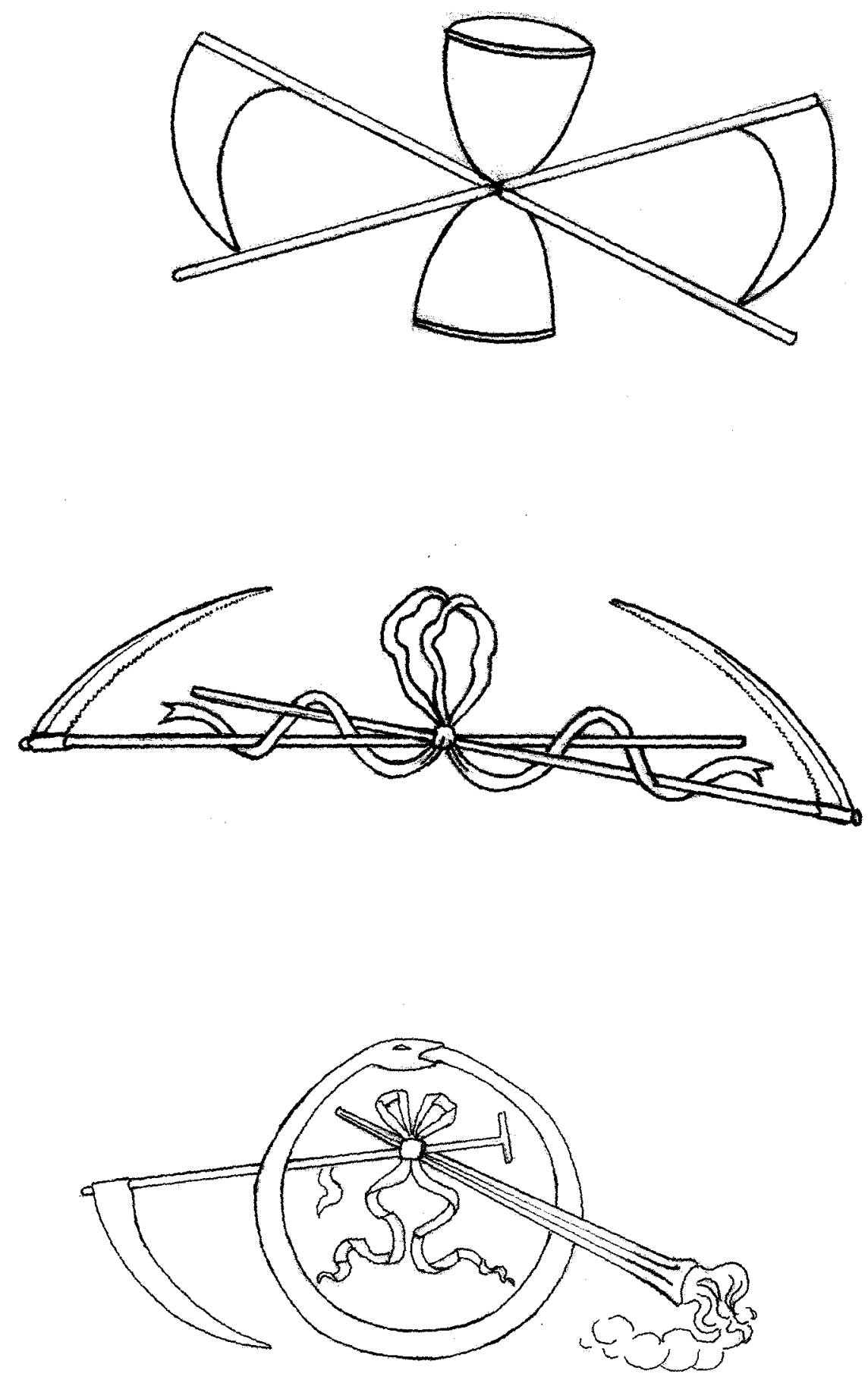

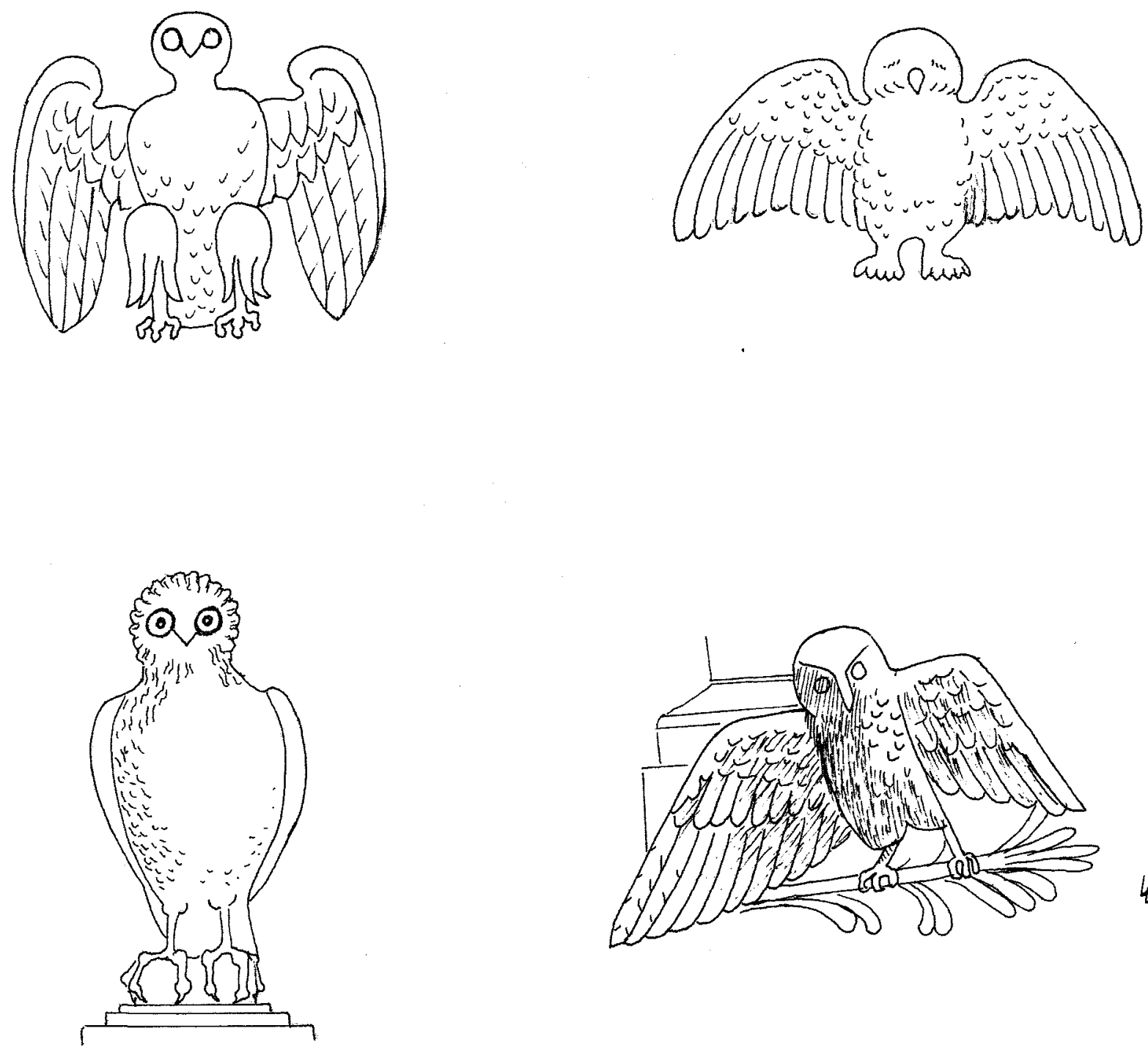

Prancha 5: Signos escatológicos

Corujas - Cemitério do Catumbi

Desenhos: Maria Lilia Gomide da Silva 

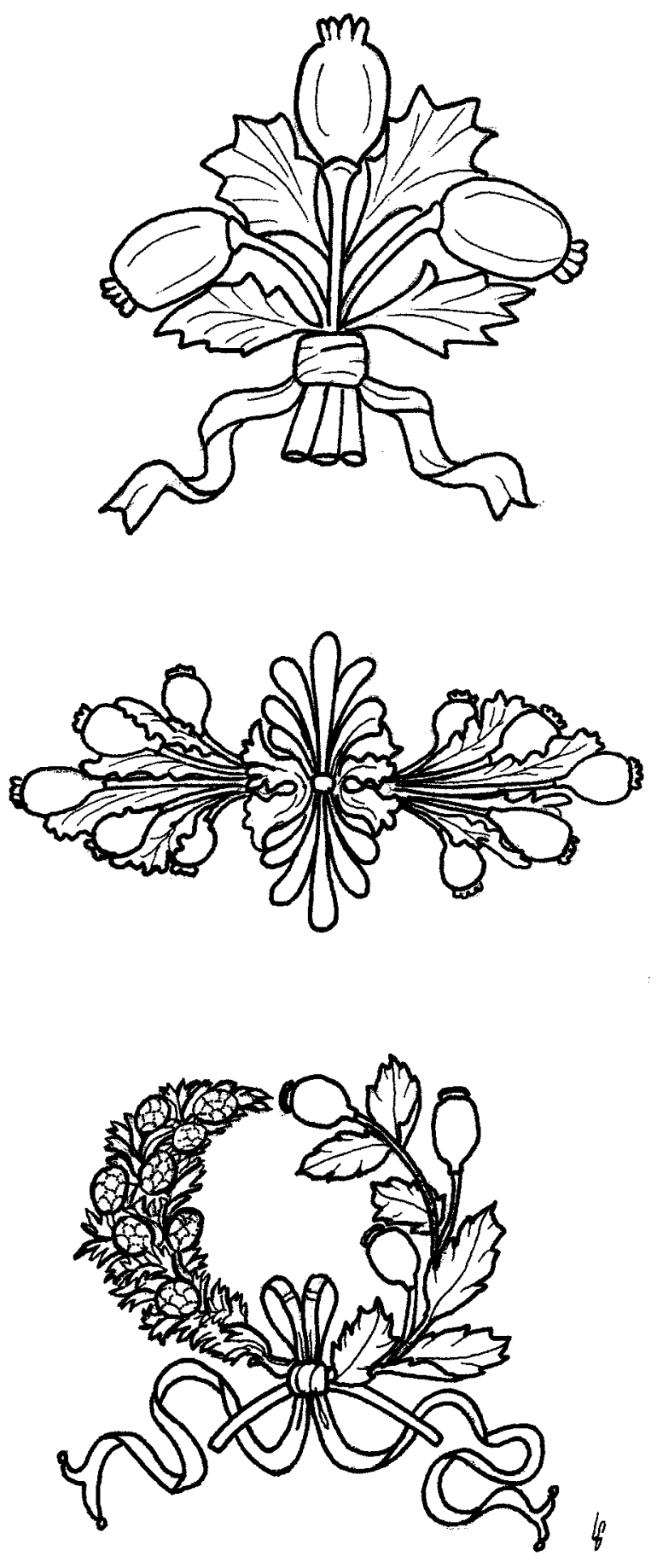

Prancha 6: Signos escatológicos

Papoulas - Cemitério do Catumbi 

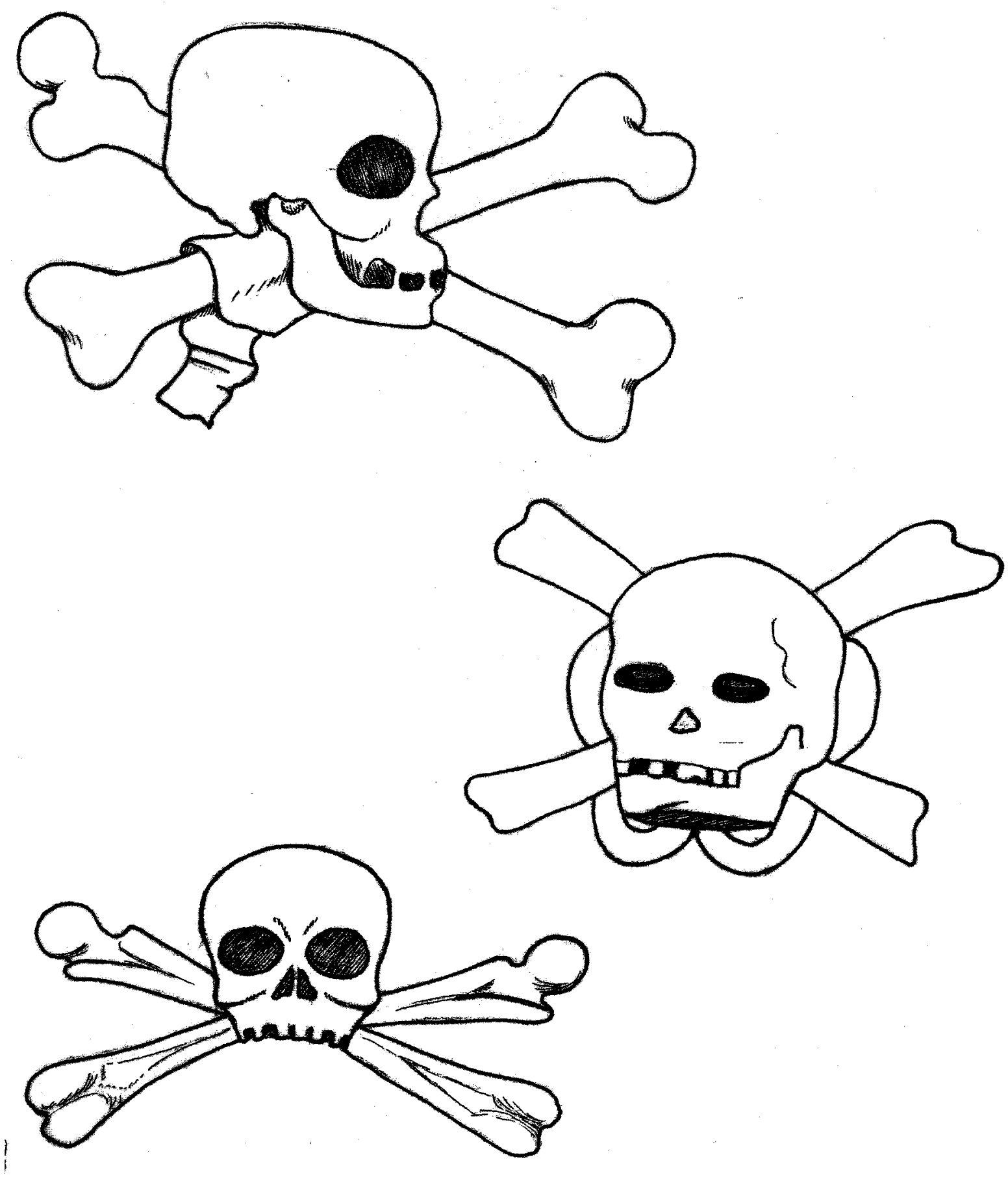

Prancha 7: Signos escatológicos

Caveiras - Cemitério do Catumbi

Desenhos: Maria Lilia Gomide da Silva 

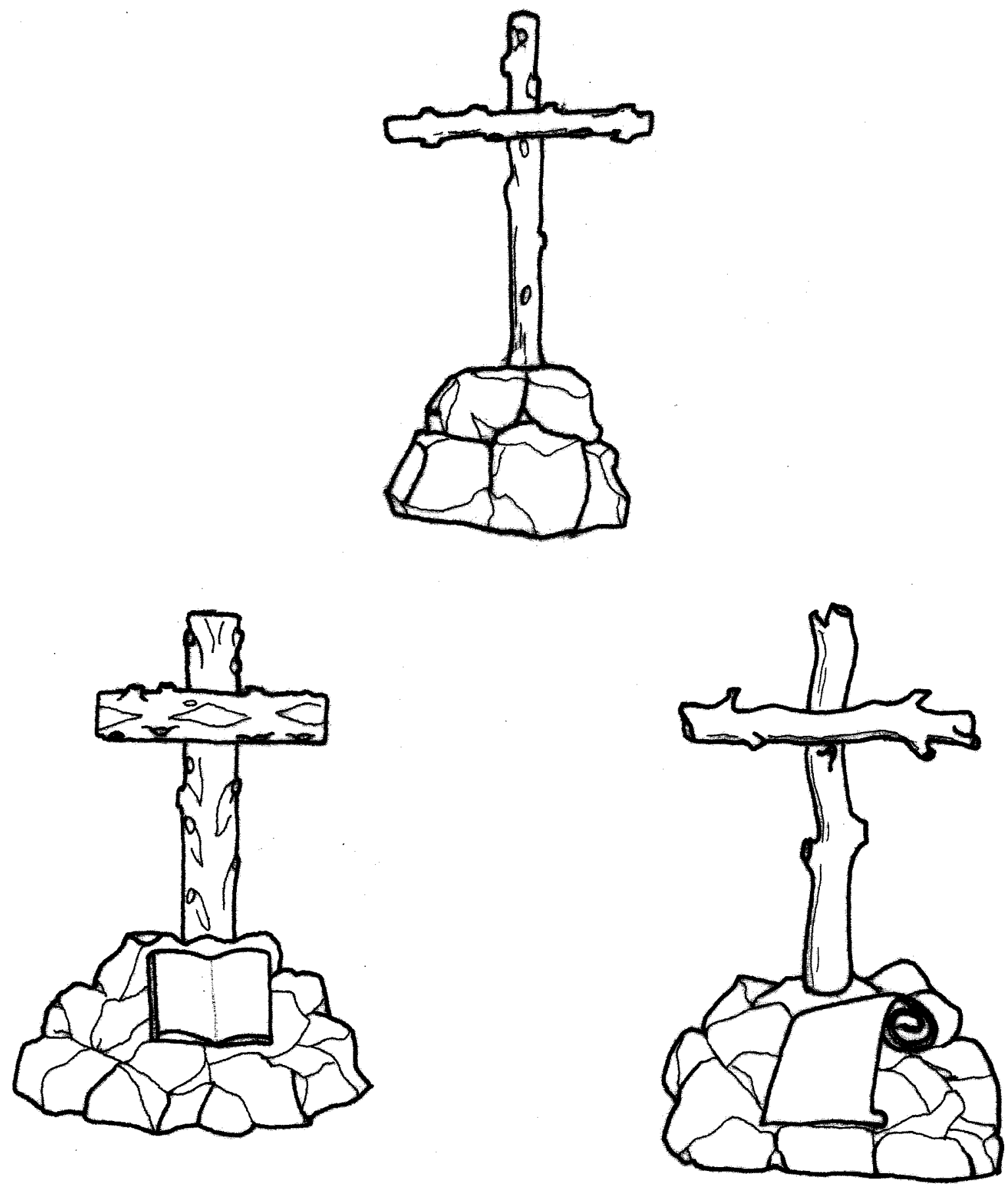

4

134

Prancha 8: Signo "cruz sobre pedras"

Desenhos: Maria Lilia Gomide da Silva 


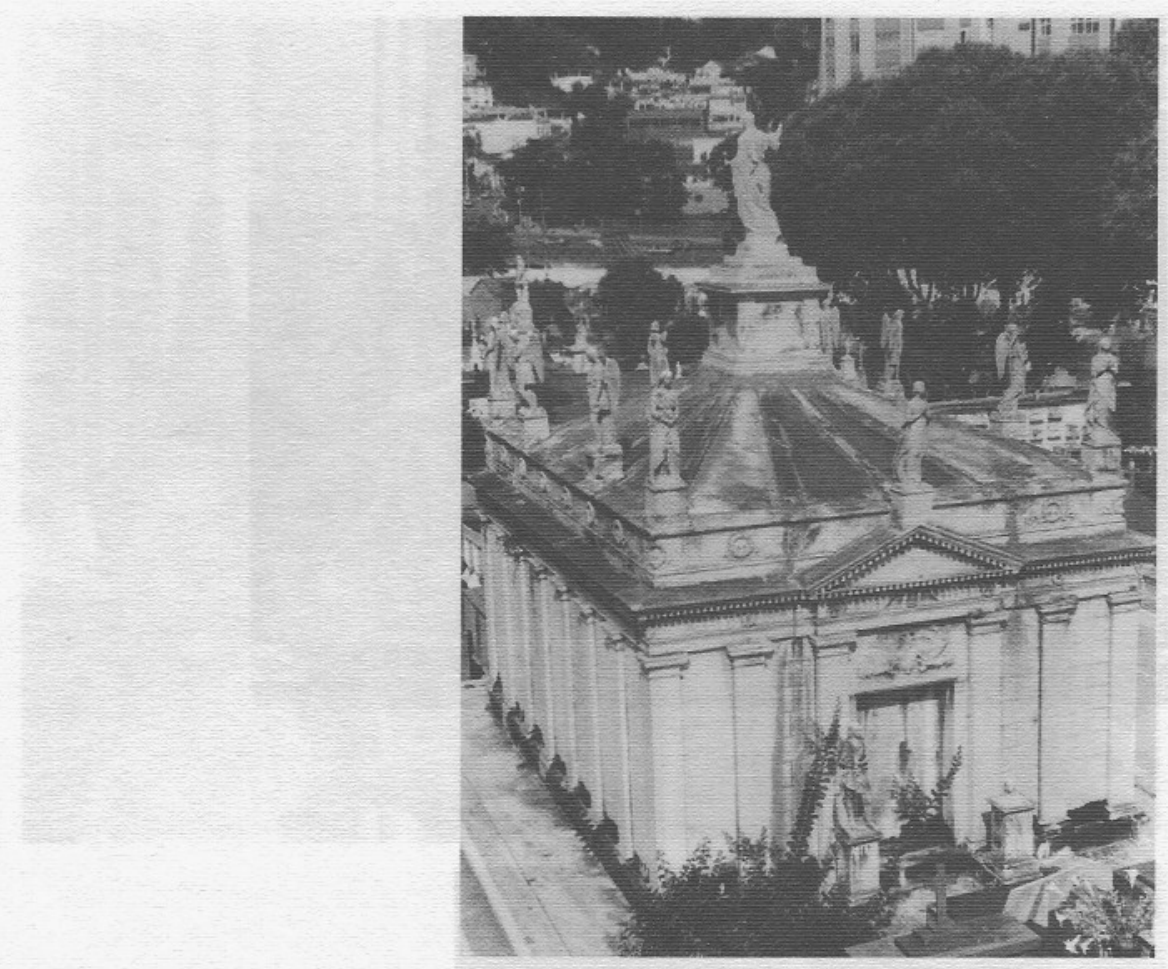

Foto 1: Mausoléu da ala monumental do Cemitério do Catumbi, em vista posterior. Esta ala foi degradada pela construção desordenada de sepulturas mais recentes. Encontra-se atualmente atuhada e os mausoléus são pouco visiveis em meio à parafernália tumular erigida à sua volta.

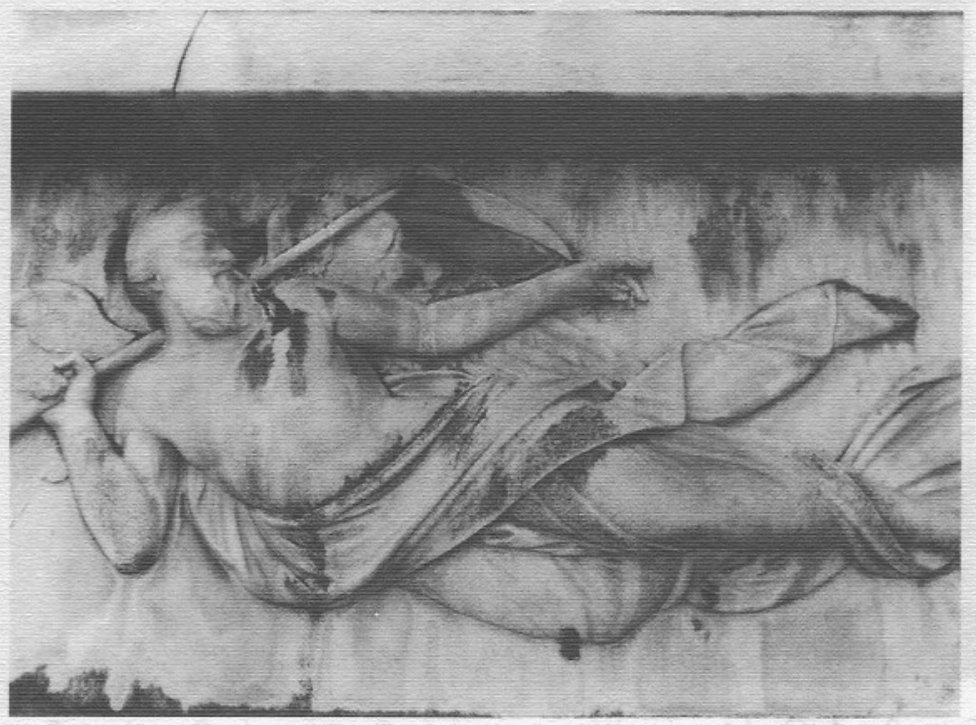

Foto 2: Detalhe do mausoléu anterior: sobre a porta principal, Cronos, o Tempo que a tudo regula e a todos devora, portando a foice, sua arma implacável. 


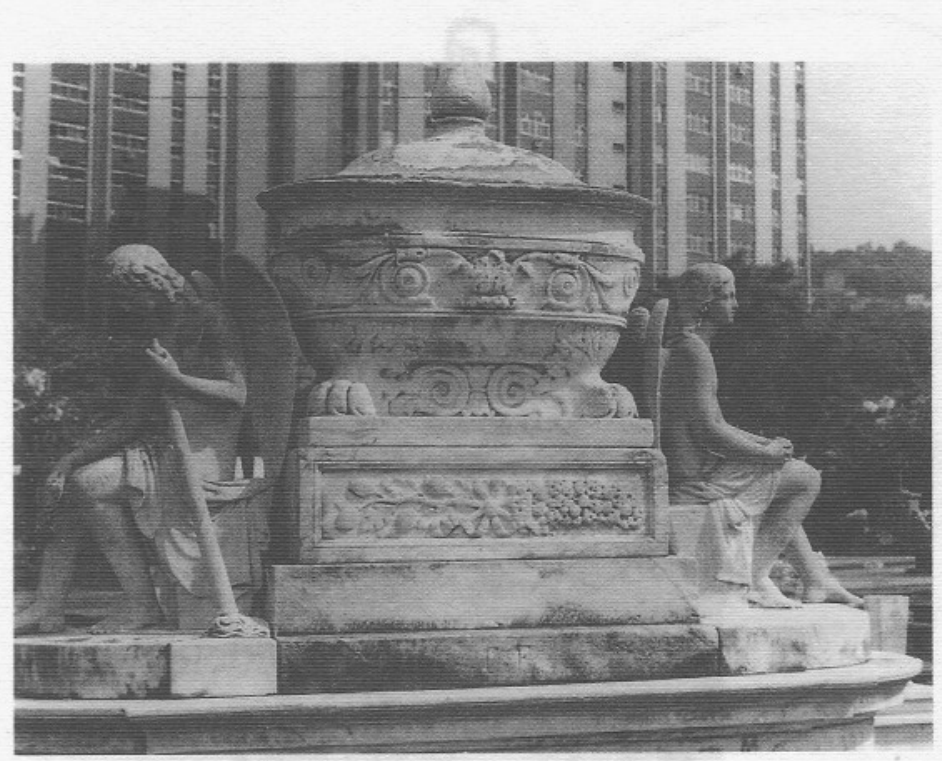

Fotos 3 e 4: Ossários da aléia principal do Cemitério do Catumbi: reflexão e melancolia na atitude dos anjos de asas fechadas e pendidas, portando tochas acesas, porém voltadas para baixo, associados a papoulas (acima) e à amputheta com asas de morcego (abaixo). 

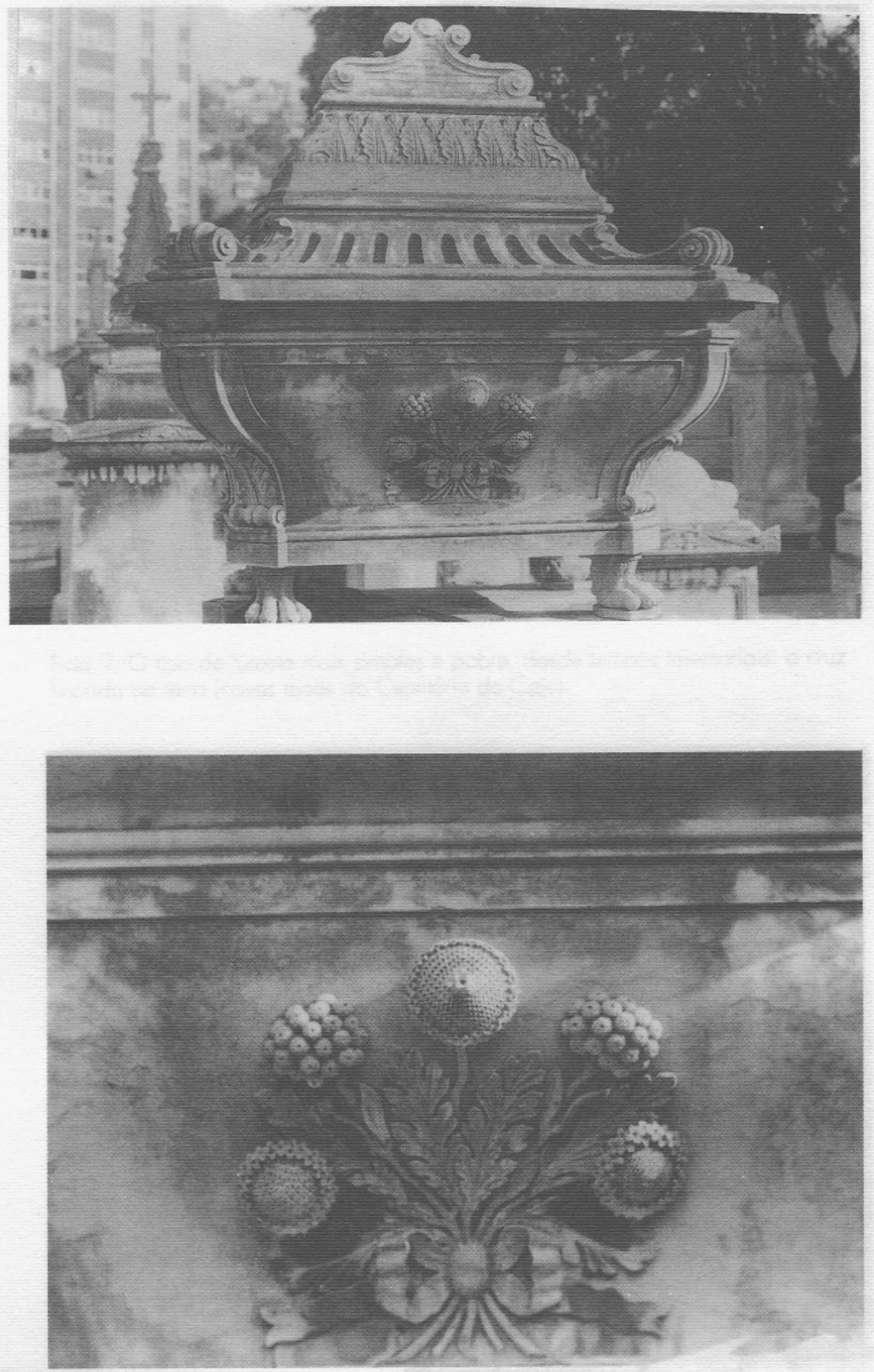

Fotos 5 e 6: Ossário da aléia principal do Cemitério do Catumbi. Em detalhe, o apuro da sua confeç̧ão. 

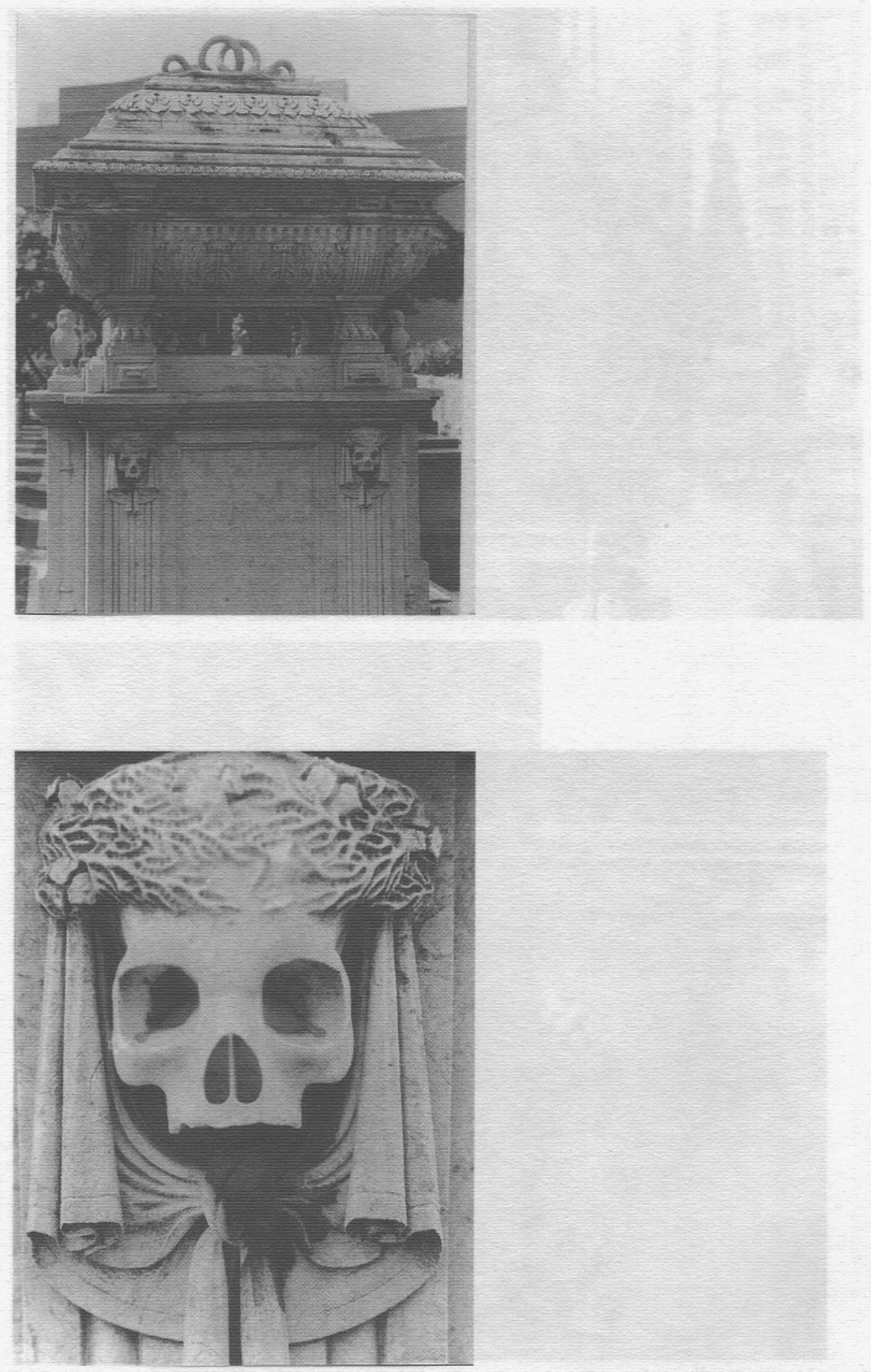

Fotos 7 e 8: Ossário da aléia principal do Cemitério do Catumbi: associação de caveiras, corvjas e serpentes. Em detalhe, o signo da morte por excelência. 


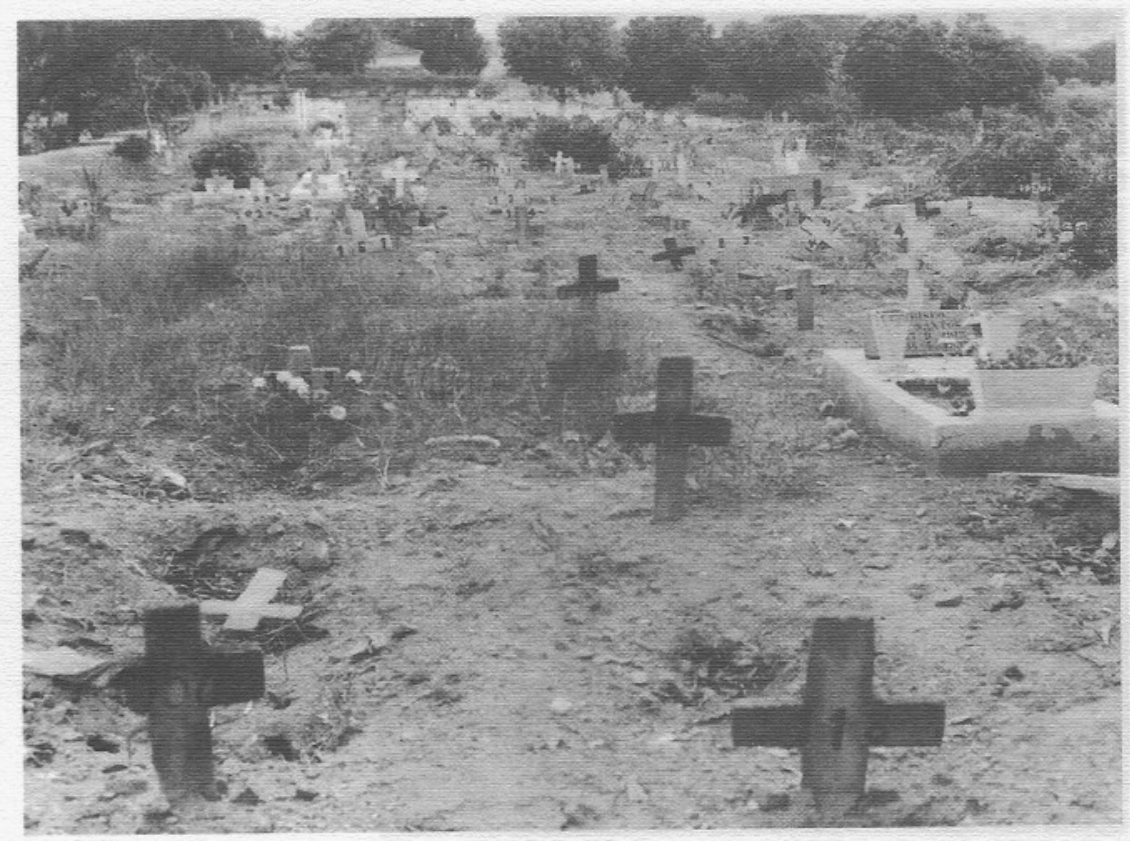

Foto 9: O tipo de túmulo mais simples e pobre, desde tempos imemoriais: a cruz fincada na terra (covas rasas do Cemitério do Caju).

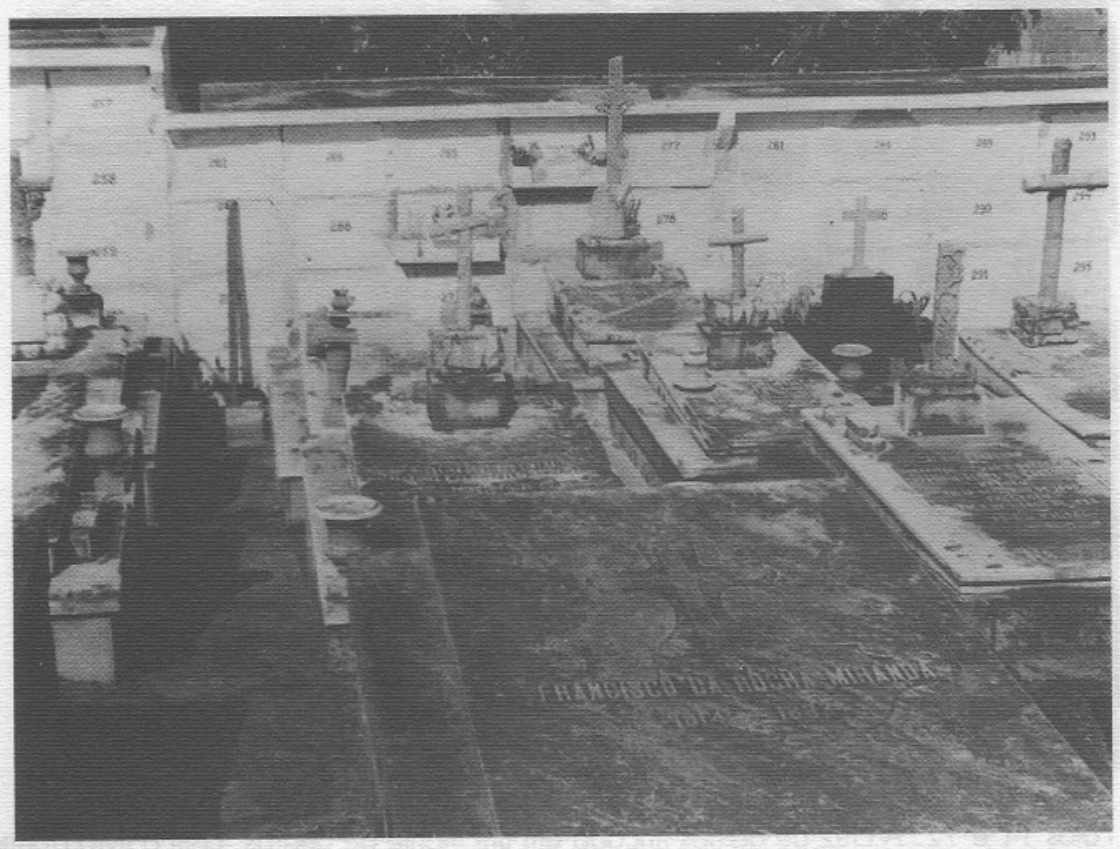

Foto 10: A feição empobrecida, banal, nivelada dos cemitérios ao final do século XIX, reproduzindo em mármore as sepulturas mais humildes que existem. 

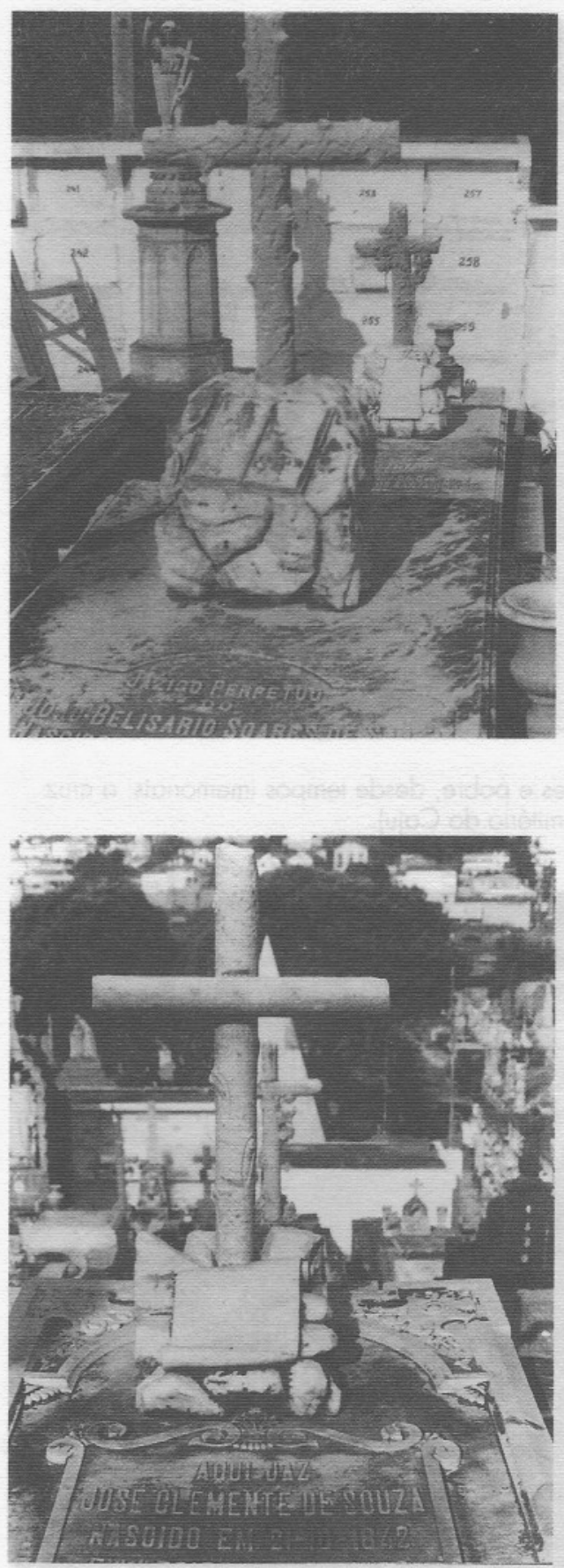

Fotos 11 e 12: A cruz de galhos fincada em um monte de pedras, com o livro aberto (acima) ou - pergaminho (abaixo) em sua base. 

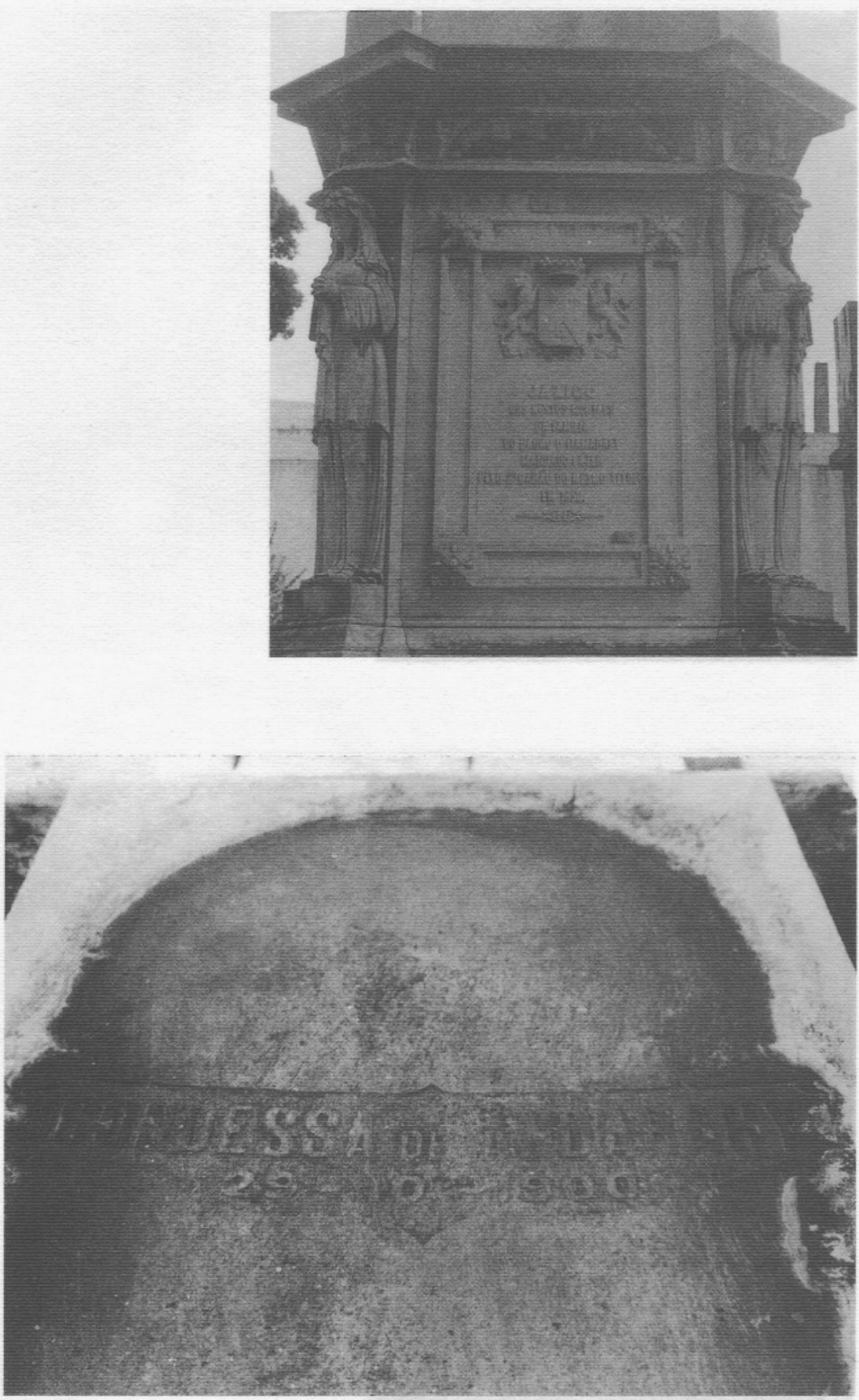

Fotos 13 e 14: O contraste notável entre as sepulturas da nobreza, antes e depois da ruptura do sistema escravista: acima, somente a base do grande mausoléu do Barão de Itamaraty, em 1858; abaixo a simplificação extrema da lápide tumular da Condessa de Andarahy, em 1900 (Cemitério do Catumbi). 

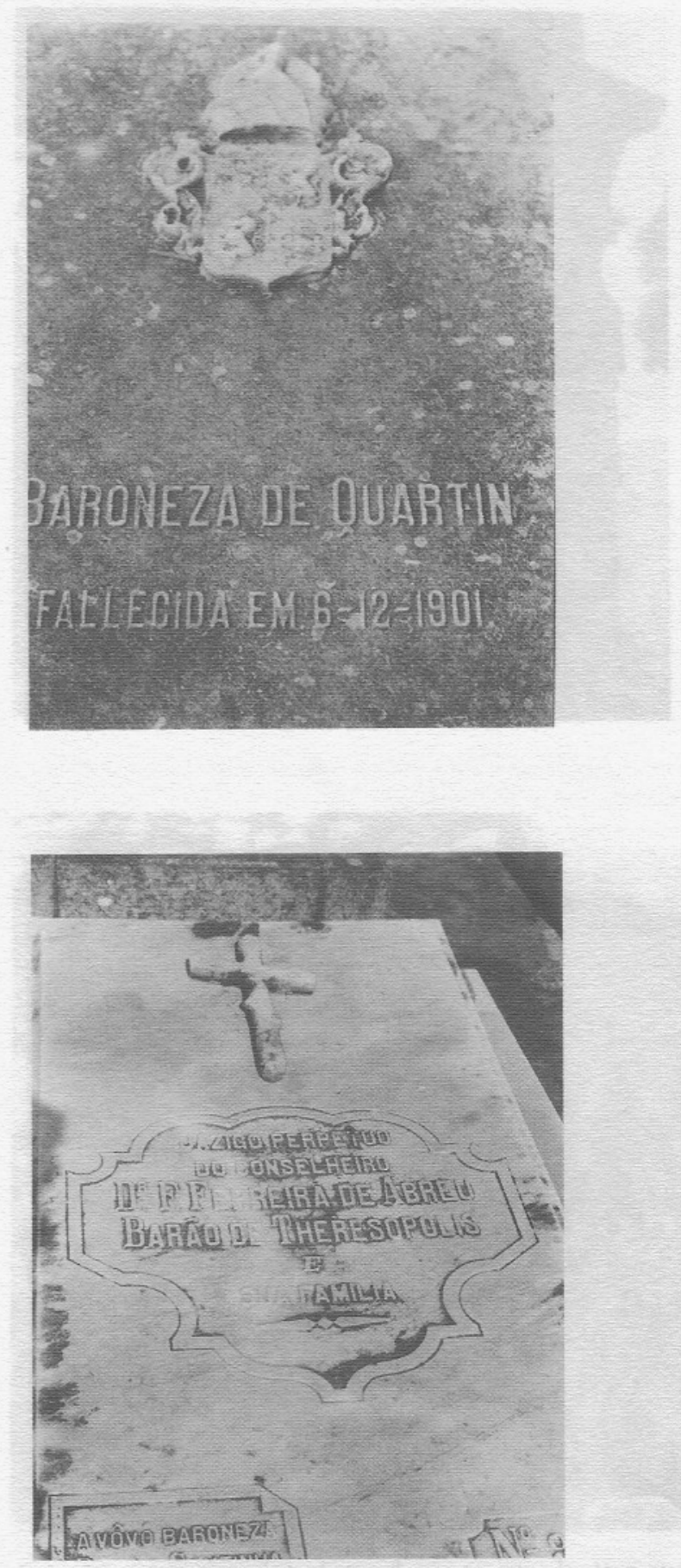

Fotos 15 e 16: Na lápide tumular da Baronesa de Quartin apenas o brasão, seu nome e a data de falecimento, em 1901 (acima). Na do Barão de Theresopolis, apenas o epitáfio e a cruz de galhos (Cemitério do Catumbi). 

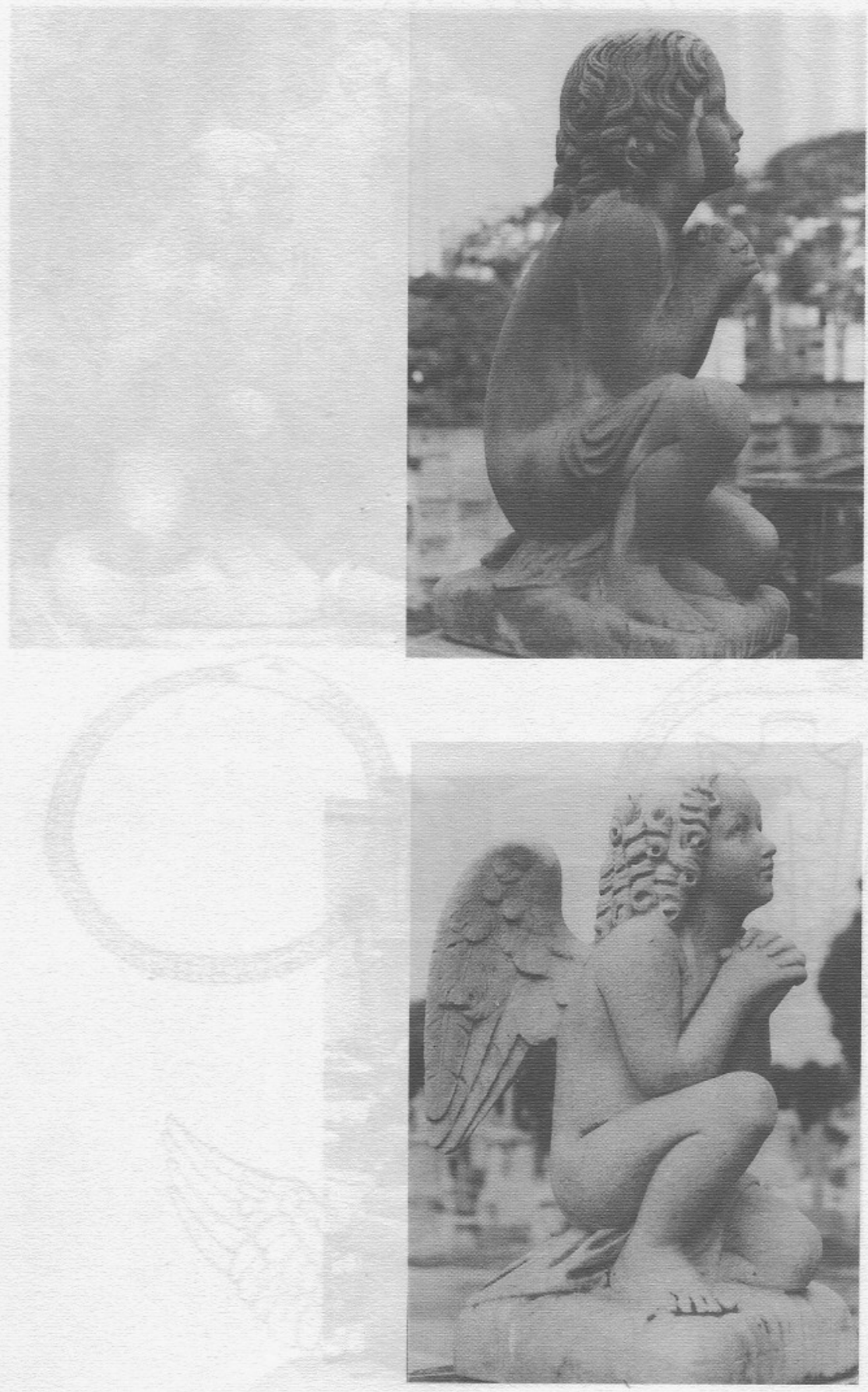

Fotos 17 e 18: $O$ anjo "espreme-limão", sem asas ou alado, que se manteve por muitas décadas no repertório dos marmoristas. 

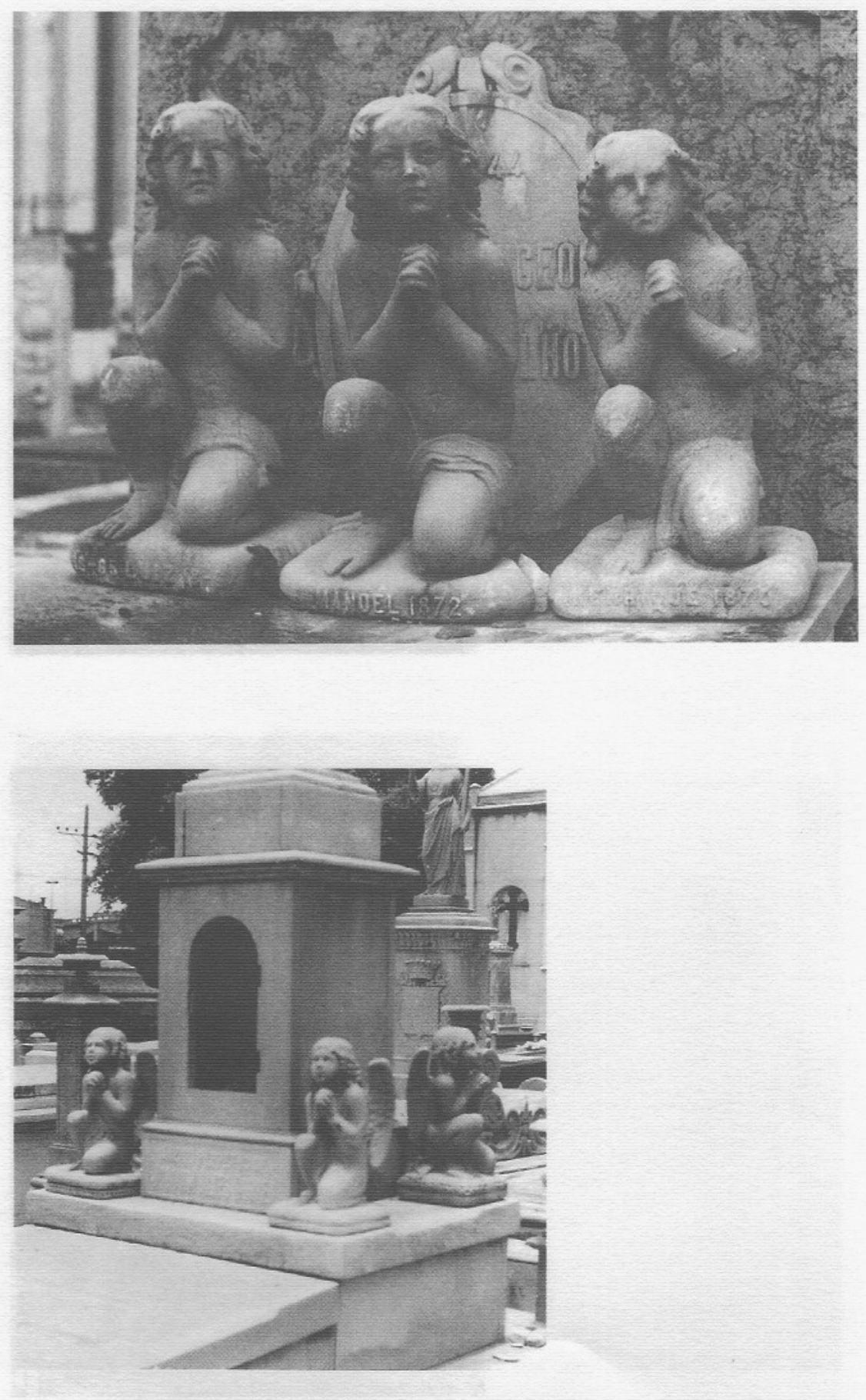

Fotos 19 e 20: A proliferação dos anjos "espreme-limão" nos cemitérios, atestando a massificação da arte tumular. Acima: Cemitério do Catumbi. Abaixo: Cemitério da VOT de N. S. do Carmo. 


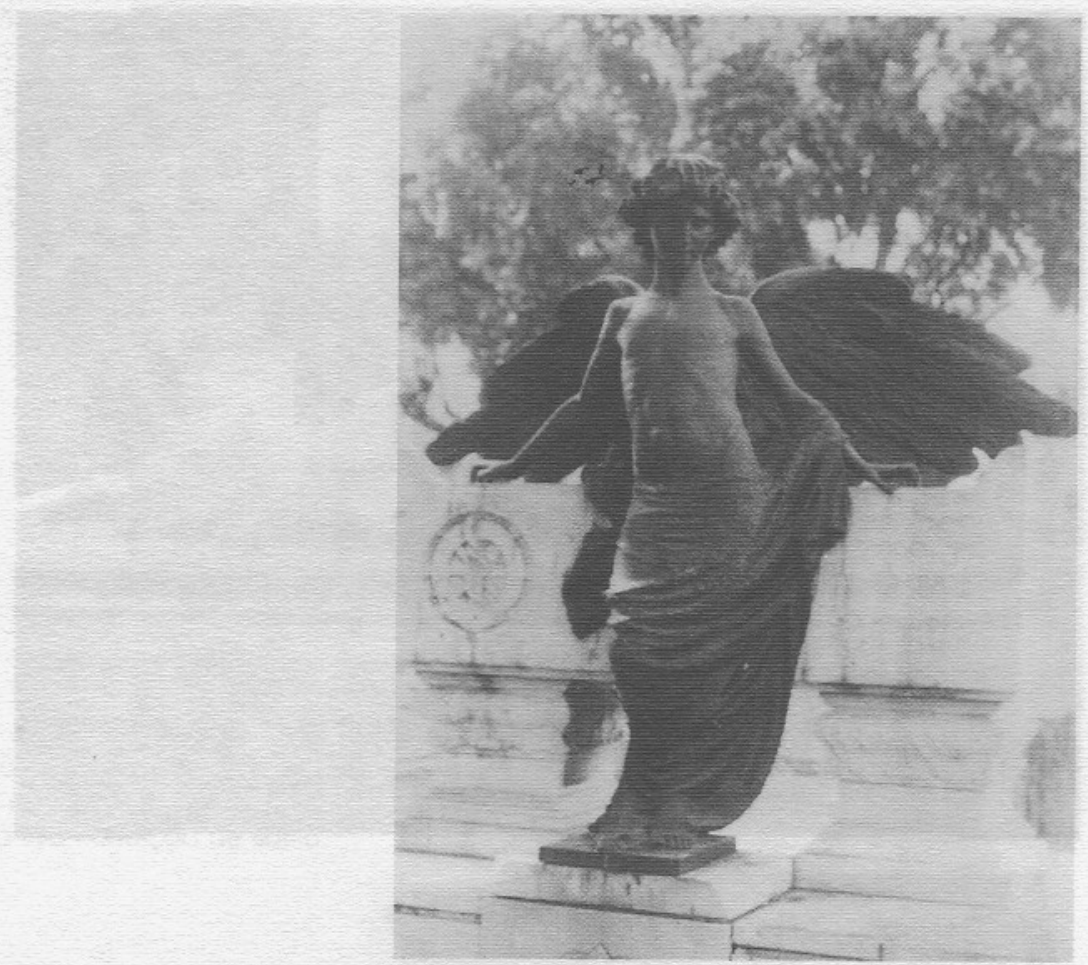

Foto 21: A penetração da cor e do erotismo nos cemitérios, à entrada do século XX: o panejamento foi colocado em seu limite extremo no corpo sensual deste grande anjo negro, datado de 1907 (Cemitério do Całumbi).

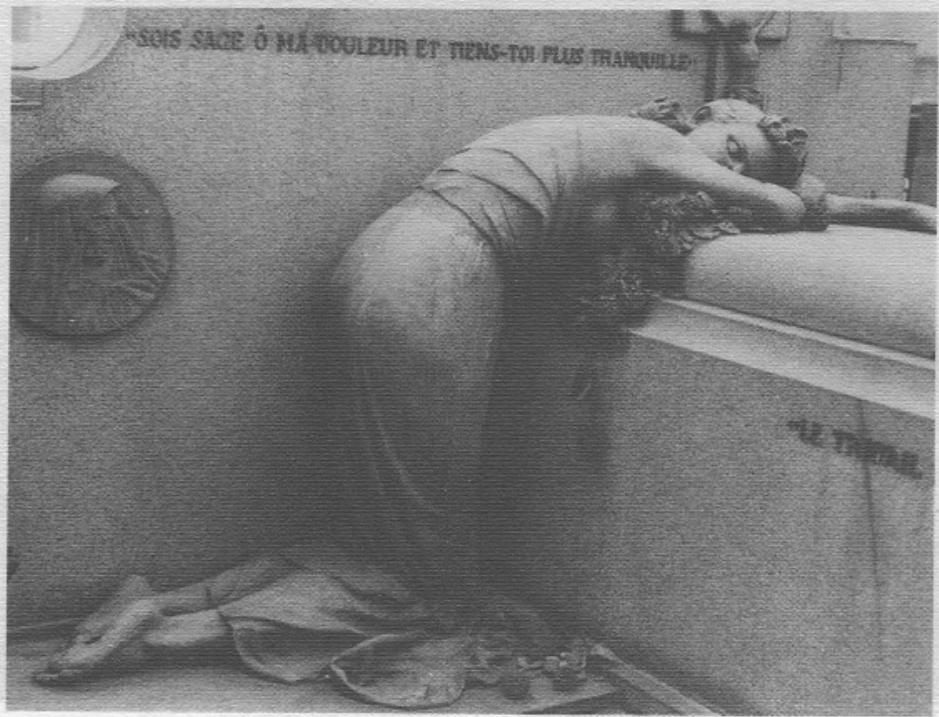

Foto 22: Uma viúva inconsolável se prostra em desespero ante o túmulo de seu marido. Descalça, suas vestes caídas deixam-na parcialmente despida; seu seio à mostra misturase às flores desarrumadas, que caem em desalinho e esparramamse pelo chão, expondo sem pudor a dimensão da sua perda (Cemitério do Caju). 

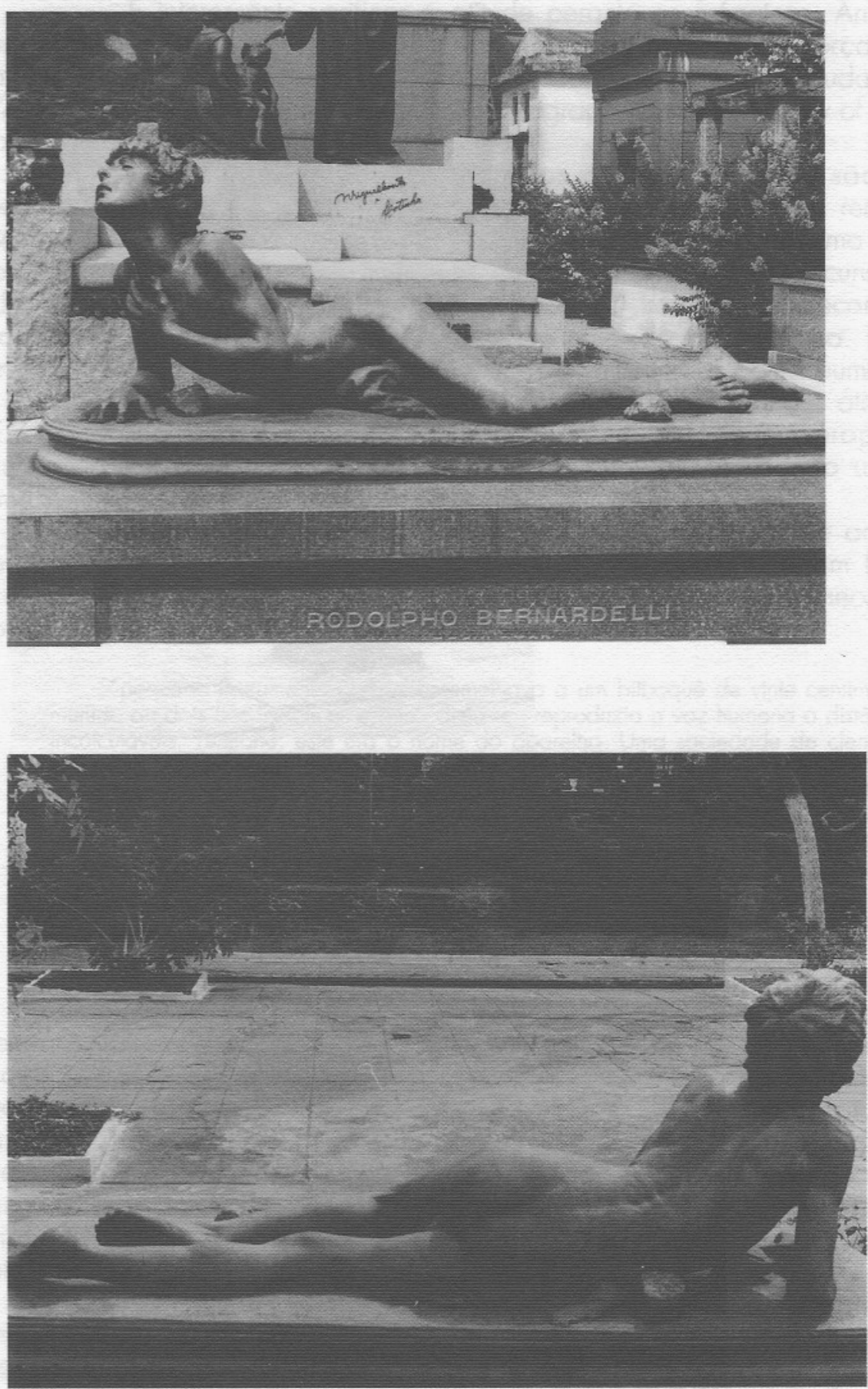

Fotos 23 e 24: Representação de Santo Estevão no túmulo de Rodolfo Bernardelli, Cemitério São João Batista: a sensualidade e a expressão de êxtase desta imagem deixam o espectador aturdido. 


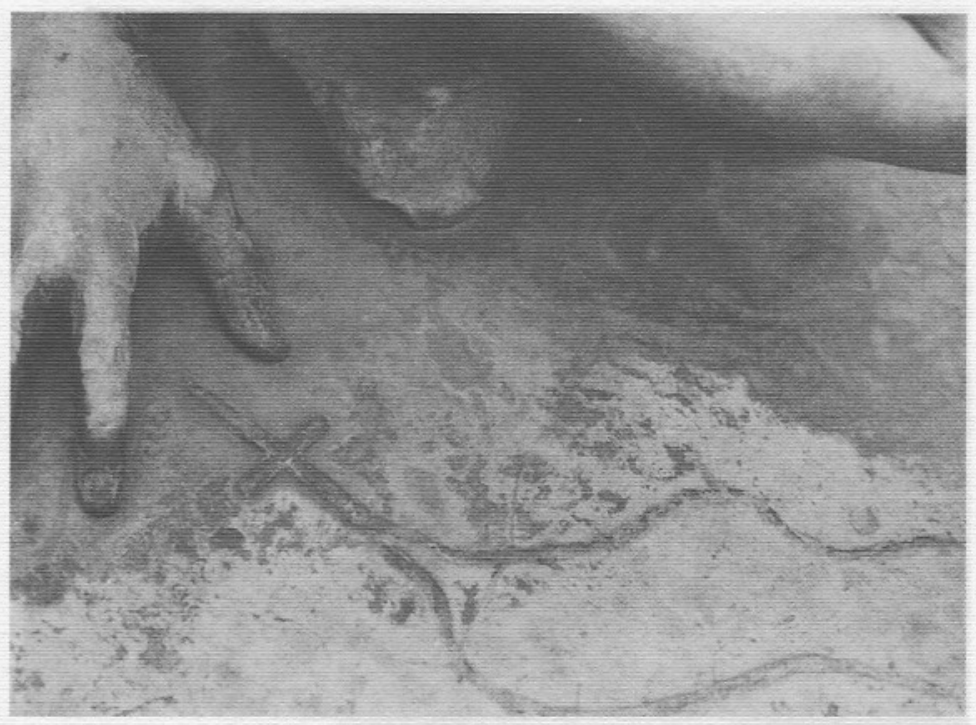

Foto 25: Como únicos atributos de santidade na representação de Santo Estevão, uma auréola (recentemente arrancada) e um terço junto à mão pousada na lápide tentam dissipar eventuais dúvidas quanto à sua condição de santo.

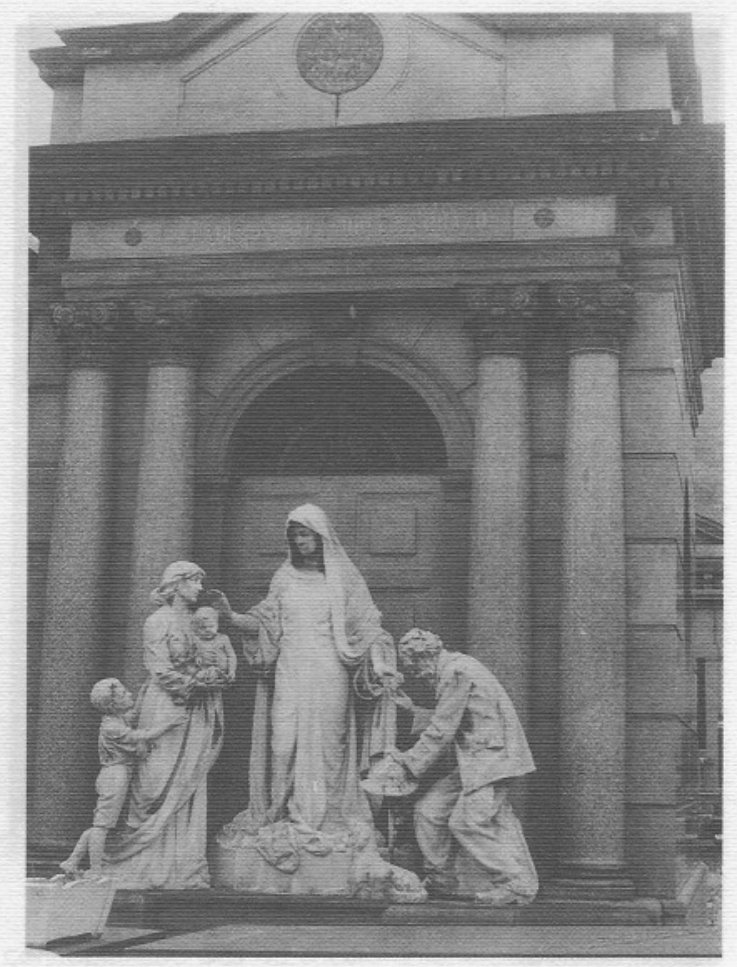

Foto 26: Mausoléu de Clarisse Indio do Brasil, no Cemitério de São João Batista. Esta rica senhora, que tinha por hábito sair à noite distribuindo esmolas entre mendigos, morreu assassinada por um deles. A sua sepultura sintetiza e perpetua, em uma cena, a sua vida. 


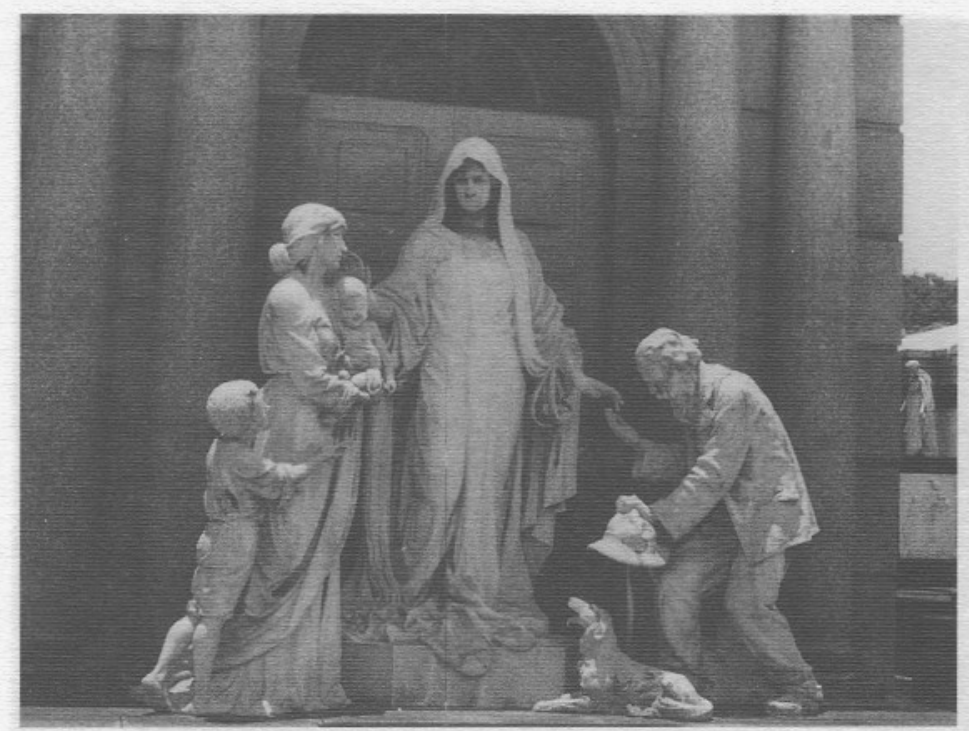

Foto 27: Em tamanho maior que o natural, a filantropa é representada simplesmente vestida, como uma madona. Colocada em um plano mais elevado, tem aos seus pés os mendigos e padecentes maltrapilhos a quem socorria.

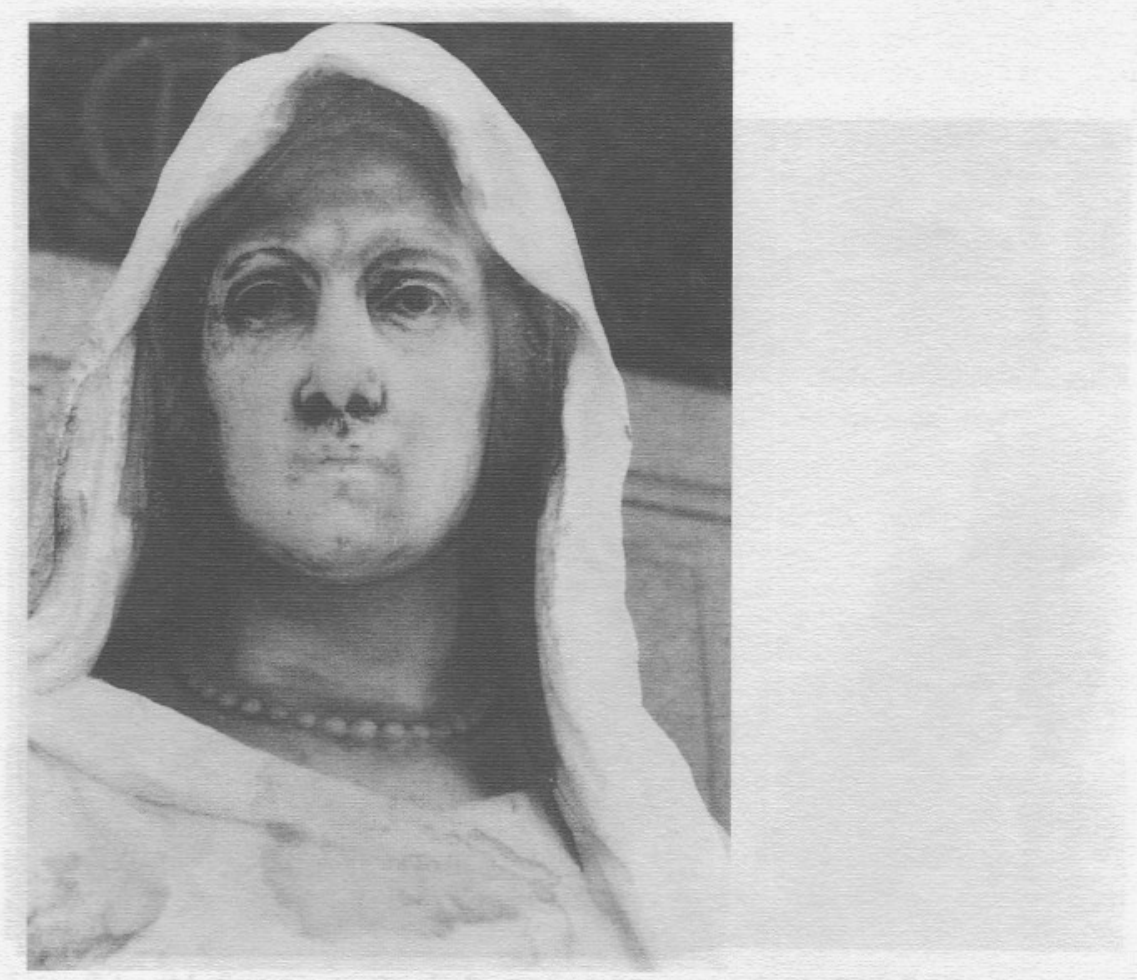

Foto 28: Entretanto, de modo a não deixar nenhuma dúvida quanto à sua condição social, a santa senhora porta um colar de pérolas, símbolo da burguesia à qual pertencia. 


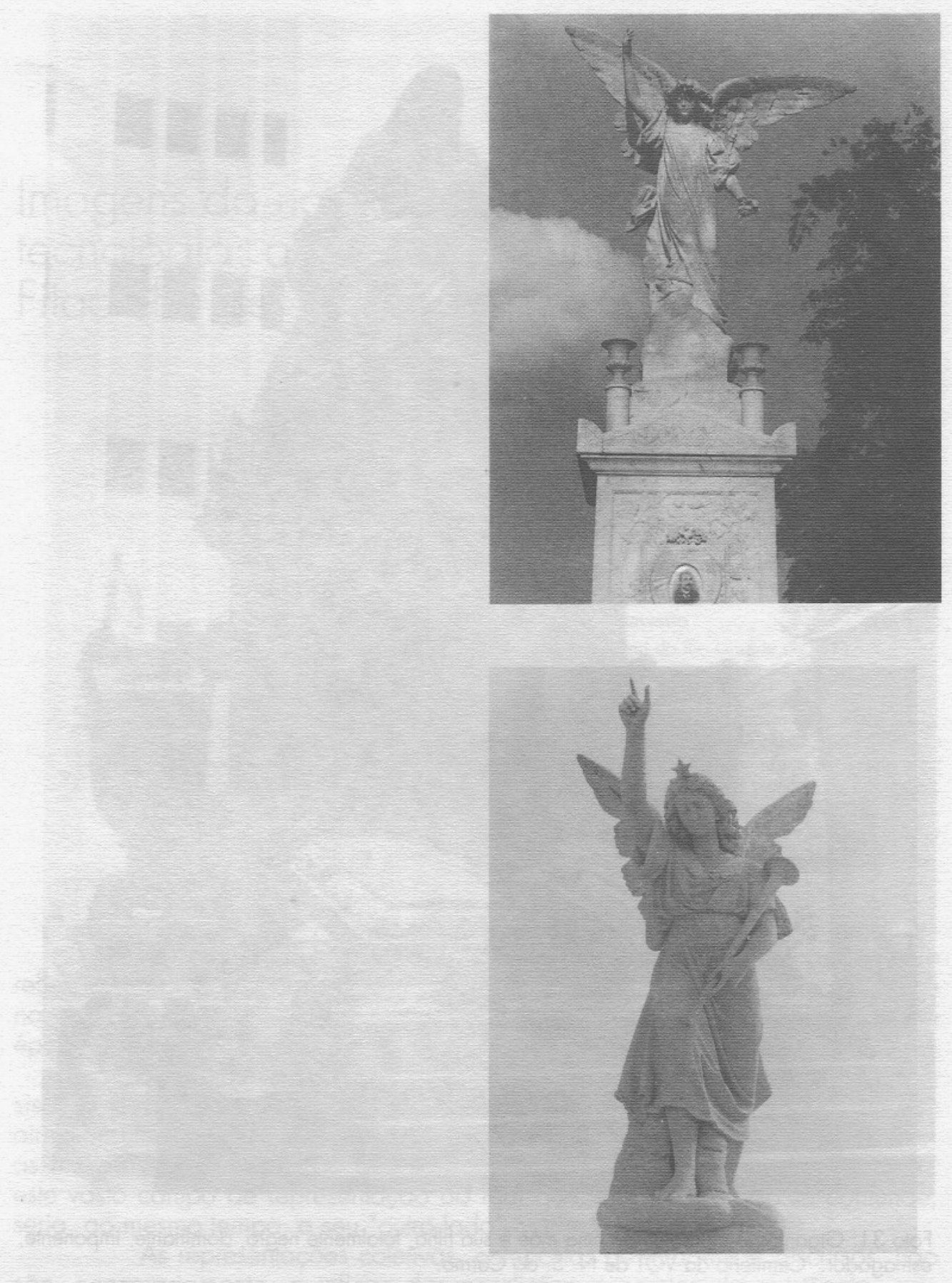

Fotos 29 e 30: Os anjos do século XX, em contraposição aos do século anterior, apontam para o alto, estrela à testa. As asas, antes fechadas e pendidas, agora estão abertas e erguidas. Suas mãos, em lugar das tochas anteriores, voltadas para baixo, portam trombetas, voltadas para cima. Cemitérios São João Batista (acima) e do Caju (abaixo). 


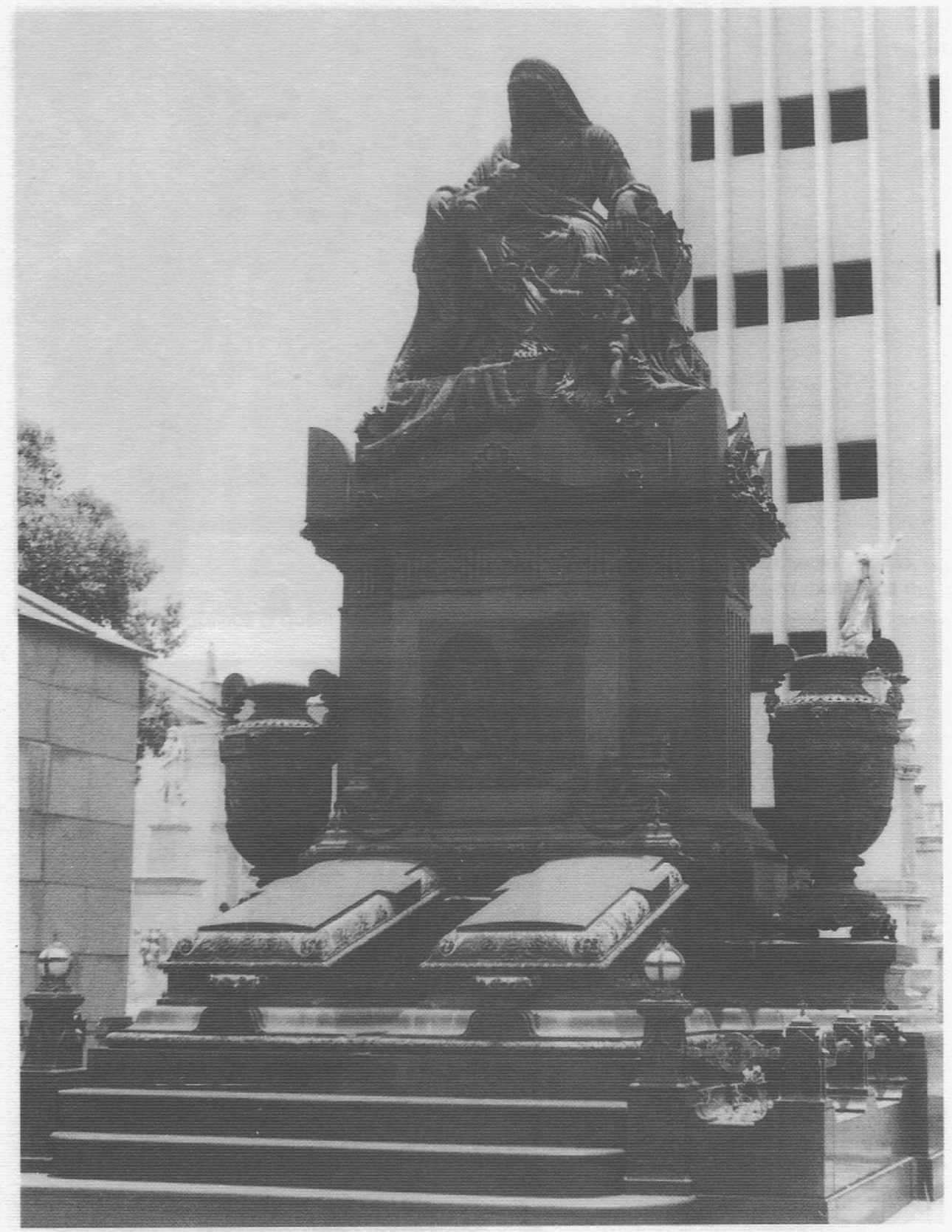

Foto 31: Gigantesco mausoléu de uma mãe e sua filha, totalmente negro, dominante, imponente, esmagador. Cemitério da VOT de N. S. do Carmo. 


\section{RESUMOS / ABSTRACTS}

Do Teatro da Memória ao Laboratório da História: a exposição museológica e o conhecimento histórico

Ulpiano T. Bezerra de Meneses

O texto procura discutir as condições de produção e apropriação do conhecimento histórico a partir do momento em que o museu deixa de aceitar como seus objetivos a evocaçāo ou celebração do passado. São examinadas diversas premissas, na perspectiva dos conceitos da cultura material: o papel insubstituivel das coleçães e a necessidade de definir problemas históricos como balizas; a construçāo social do objeto histórico, diversa da construção epistemológica do documento histórico; a retórica da exposição museológica e o uso fetichista, metonímico e metafórico dos objetos, etc. A encenação histórica ("living museums"), a contextualização museológica, as instalações, etc., são criticamente analisadas, apontando-se seus benefícios, riscos e danos (com especial atenção são tratados o paradigma observacional de conhecimento e o realismo ingênvol. A seguir, consideram-se as implicações da História como um processo cognitivo discursivo, enfatizando-se a necessidade de se fixarem responsabilidades metodológicas para os museus históricos /como produzir entendimento histórico por intermédio dos objetos; como entender a sociedade na sua mobilização de objetos em sua busca de auto-imagem e inteligibilidade).

UNITERMOS; Museu histórico. Museu e conhecimento histórico. Exposição histórica. Objeto histórico. Encenação histórica Anais do Museu Paulista: N.Ser. v.2, 1994.

From the Theater of Memory to the Laboratory of History: museum exhibits and historical knowledge Ulpiano T. Bezerra de Meneses

The paper aims at discussing conditions for the production and appropriation of historical knowt edge, once a museum denies evocation and/or celebration of the past as its legitimate purposes. Several premises are surveyed within the general framework of material culture concepts: the irreplaceble role of collections and the need of establishing historical problems as basic guidelines; the social construction of the historical object as distinguished from the epistemological construction of the historical document; the rhetorics of museum exhibits and the fetishist, metonymic and metaphoric uses of objects etc. Living museums, museological contextualizations, installations etc. are critically analysed and their benefits, risks and mischiets assessed (special attention is assigned to the observational paradigm of knowledge and the biases of a naif realism). Implications of History as a discursive cognitive process are then considered, emphasizing the importance of setting up methodological responsabilities for historical museums (how to produce historical under standing through objects; how to understand society as it searches intelligibility and auto-image through objects).

UNITERMS: History museum. Museum and historical knowledge. History exhibits. Historic

object. Living museum.

Anais do Museu Paulista: N.Ser. v.2, 1994.

De morcegos e caveiras a cruzes e livros: a representação da morte nos cemitérios cariocas do século XIX

Tania Andrade Lima

Considerando que os espaços destinados aos mortos em uma sociedade refletem especularmente - mundo dos vivos, sendo ambos regidos pela mesma lógica de organização, os cemitérios foram entendidos como um lugar de reprodução simbólica do universo social, e, nessa condição, como um campo privilegiado para a análise do processo de implantação e consolidação dos valores burgueses na sociedade carioca do século passado.

O presente trabalho, considerando a ruptura do império escravista, na década de 1880, e a emergência de uma república progressivamente capitalista, voltou-se para a verificação de prováveis mudanças no imaginário coletivo sobre a morte, nos cemitérios do Rio de Janeiro, provocadas pelo rompimento da ordem escravocrata. Uma pesquisa foi conduzida no sentido de 
se investigar não apenas a natureza dessa mudança, mas sobretudo os mecanismos subjacentes que a determinaram, sendo aqui apresentados os seus resultados.

UNITERMOS: Cemitérios. Imaginário funerário. Rio de Janeiro oitocentista. Emergência da sociedade burguesa.

Anais do Museu Paulista: N.Ser. v. 2, 1994.

From bats and death's heads to crosses and books: the representation of death at 19th-century cemeteries in Rio de Janeiro

Tania Andrade Lima

Following the assumption that spaces alloted to the dead specularly reflect the world of the living, both of them under the rules of the same logics, the A. considers the cemeteries as the locus of the symbolic reproduction of social universe and, henceforth, as a favoured domain to infer the processes through which bourgeois values are introduced and strengthened in 19th-century Rio de aneiro's society. Within the framework of the disruption of the proslavery state, in the 1880s, as well as of the emergence of a growing capitalistic republic, she detects eventual changes of the collective imaginaire concerning death, at Rio's cemeteries. The results of her fieldwork are discussed, related not only to the nature of changes, but also to the underlying mechanisms that provoked them.

UNITERMS: Cemeteries. Funerary imaginaire. 19th-century Rio de Janeiro. Emergence of bourgeois society. Anais do Museu Paulista: N.Ser. v. 2, 1994.

Imagens da nação, do progresso, da tecnologia: a Exposição Universal de Filadélfia de 1876

Sandra Jatahy Pesavento

Após considerar premissas sobre as imagens como representações sociais e sobre as Exposições Universais como um teatro privilegiado para a exibição daquela hermenêutica do real engendrada pela transformação capitalista do mundo e pelo ideário burguês, incluindo ainda a dimensão utópica da época, a A. brevemente caracteriza a Exposição do Centenário Ida Independência Americanal, na Filadélfia, 1876. Comenta a presença de um pavilhão brasileiro e os ecos da visita do Imperador D.Pedro II. Enfim, confronta sentidos divergentes, quer se trate da auto-imagem de sucesso do "sonho americano", quer das contradições de uma identidade brasileira que tenta incorporar a nova ética do trabalho livre mecanizado, numa sociedade escravocrata e vinculada ao mercado internacional.

UNITERMOS: Exposições universais. Exposição do Centenário (Filadélfia, 1876). Exposição universal e identidade brasileira.

Anais do Museu Paulista: N.Ser. v.2, 1994.

Images of the nation, progress and technology: the World Exposition of Philadelphia 1876

Sandra Jatahy Pesavento

After laying down her assumptions on images as social representations and on World's Fairs as a privileged scene for displaying the hermeneutics of reality engendered by the capitalist transformation of the world, along with the bourgeois ideology and the utopian longings of the epoch, the A. briefly describes the main features of Philadelphia's Centennial Exposition in 1876. She then comments the presence of a Brazilian pavillion and the visit of Brazil's Emperor, D. Pedro Il. She finally traces a parallel between divergent meanings of the Exhibition as related to the successful autoimage of the "American dream" in opposition to the contradictions of Brazilian identity, vainly endeavouring to incorporate the new ethics of free mechanical labour in a dependent proslavery sociely.

UNITERMS: World Expositions. Centennial Exposition (Philadelphia, 1876). World Expositions and Brazilian identity. Anais do Museu Paulista: N.Ser. v.2, 1994 